\title{
(2) norden
}

\section{Perspectives for sustainable development of Nordic aquaculture}

The Paban-Report
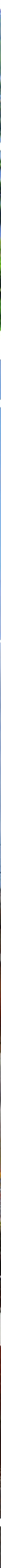

4 norden 



\section{Perspectives for sustainable development of Nordic aquaculture}

The Paban-Report

Rosten Trond W., Poulsen Helge, Alanära Anders, Eskelinen Unto, Bergsson Arnljótur Bjarki and Olafsen Trude

TemaNord 2013:546 
Perspectives for sustainable development of Nordic aquaculture

The Paban-Report

Rosten Trond W., Poulsen Helge, Alanära Anders, Eskelinen Unto, Bergsson Arnljótur Bjarki and Olafsen Trude

ISBN 978-92-893-2571-4

http://dx.doi.org/10.6027/TN2013-546

TemaNord 2013:546

(C) Nordic Council of Ministers 2013

Layout: Hanne Lebech

Cover photo: ImageSelect

Copies: 166

Print: Rosendahls-Schultz Grafisk

Printed in Denmark

This publication has been published with financial support by the Nordic Council of Ministers. However, the contents of this publication do not necessarily reflect the views, policies or recommendations of the Nordic Council of Ministers.

www.norden.org/en/publications

\section{Nordic co-operation}

Nordic co-operation is one of the world's most extensive forms of regional collaboration, involving Denmark, Finland, Iceland, Norway, Sweden, and the Faroe Islands, Greenland, and Åland.

Nordic co-operation has firm traditions in politics, the economy, and culture. It plays an important role in European and international collaboration, and aims at creating a strong Nordic community in a strong Europe.

Nordic co-operation seeks to safeguard Nordic and regional interests and principles in the global community. Common Nordic values help the region solidify its position as one of the world's most innovative and competitive.

Nordic Council of Ministers

Ved Stranden 18

DK-1061 Copenhagen K

Phone (+45) 33960200

www.norden.org 


\section{Content}

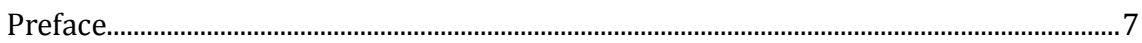

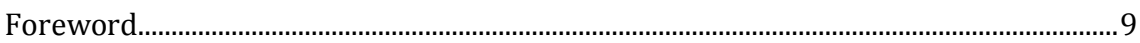

Executive summary ................................................................................................. 11

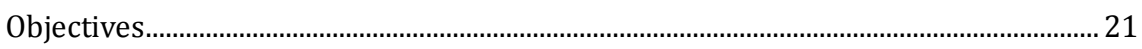

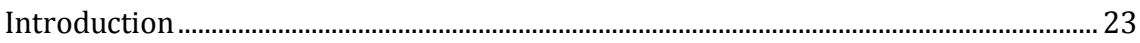

1. Perspectives for further development of sustainable aquaculture ......................... 41

1.1 P1 - Adaptations for the future shortage of the existing marine

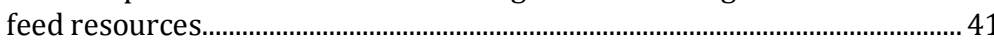

1.2 P2 - Adaptations for a sustainable use and reuse of carbon, phosphorous and nitrogen........................................................................... 46

1.3 P3 - Adaptations for creating added value based upon utilization of by-products............................................................................................................ 53

$1.4 \quad \mathrm{P} 4$ - Technology development to maximise aquaculture potential by removing major constraints for viable growth......................................... 59

1.5 P5 - Boosting the competiveness in Nordic areas attractive for aquaculture

1.6 P6 - Domestication of new species to meet increased demand for seafood production from Nordic aquaculture....................................................... 69

$1.7 \quad$ P7 - Adaptation for a lower energy use in Nordic aquaculture...................... 73

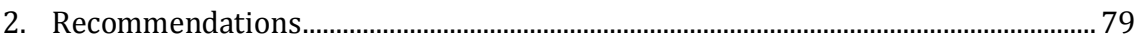

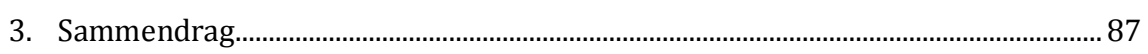

3.1 Anbefalinger fra arbeidsgruppen ................................................................. 90

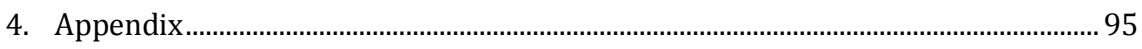

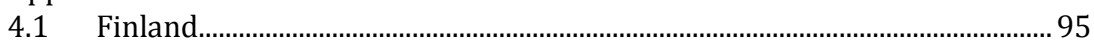

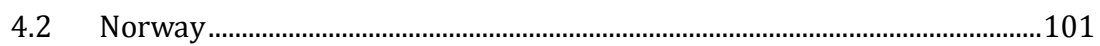

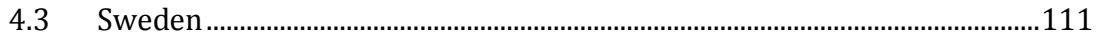

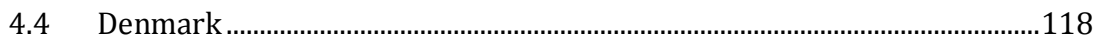

4.5 The Faroe Islands ..................................................................................... 127

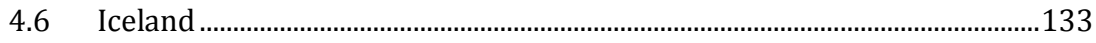





\section{Preface}

While the responsibility fisheries and aquaculture rests within the Nordic Council with a dedicated working group (EK-Fisk) under the Ministerial Council for Fisheries, Agriculture, Forestry and Nutrition (FJLS), this working group also strives to extend its cooperation to other working groups under the umbrella of Nordic Council of Ministers. One of these groups is the Working Group on Sustainable Development (The BU-group). This group decided in 2011 to focus attention on sustainable development at sea - and more specifically on aquaculture. The practical implication of this decision was that a large share of the BU 2012 budget was set aside for assisting the Fisheries cooperation to prepare a working document with a sustainability perspective, which could fit into a Nordic discussion on how to develop the aquaculture sector. This support from the NCM Group on Sustainable Development is highly appreciated.

The background for this report has been the Rio+ 20 conference, organized in early June 2012, with its emphasis on the need to improve global food production in oceans and coastal areas. Another part of the backdrop is the "green growth" and bioeconomy strategies of the Nordic Council of Ministers. Aquaculture can contribute significantly to global food security, and also provides for income opportunities and export revenues. On the other hand it is recognized that further growth in this sector entails important challenges in keeping with ambitions to ensure that such a development is consistent with the green growth concept.

Aquaculture is an important industry for the Nordic countries, particularly for Norway and the Faroe Islands, but other Nordic countries are also looking at their potential to develop aquaculture industry. Aquaculture was an important topic under the Finnish chairmanship of the Nordic Council of Ministers (NCM) in 2011, when a large conference on aquaculture in the Baltic Sea was organized in Helsinki. This report is a follow-up by the Norwegian NCM 2012 chairmanship to the Helsinki conference, widening the scope to cover the entire Nordic region.

An overarching regional perspective on aquaculture development in the Nordic region is applied in this report. The document is based on the analyses and discussion of a Nordic working group which has identified the potential for growth, common constraints, and major regional differ- 
ences in the aquaculture industry. The outcome of this process is structured into seven different perspectives on aquaculture growth in the Nordic region.

This report was initially prepared as a background document to the Nordic ministerial meeting in Trondheim in late June 2012, where it proved to be a useful input to the conference on green growth in the marine sector. It has also served as a background for the so called" Nidarosdeclaration" - "On the responsibility of the primary sectors and food industry for green growth." The declaration was adopted in the ministerial meeting. In the time to come, this report will also serve as a useful reference document for implementation of the Nidarosdeclaration, in the development of a Nordic Bioeconomy Strategy, and further collaboration on sustainable aquaculture within the framework of the Nordic Fisheries Cooperation.

On behalf of the Nordic Fisheries Cooperation I would like to thank the project team, and their team leder Mr. Trond Rosten for this timely, interesting and very useful report.

Oslo 18 December 2012

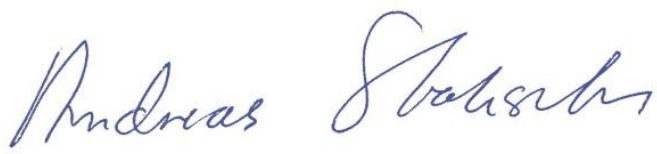

Andreas Stokseth

Senior Adviser to the Norwegian

Ministry of Fisheries and Coastal Affairs,

and Chairman for the Nordic Working Group

on Fisheries and Aquaculture 2012 


\section{Foreword}

On behalf of the project group I would like to thank Nordic Council of Ministers for the opportunity to discuss the challenging but exciting theme of perspectives for green development of Nordic aquaculture. We hope that this report will give some directions on how to safeguard a sustainable development of Nordic aquaculture and pave some ground for green development ideas.

A lot of people have contributed to this report, but I would like to especially thank Andreas Stokseth, Ásmundur Guðjonsson, and the reference group; Geir Oddsson, Martin Bryde, Jóanna Djurhuus, Pôl Edvard Egholm, Johan Anderson Anell and Orian Bondestam for their contributions throughout the project.

Trondheim 5 April 2013

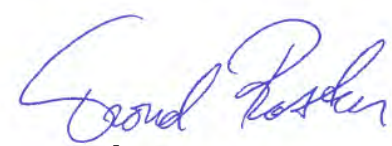

Trond W. Rosten 



\section{Executive summary}

During 2012, a Nordic working group consisting of experts from the Technical University of Denmark (DTU), Swedish University of Agricultural Sciences (SLU), Finnish Game and Fisheries Research Institute (RKTI), Matis Ltd, SINTEF Fisheries and Aquaculture (SINTEF) discussed and came up with 7 proposed perspectives (P1-P7) on green growth for aquaculture in the Nordic countries:

P1 Adaptations for the future shortage of the existing marine feed resources.

P2 Adaptations for a more sustainable use and reuse of carbon, phosphorous and nitrogen.

P3 Adaptations for creating added value based upon utilization of by-products.

P4 Technology development to maximise aquaculture potential by removing major constraints for viable growth.

P5 Boosting the competiveness in Nordic areas attractive for aquaculture.

P6 Domestication of new species to meet increased demand for seafood production from Nordic aquaculture.

P7 Adaptation for a lower energy use in Nordic aquaculture.

The report has been produced in collaboration with a reference group appointed by the Council of Ministers for Fisheries and Aquaculture, Agriculture, Food and Forestry (MR-FJLS). The work was presented at the conference Nordic Green Growth in June 2012 (http://www. greengrowthnordic.no /). The report is based on the discussions of the expert group, review and analysis of official statistics, industry reports and scientific publications, and direct input administrated through the reference group. The individual perspectives (P1-P7) are described in detail in the report. The perspectives are generally placed in a thirty year horizon. A brief overview of the important aspects of each perspective is presented below. The recommendations from the working group follow thereafter. 


\section{P1 Adaptations for the future shortage of the existing marine feed resources}

Marine feed ingredients are a limited resource and the demand for fishmeal and fish oil in particular is increasing. From a green growth perspective, wild fish stocks must be managed sustainably. If Nordic aquaculture is to grow, alternative feed sources need to be developed. There are several challenges for the use of non marine protein and oil sources, both in terms of energy balance, quality of feed, performance (fish health and growth), and quality of the final product. An underlying question is the cost of using or developing new feed sources for aquacultured fish. The working group do not believe it is likely that farming of plant-eating fish species (herbivores) will develop in the Nordic countries, but believes that research and development will enable greater use of feed resources from residual materials, vegetables, microbial or plankton. Better utilization of residual materials from fisheries may also contribute to green growth. There is already a good knowledge platform in the Nordic countries in research on feed for the current farmed species and the working group sees that it is important to build upon this.

\section{P2 Adaptations for a more sustainable use and reuse of carbon, phosphorous and nitrogen}

There are opportunities for green growth by utilizing the resources available in sludge from aquaculture. The carbon can be utilized for biogas production and the nutrients as fertilizer or soil improvement. The working group directs special attention to the fact that phosphorus is a limited global resource and therefore should be recycled where possible. As other animal food productions, there will be sludge and dissolved nutrient produced from fish farming proportional to the feed distrubuted to the animals. To what extent this discharge acts to improve or degrade the aquatic environment depends on local conditions. From a Nordic perspective there are different challenges in the different aquaculture areas in terms of the effects of emissions of nitrogen and phosphorus. This may have implications both for local adaptation in the regulatory regimes and for the choice of technology.

\section{P3 Adaptations for creating added value based upon utilization of by-products}

Large quantities of wild and farmed fish are landed and produced in the Nordic countries. Most of the by-products from marine origin are utilized today, but the working group argues that further green growth can be made possible on the basis of these large streams of biomass. Advanced processing combined with market development 
may provide opportunities for new products in a range of different markets. Increased utilization of by-products is closely related to adaptations in perspective 1 , where the challenge of limited marine feed resources is noted.

\section{P4 Technology development to maximise aquaculture potential by removing major constraints for viable growth}

There is great potential for aquaculture in the Nordic area. A further development of the aquaculture sector must be based on the regional environmental challenges addressed, including problems with wild salmon in western Scandinavia and eutrophication in the eastern and southern part of Scandinavia. Salmonides will, if not alone, constitute the major biomass in the Nordic aquaculture platform in a 30-year scenario and it is important to facilitate research and development on a Nordic level to safeguard this. The working group conclude that technological and biological knowledge is greatest for salmonid species and the likelihood of developing new technology solutions for the remaining environmental challenges will be biggest for these.

\section{P5 Boosting the competiveness in Nordic areas attractive for aquaculture}

There is a significant need for measures to strengthen the competitiveness of the Nordic areas attractive for aquaculture. There are various measures that must be applied in different areas depending on the factors that prevent growth and development. The report points to specific actions for the Nordic countries to meet such regional challenges (see recommendations). The working group believes that the Nordic aquaculture can be significantly enhanced by facilitating the transfer of governance experience from areas with a mature aquaculture sector to areas where such sector management are still under development.

\section{P6 Domestication of new species to meet increased demand for seafood production from Nordic aquaculture}

Future aquaculture in the Nordic countries is expected to revolve largely around the farming of salmonid species such as; Atlantic salmon, rainbow trout and Arctic charr. Out of these, only Atlantic salmon and rainbow trout are considered fully domesticated and industrialised. It is clear to the working group that the Arctic charr has good potential to be the third industrialised species, but the working group recommends a joint Nordic effort to develop at least two species to an industrialized level. One of them should be a whitefish. In a future 30 year scenario, there will also be room for a number of niche species, but these will con- 
tribute to a smaller degree to the production of large biomasses that are important to green growth.

\section{P7 Adaptation for a lower energy use in Nordic aquaculture}

Information available on the energy consumption and carbon footprint in aquaculture is largely based on farming of Atlantic salmon the traditional Norwegian way. It will be necessary to analyze the carbon footprint in other farmed species and with different technology solutions. In comparative studies, farmed Atlantic salmon have a better carbon footprint than pork and beef, but slightly higher than pelagic fish. Most of the carbon footprint stems from the fish feed, so with the increased use of alternative feed resources for protein or oil, one should examine these in terms of their effect on the climate impact. In a future scenario we expect that the energy used in transport to end markets will decline, as a cause of a higher refining degree prior to packing and shipping. New technology for freezing and packing will also affect climate impact as more efficient transport, longer shelf life and reduced wreck of edible products are expected.

\section{Recommendations from the working group}

In the following the most important recommendations for developing green growth in Nordic aquaculture are presented. To see a more bulletpointed presentation, see chapter "Recommendations" later in the report.

\section{Reputation of the aquaculture sector}

First and foremost, aquaculture in the Nordic countries must be recognized as an important and necessary industry for sustainable food production. The effort to establish a positive reputation for this industry, should take place on a Nordic level since there are many synergies and similarities between the countries. The aquaculture industry should expect to be treated equally with other primary food production industries. A somewhat weak reputation of the aquaculture industry seems to be a mutual problem in the Nordic countries and this is likely to affect recruitment and opportunities for future development. Strong opportunities for green growth in this sector are identified, but the Nordic countries must work on adaptations around the seven perspectives (P1-P7) for them to be fulfilled. 


\section{Feed Resources a key factor}

A policy for adaptation of aquaculture to projected limited marine feed resources must be implemented. Fish oil and fishmeal are now the main ingredients in fish feed, but these resources are under increasing utilization pressure, financially in the form of rising prices and political in terms of increased focus on the protection of marine ecosystems. A scenario where more of these resources are directly used for human consumption is foreseen. Increased harvesting of resources at lower trophic levels in the food chain, e.g. microalgae, krill and calanus might be interesting as feed resources. Stimulation of research and development necessary for increased use of by-products and agricultural products in the fish feed is vital. Measures to support the development of new sources of feed e.g. from kelp, yeast and bacteria are highly recommended.

\section{See nutrient rich and nutrient poor areas in context}

The majority of biomass production from aquaculture is still expected to occur in the seas of Norway, Faroe Islands and Iceland. Even so, the Nordic countries can implement measures to enable the development of inland and land-based aquaculture, and farming in the Baltic Sea. A political acceptance of the ecosystem service principle of moving nutrients from nutrient-rich (eutrophic) areas (such as the Baltic Sea) to nutrient poor (oligotrophic) water bodies (such as hydroelectric dams) using fishfarms is important. Stimuli for feed production based on planktoneating fish from the Baltic Sea will possibly increase opportunities for ecosystem services from fish farming. Through such measures it is possible to achieve positive ecosystem effects both for the Baltic Sea and nutrient-poor inland lakes.

\section{Opportunities between green and blue sector}

A new and exciting opportunity for sustainable growth is to link production cycles from green and blue sectors by encouraging research and development for the production of protein to fish feed using microorganisms on the basis of waste products from the paper industry. The potential to produce feed for more than 1 Mtons of fish has been communicated to the workgroup.

The impending global inorganic phosphorus deficiency must be given greater attention in a green growth aquaculture context. Policies and measures that can help to ensure increased capture and reuse of phosphorus from discharges of aquaculture will make the Nordic countries pioneers in this field. Adaptations for better use and collection of phosphorus are recommended in all food production and consumption systems. It is important for their reputation that the aquaculture industry 
also contributes. It is predicted that it might be possible to recover phosphorus and nitrogen from aquaculture by including the harvesting of natural populations of kelp, mussels, benthic or actively cultivate these in relation to breeding areas (so called "catch crop"). If one succeeded in developing marine floating closed aquaculture, it would probably be possible to establish systems for particle capture that facilitate the recovery of even more phosphorus and carbon.

Sludge captured and collected from land-based fish farming represents a new opportunity for green growth. This resource contains large amounts of carbon and nutrients (including phosphorous) which is attractive for the production of biofuels and fertilizers, and possible even more advanced products. Policies and stimuli to develop systems for logistics and production of biogas and products from fish sludge are recommended. This represents an opportunity where blue and green sectors can be better linked. Incorporation of fish sludge in manure prior to biogas production is a promising techinique. Increased utilization of the byproduct from biogas production to fertilizer is a also good resource utilization.

\section{By-products - basis for a new industry}

The potential for green growth based on the huge biomass coming from fisheries and aquaculture is large. Opportunities to develop more advanced products based on their by-products are foreseen. To facilitate such development, policies and measures for innovation and business development should be stimulated. This can be the overriding priority through instruments such as NordForsk and Nordic Innovation. Utilization of by-products for the production of food (health food, functional food), pharmaceutical products and ingredients for both feed and food (protein, fats, minerals) will increase the value of the fish and the industry and is likely to contribute to a better reputation. The Working Group believes that new industries can be developed in this field and thus set the standard for other farming areas in the world.

\section{Technology}

To exploit the full potential of aquaculture in the Nordic countries, there is a need for development of both new and existing technologies suitable for production in marine, freshwater and landbased systems. A joint Nordic research effort tailored through instruments such as NordForsk and Nordic Innovation is recommended to develop such technologies. A specific focus on off-shore aquaculture of salmon is needed to ensure a future large biomass from this production platform. Focus on the development of materials, systems and operations that can withstand more 
exposed sites, and eliminate problems with escapees and sea lice, and systems that can be used in combination with "catchcrop" e.g. algae, seaweed and mussels should be prioritized. The aquaculture industry is dependent on a sound technology base and strong supply industry for land based systems to ensure farming of the first phases of salmonids and for culturing high-paying niche species. Stimuli for Nordic cooperation in research and innovation directed towards the improvement of such systems are recommended. The focus should be on developing improved recirculation aquaculture systems (RAS), including the development of systems that have lower investment and energy costs, that enable economies of scale and have improved water treatment and capture of nutrients/carbon from the discharge. Developments for inland farming of other species e.g. charr and trout in freshwater lakes etc., should be focused towards materials, systems and operations that can withstand ice and eliminating potential problems with escapes and other potential ecosystem effects. A collaboration at the Nordic plan for the development of inland aquaculture as a good supplement for seabased aquaculture is recommended.

\section{Bet on few species}

The main biomass coming out of the Nordic aquaculture industry originates from Atlantic salmon, rainbow trout and Arctic charr. Only Atlantic salmon and rainbow trout can be said to be fully developed and industrialized, but it is likely that new species can also represent a green growth potential and hold an important key to future growth of aquaculture in the Nordic areas. In order to make this happen, there is a need for political recognition of the time and resources that is needed to domesticate a species for aquaculture. On a more general basis, we recommend that the Nordic countries jointly focus on industrialising two new species in the next thirty-year perspective. There are indications that one of these species is Arctic charr, but it is recommended that the other should be a white fish with either marine or freshwater origin. The group recognizes, and appreciates the importance of the development of niche species in addition to the main species. These can be of both marine and freshwater origin.

\section{Regional recommendations}

Food production in different Nordic regions can be enhanced by focusing on specific geographical actions. This will provide biomass that can be utilized for green development. The report suggests the following focus areas: 
- The Baltic sea

Aquaculture production can be increased by improved area planning, local supply of fish feed, simplification of regulations and by the use of catchcrops.

- Sweden and the interregional areas along the Swedish /Norwegian border

Identification and organization of freshwater lakes and rivers suited for inland farming of arctic charr and/or rainbow trout. The interregional areas sharing the same river/water system should be approached coherently. Nordic cooperation for a commercially adapted breeding program and licence policy for arctic charr is recommended.

- Denmark

It is likely that green growth can be obtained by changing the regulation regime from feed quotas to nitrogen/phosphorous quotas. This process is already started. A policy of tradable nitrogen/phosphorous quotas between agriculture and aquaculture is recommended. Measures that can increase the possibility for offshore aquaculture, integrated multitrophical aquaculture (IMTA), farming of niche species represent good opportunities.

- Finland

Stimuli for an active consolidation process gathering fish farms into fewer, larger and more functional units, operating on good sites are the most important actions. Necessary changes in the aquaculture regulations, so that the indirect negative effect on industry development is removed, should be looked into in more detail. Some possibilities for new species are foreseen.

- Iceland

Should focus on increasing the production of Arctic charr in landbased farms by utilisation of everlasting competitive advantages with geo-thermal and geo-filtered water sources. In addition focus on developing offshore aquaculture of salmon, alongside farming of new species based on the competitive advantages is recommended. 
- Norway

Should focus on utilisation of everlasting competitive advantages of suited marine water for aquaculture of salmonids. A reliable interface towards wild salmon/sea trout interactions must be established. Development of sterile salmon, offshore aquaculture, escapee free farms and systems, the use of catchcrops, a prolonged smolt phase in semi-closed systems and new solutions for salmon sea lice should pave the way for green growth.

- Faroe Islands

Should focus on utilisation of everlasting competitive advantages of suited marine water for aquaculture of salmonids. Development of off offshore aquaculture and catch crops could pave the way for green growth. A mutual strategy with Norway for solutions of threats against wild salmon and sea trout in the North Atlantic is recommended. 



\section{Objectives}

The overall goal of this project was to suggest perspectives for a green growth development of aquaculture in the Nordic countries. This was to be done by describing the status of aquaculture in the Nordic countries (including conditions and natural advantages), shed light on important common challenges, describe differences and draw up 4-6 Nordic perspective with recommendations what the political authorities can implement to facilitate development and value creation. The project was given the name PABAN (PerspektivAnalyse på videreutvikling av Bærekraftig Akvakultur i Norden), hence "The PABAN report".

We have conducted the assignment in the period from December 2011 to June 2012 by following this method:

- Establisment of a Nordic workgroup with experts from Technical University of Denmark (DTU), Swedish University of Agricultural Sciences (SLU), Finnish Game and Fisheries Research Institute (RKTI), Matís Ltd, Sintef Fisheries and Aquaculture AS (SINTEF).

- Establishment of a reference group in cooperation with Council of Ministers for Fisheries and Aquaculture, Agriculture, Food and Forestry (MR-FJLS).

- A review and analyis of official statistics, industry reports and scientific publications adressing issues within aquaculture and sustainability, 1993-2012.

- A workshop in Cobenhagen 15 and 16 December 2011, outlining the basis for the approach, report structure and perspectives ideas.

- Meeting with representatives for the Council of Ministers for Fisheries and Aquaculture.

- Prepartion of a status description and a SWOT analysis for each Nordic country amongst the workgroup members.

- Telephone meeting with workgroup with identification of areas suitable for discussions of green growth challenges in workshop nb two in Cobenhagen 13-15 March 2012. 
- Hearings with with representatives for the Council of Ministers for Fisheries and Aquaculture.

- Workshop in Cobenhagen, outling and overall descriptions of 7 perspectives on green growth of aquaculture in the Nordic countries.

- Compilations of draft report based upon material from workshop in March.

- Reviews on draft report from the reference and the workgroup members.

- Presentation of draft report on green growth conference in Trondheim 27 July 2012.

- Final report compiled March 2013. 


\section{Introduction}

Aquaculture has a long history in the Nordic countries with Danish import and production of rainbow trout in the 1920s and the Norwegian success with sea cage farming of salmon in the 1970s as important paradigm shift transforming wild fish to a domesticated animal. In a relatively short timespan, aquaculture has developed into a considerable industry for the production of food, reaching more than 1.1 million tonnes in 2010, with Atlantic salmon as the most important species. The sector is still relatively young and has the potential for further growth and development (Asche and Bjørndal 2011). The important production Nordic areas in terms of volume are the Norwegian coast, Danish inland waters and the coast of the Faroe Islands. Aquaculture is now also developing in nutrient poor (oligotrophic) freshwater basins, in the Baltic Sea and in land based recirculation systems (RAS) in several Nordic regions. The salmonids Atlantic salmon, rainbow trout and Arctic charr are currently the most important fish species in the Nordic aquaculture platform. Even if there is a bias towards the salmonids, the farming of white fleshed fish species like cod, pike pearch, halibut and turbot have also reached an acceptable level of knowledge, making them likely to play a part of the future seafood production platform, given sufficient attention. A future for non-fish species such as blue mussels and kelp are also anticipated. Blue mussel and kelp harvest industries are already established but, based on existing and new knowledge and their potential as cleaners and converters of nutrients to food or energy products, these species look very promising for further green development.

Aquaculture is one of the fastest growing food producing sectors in the world and has a potential to contribute substantially to the global food supply. It is expected that aquaculture production will play a central role in meeting the future increase in demand for fish and fish products in light of a growing population and present status of no or limited growth in the capture fisheries sector (Garcia and Rosenberg, 2010). Production of food from aquaculture is identified as a full pillar of the new reformed European Union (EU) Common Fisheries Policy (CFP) and EU strategic guidelines on common priorities and targets for the development of aquaculture activities are to be established by 2013. On this basis, member states must 
establish a multiannual national strategic plan for the development of aquaculture activities in their territories by 2014.

Aquaculture production in the Organization for Economic Cooperation and Development (OECD) and the European Union (EU) has stagnated during recent decades, with a few exceptions including Norway, Chile, Turkey and the UK. One reason for this stagnation is strict environmental regulation and bureaucracy (European Commission 2009, OECD 2010) and the wide use of command and control instruments, such as aquaculture extension moratoriums and feed quotas, to manage negative environmental externalities (Nielsen, 2012).

\section{The global challenges}

Given the global challenges described by The Millenium Project, Cordell et al. 2011a, the reports on climate change given by The Intergovernmental Panel on Climate Change (IPCC) and The Marine Board (MB) (Heip, 2011), the future development of Nordic aquaculture is going to be challenging (Figure 1). Challenges relevant for Nordic Aquaculture are:

- A global lack of phosphorous.

- A limitation of fish meal and fish oil sources.

- Increased air temperature above sea and land used for aquaculture.

- Increased frequencies and intensity of storms.

- Larger peak waves.

- Larger peak wind speeds.

- Increased rainfall and precipitation.

- Effects on trophodynamics (plankton, benthos and fish populations) and ecosystems.

- Favorable conditions for jellyfish, decapods and echinoderms.

- Increased $\mathrm{CO}_{2}$ level in air and water inducing oceanic acidification.

\section{Specific for the Baltic Sea:}

- Decreased surface salinity.

- Increased coastal erosion.

- Decreased duration of sea-ice season. 
- Increased sea temperatures $\left(+4-6{ }^{\circ} \mathrm{C}\right.$ in winter and $+3-5{ }^{\circ} \mathrm{C}$ in the summer) (She, 2011).

- Main sea level rise.

- Accelerated eutrophication due to increased precipitation and river run-off.

- Increased stratification and worsened bottom oxygen conditions.

- Reduced water transparency due to increased river run-off.

- Freshwater species and invaders from warmer seas expected to enlarge their distribution area.

\section{Climate Change}

The Nordic seas used for aquaculture extend broadly both east/west and north/south. It is expected that these ecosystems may be modified as an indirect cause of climate related challenges. In the long term it is expected that the sea temperature is increasing, but lower salinity in the Baltic Sea could also be a likely consequence. Several changes may result in complications for aquaculture (see previous list) including mowing of suitable areas for farming of Atlantic salmon northwards.

Figure 1. Global challenges (outer cyclys) defining basis for future Nordic aquaculture

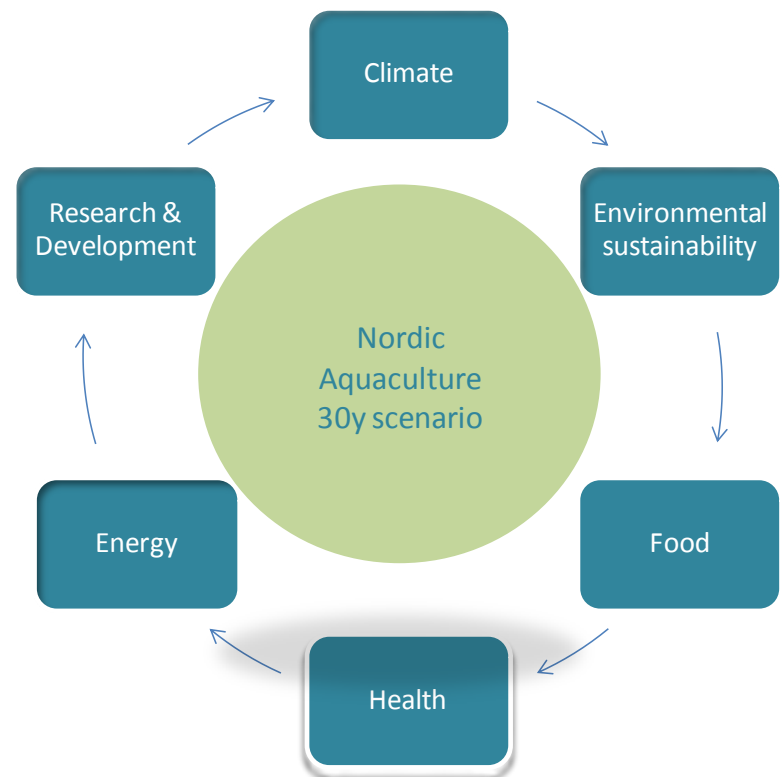




\section{Environmental sustainability}

As knowledge about sustainable exploitation of the marine resources grows it becomes apparent that productivity of food and marine based products has the potential to increase. These sources are important for the feed production in aquaculture. From a sustainability perspective, many fish stocks are under too high fishing pressure. This fact, combined with high prices and large demand of fishmeal and fish oil calls for a need to find new feed ingredient sources in aquaculture. The marine resources used to achieve feed ingredients, must originate from environmentally sustainable fisheries. Fisheries on a lower trophical level of resources such as krill or copepods (e.g. Calanus finmarchius) are expected to be important for aquaculture and new marine industries. Discharge of nutrients (nitrogen and phosphorous) and carbon gives limitations for developing aquaculture in certain Nordic areas, but is also likely to provide opportunities for the use of sludge, growing kelp and mussels for bio fuel, or producing ingredients or food. Tougher rules ensuring only accepable effects of aquaculture on wild Atlantic salmon stocks can be expected as a precondition for future development of aquaculture. A customer driven request for certification and documentation of sustainability is expected to increase. Standards set by the Aquaculture Stewardship Council, ASC and Marine Stewardship Council, MSC are expected to be the most important ones, but others may come.

\section{Food}

Passing 7 billion people in 2012, the human population on earth is expected to reach 9 billion people in 2050. A large proportion of this increase is expected to occur in developing countries where the numbers of slum dwellers are high. More than $10 \%$ of the population of the earth is undernourished and crops have failed in many countries as recent as 2010. In this scenario FAO has predicted that the global food production needs to increase by $70 \%$ within 2050 . It is not likely that food produced by aquaculture in the Nordic countries will be a food source for the undernourished in developing countries, but we can contribute significantly in the total global production of fish. It is expected that Nordic seafood will be important to cover the demand from an increasing middle class in many countries including Europe and the BRIC-countries (Brasil, Russia, India, and China). It is also recconized that one of the most important things the Nordic countries can contribute with is transfer of knowledge to countries that are in the process of developing their aquaculture production (lessons lernt both by the fish farmers and by the authorities). 


\section{Health}

The WHO has stated that cardiovascular diseases and obesity are currently and in the future the most important cause of reduced life quality or early death in industrialised countries. An increase of fish in the diet is recommended by the FAO/WHO due to the documented positive health effects of marine fatty acids like EPA and DHA. The content of these marine oils in aquacultured fish are reflected by the level of these oils in the feed. A surprisingly a large proportion of people still choose unhealthy alternatives to seafood, and this is challenge for product development and marketing. Since EPA/DHA sources currently are limited and have multiple applications the content of these marine fatty acids in aquacultured fish are under pressure. New production technology and new sources (algae, Calanus and krill) will be important.

\section{Energy}

Global consumption of energy will continue to grow. Despite increased focus on renewable energy; we expect that the main sources of energy in 2050 will still be fossil fuels. The proportion coming from biofuel could increase from $3 \%$ to $27 \%$ in 2050 according to the IPCC. This gives new opportunities for the aquaculture industry to increase their scope by production of kelp as a biofuel in integrated multitrophical setups utilizing nutrients from fish production (for example see Rosten et al, 2011). Utilization of collected sludge form land based fish farms as a carbon source for bio-fuel production provides an even more direct link between aquaculture and energy consumption. Better usage of energy resources, by combining production is also an oportunity. Combinations of food production through aquaculture in relation to renewable hydroelectric power plants/dams and geo-thermal sources, are examples of such actions.

\section{Economy and trade}

Europe is the most important market for seafood from the Nordic countries. Currently there is an ongoing economic crisis in Euro-zone with an imbalance between strong (e.g. Germany, France) and weaker economies (e.g. Greece, Portugal, Spain and Italy) forcing governments to budget cuts. These may affect private economies negatively and affect the food market. It is expected that other important markets such as USA and Japan will have modest economic growth, while the economies within the BRIC countries and other countries outside the OECD are expected 
to grow most in the near future and that this could change the demand for fish (Dørum, 2012).

Looking into the future, economic crises and the consequences of uncertainty and chaos is maybe the biggest wildcard - and very difficult to predict. Periods with economic crises will come and affect the stability of the society and peoples buying power.

\section{Research and Development}

The increasing rate in research and development (R\&D) and the globalization of knowledge and capital offers opportunities and challenges in business development. Given access to capital and knowledge, new aquatic businesses could develop at great speed. Along with classical technical and engineering sciences, enabling technologies like biotechnology, nano-technology, and information- and communication technology are likely to be both foundation and drivers for a rapid development of new businesses based upon aquatic resources, related to aquaculture directly or indirectly. The Nordic countries have a strong postion within $R \& D$ and efforts should be taken to withold this position. As examples of R\&D topics with potential high impact on Nordic aquaculture we mention the production of food from non-food sources via the use microorganisms like zygomycetes, and development of new systems enabling offshore aquaculture.

\section{Towards a green development in Nordic aquaculture}

The last decades there has been different processes leading up to definitions of a sustainable development. The first and most important definition was made by the the World Commission on Environment and Development (WCED), the Brundtland Commission, in the main report Our Common Future, (1987). Sustainable development is defined as development that "meets the needs of the present without compromising the ability of future generations to meet their own needs". A Sustainable development ties together concern for the carrying capacity of natural systems with the social challenges faced by humanity (Figure 2). 


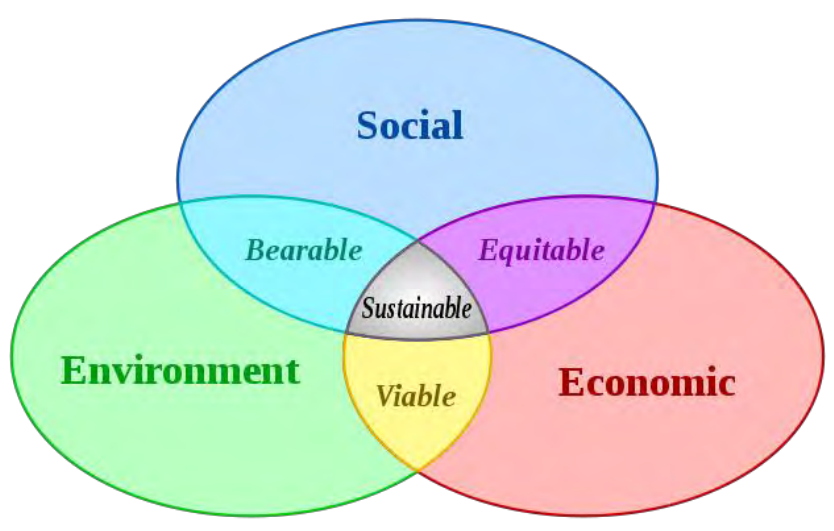

In 1997 two American scientists, Juan Enriquez and Rodrigo Martinez, used for the first time the word "bioeconomy" at a meeting in American Association for the Advancement of Science. After this, several attempts in defining "biobased economy" have been made. In our context we have chosen a defintion from a EU-report ${ }^{1}$ : a low waste production chain starting from the use of land and sea, through the transformation and production of bio-based products adapted to the requirements of endusers. More precisely, a bio-based economy integrates the full range of natural and renewable biological resources - land and sea resources, biodiversity and biological materials (plant, animal and microbial), through to the processing and the consumption of these bio-resources. The bio-economy encompasses the agriculture, forestry, fisheries, food and biotechnology sectors, as well as a wide range of industrial sectors (6), ranging from the production of energy and chemicals to building and transport. It comprises a broad range of generic and specific technological solutions (already available or still to be developed) which could be applied across these sectors to enable growth and sustainable development, for example in terms of food security and requirements for industrial material for future generations.

\footnotetext{
${ }^{1}$ Bio-based economy in Europe: state of play and future potential - Part 2. Summary of the position papers received in response of the European Commission's Public on-line consultation. Published by DirectorateGeneral for Research and Innovation Food, Agriculture \& Fisheries, \& Biotechnology, 2011.
} 
The term green growth has been used to describe national or international strategies for achieving sustainable development. In the last five years the green growth perpecitive has been introduced in the Nordic countries. It is focusing on overhauling the economy in a way that synergizes economic growth and environmental protection, building a green economy in which investments in resource savings as well as sustainable management of natural capital are drivers of growth. OECD has recently published a strategy towards a global green growth ${ }^{2}$ and the Nordic Council of Ministers has also done work on the green growth perspective. ${ }^{3}$ The primeministers of the Nordic countries have identified that the Nordic area should take on a leading role in terms of green growth (Nordisk ministerråd, 2011).

Sustainable development, biobased economy and green growth strategies are all concepts that intervene with each other and there might be a a need for clearing up the interfaces, but in this report we focus on a 30 years perspectives on how to develope Nordic Aquaculture in a green growth approach.

\section{How can we develope aquaculture with a green growth perspective?}

OECD has discussed this topic in an ongoing project (OECD, 2011). Developing aquaculture needs to be balanced and address concerns such as the use of feed fish, pollution, transmission of fish diseases, escapees and competition for space. The Nordic Council of Ministers places a high priority on green growth and in 2010 the Nordic prime ministers agreed to make green growth a index for the Nordic countries future inter-governmental cooperation (Nordisk ministerråd, 2011). Following the definition brought forward by the OECD (2011a), green growth means "fostering economic growth and development while ensuring that natural assets continue to provide the resources and environmental services on which our well-being relies" (OECD, 2011a). For the aquaculture industry an interpretation (OECD) of green growth could mean finding a way to accommodate increasing production while the addressing the major concerns; Feed, Escapees, Discharges, Diseases and Space (FEDDS) (Table 1).

\footnotetext{
2 Inclusive green growth: for the future we want. Oecd work of relevance to Rio+20 June 2012.

${ }^{3}$ Nordic Council of Ministers. Green Growth for Nordic Prosperity.
} 
Table 1. Concerns ("FEDDS") needing to be addressed in aquaculture development. Adapted from (OECD) by discussion within the workgroup

\begin{tabular}{ll}
\hline Concerns & Comment \\
\hline Feed & Lack of fishmeal and fish oil for further expansion \\
Escapements & Potential genetic and ecological impact on wild stocks \\
Discharges & $\begin{array}{l}\text { Loss of resources like carbon, nitrogen and phosphorus into the local ecosystem, with } \\
\text { potential for negative effects }\end{array}$ \\
Diseases & $\begin{array}{l}\text { Diseases on fish farms may be transferred to other farms or the wild fish or vice versa } \\
\text { Space }\end{array}$ \\
& $\begin{array}{l}\text { Competition for space with other users, both recreational and commercial. One important } \\
\text { aspect is the impact the use of space (aquaculture site structure) can have on the conse- } \\
\text { quences of escapes, discharges and diseases). For example, how the sites are located in } \\
\text { relation to other site, elements one wants to protect (for example salmon river/spanning } \\
\text { ground for cod) and other commercial activity (for example discharges from agriculture) may } \\
\text { have consequences for the total environmental footprint of the aquaculture activity }\end{array}$ \\
\hline
\end{tabular}

The issues listed above must be addressed to achieve green growth development within aquaculture. The variables to control within each overarching issue (each of the FEDDS) need to be broken down and then addressed with measures within a policy framework (Table 2).

Table 2. Green Growth Challenges, variables to control, policy framework and measures

\begin{tabular}{|c|c|c|c|}
\hline $\begin{array}{l}\text { Green Growth } \\
\text { Challenges }\end{array}$ & Variables to control & Policy framework & Example measures \\
\hline Feed & $\begin{array}{l}\text { Feed fish resources } \\
\text { International trade }\end{array}$ & $\begin{array}{l}\text { Research priorities } \\
\text { Regulations for the use of GMP and } \\
\text { by-products in fish feed } \\
\text { Innovations }\end{array}$ & $\begin{array}{l}\text { Use non-food and vegatatible } \\
\text { sources for feed production, } \\
\text { better utilization of raw- } \\
\text { material, ban on discards }\end{array}$ \\
\hline Escapees & $\begin{array}{l}\text { Weather and natural forces } \\
\text { (waves, current, wind, ice) } \\
\text { Large scale operations with } \\
\text { heavy equipment } \\
\text { Accidents }\end{array}$ & $\begin{array}{l}\text { Research priorities } \\
\text { Regulations } \\
\text { Management practice }\end{array}$ & $\begin{array}{l}\text { Technology and operation } \\
\text { improvements } \\
\text { Sterilization, Tagging, Shift in } \\
\text { production plans (larger smolts } \\
\text { - fewer days in sea) } \\
\text { Paying local fishermen to catch } \\
\text { the escapees }\end{array}$ \\
\hline Diseases & $\begin{array}{l}\text { Current and new diseases } \\
\text { Density }\end{array}$ & $\begin{array}{l}\text { Research priorities } \\
\text { Regulations } \\
\text { Good management practices }\end{array}$ & $\begin{array}{l}\text { Vaccine, Fallowing, knowledge } \\
\text { about sea currents, quarantine }\end{array}$ \\
\hline Discharges & $\begin{array}{l}\text { Production and end pipe } \\
\text { technology (EPT), Feed, Feed } \\
\text { conversion rate, Feed } \\
\text { composition }\end{array}$ & $\begin{array}{l}\text { Technology adaptations and inno- } \\
\text { vation Regulations } \\
\text { Management practice }\end{array}$ & $\begin{array}{l}\text { MTB or feed quotas, site } \\
\text { selection, fallowing, IMTA } \\
\text { (kelp and mussels), logistics } \\
\text { for collection and further } \\
\text { production and use }\end{array}$ \\
\hline Space & $\begin{array}{l}\text { User conflicts / } \\
\text { conflicting uses } \\
\text { Development Planning }\end{array}$ & $\begin{array}{l}\text { Permits and zoning, Environmental } \\
\text { approvals, Investment aids, Coastal } \\
\text { zone/ ocean management }\end{array}$ & $\begin{array}{l}\text { Select sites (criterias) with } \\
\text { lowest environmental foot- } \\
\text { print }\end{array}$ \\
\hline
\end{tabular}

Partly based upon OECD (2012) but adapted with views of the PABAN workgroup. 


\section{Aquaculture in the Nordic countries}

Aquaculture in the Nordic countries has developed into an important industry for food production. Production has grown massively during the last 30 years and reached more than 1.1 billion $\mathrm{kg}^{4}$ in 2010 according to latest FAO statistics. Production is dominated by Norway $(90 \%$ of total) (see Table 3) and growth of the industry has mainly occurred there. In fact, production has reduced in Finland and Iceland in recent years. Important production areas are shown in Figure 3.

Figur 3. Important production areas for aquaculture in the Nordic countries

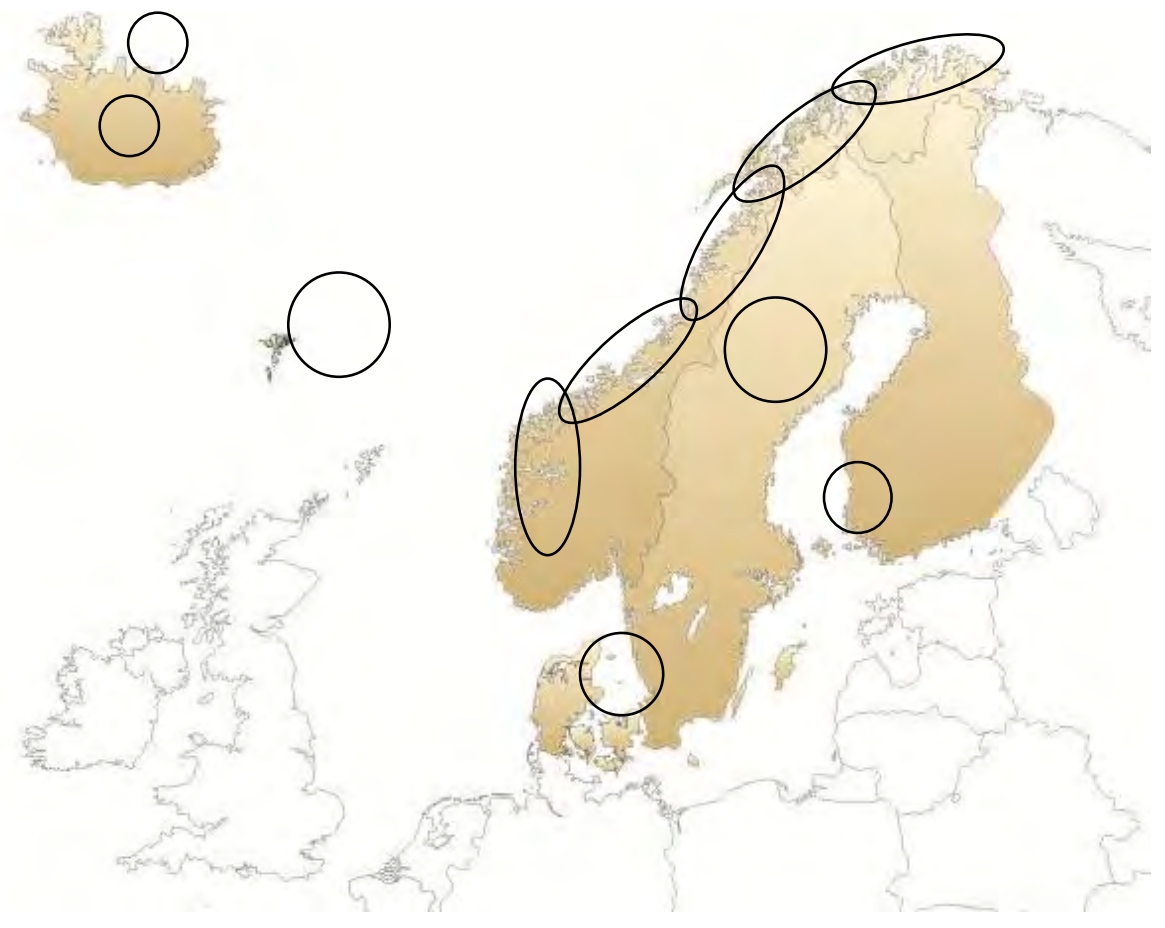

${ }^{4}$ Equals million tonnes. 
Table 3. Aquaculture production by country

\begin{tabular}{lr}
\hline Country & Total Aquaculture production (Mtons) \\
\hline Norway & $1,008,010$ \\
Faroe Island & 47,575 \\
Denmark & 39,507 \\
Finland & 11,772 \\
Sweden & 10,644 \\
Iceland & 5,050 \\
\hline
\end{tabular}

Adapted from FAO 2010.

\section{Brief overview of each country}

\section{Norway}

Aquaculture in Norway is dominated by the farming of Atlantic salmon. Current fish farming technology involves landbased (coastal) production of juveniles in tank systems fed by gravity, pumps or recirculation aquaculture systems (RAS) supplied water, discharged filtered or unfiltered into the sea. Ongrowing takes place at sea in large scale, open, netbased cages with floaters in PolyEthylene (PE) or steel in sites producing 1,200-14,000 Mtons. Centralised large scale harvesting and processing plants enable well established logistics for live fish and finished products. A breeding program for Atlantic salmon and trout has been established for more than 20 generations of fish. Inland aquaculture has not yet developed into a viable business. Other species farmed are minor to Atlantic salmon but include rainbow trout, cod, halibut, turbot, blue mussel, Arctic charr, lobster and spotted wolffish.

\section{Sweden}

Sweden is dominated by the farming of rainbow trout and Arctic charr and blue mussels. The current fish farming technology involves landbased production of juveniles in tanks systems fed by pumps, gravity or RAS supplied water, discharged filtered or unfiltered into the sea or water systems. Ongrowing takes place in sea or freshwater systems with open netbased cages with floaters in PE or steel in sites producing from 25-2,000 Mtons. Aquaculture consists of more locally scattered smaller scale harvesting and processing plants and relatively small scale logistical operations due to the small volumes. There is growing interest in establishing Arctic charr farming using oligotrophic freshwater systems. A breeding program for Arctic charr has been established and runned for seven generation fish. Other farmed species of less economical importance are includes perch, eel and crayfish. 


\section{Finland}

Finland is dominated by the farming of rainbow trout and the production of roe. Current fish farming technology involves landbased production of fry in systems fed by gravity, pumps or RAS supplied water, or natural food ponds. Discharge is released filtered or unfiltered into freshwater systems or the sea. Ongrowing takes place at sea in small scale, open, netbased cages with floaters in PE or steel in sites producing 30-350 Mtons. Production is harvested in locally scattered, smaller scale harvesting and processing plants. There is a relatively small scale logistical operation due to the small volumes. There is growing interest in establishing white fish and pikeperch as new freshwater species. Other farmed species of less economical importance include trout, Arctic charr, perch, sturgeon, grayling and crayfish.

\section{Denmark}

Denmark has a varied aquaculture production, but is dominated by the farming of rainbow trout and roe. The current fish farming technology involves landbased production of fry in systems fed by pumps or RAS supplied water. Discharges are filtered into freshwater systems or the sea and sludge collected from filters is and sediments are in most cases, used as compost. Ongrowing takes place in landbased raceways of lined earthponds, concrete constructions, and circular tanks, or at sea in netbased cages with floaters in PE or steel. Farming sites produce about 502,000 Mtons with locally scattered, smaller scale harvesting and processing plants. Denmark represents a knowledge cluster for RAS systems in the Nordic countries. There is growing interest for establishing pike pearch as new freshwater species and Atlantic salmon in landbased RAS systems. Production of other species is small compared to rainbow trout but include eel, blue mussels, pike-perch, perch, white fish, turbot, Arctic charr other salmonids and several other species.

\section{The Faroe Islands}

The Faroe Islands are dominated by the production of Atlantic salmon. The current technology involves land based (coastal) production of smolts in tank systems fed by gravity, pumps or mainly RAS supplied water, and discharges are released filtered or unfiltered into the sea. Ongrowing takes place at sea in large scale, open, net based cages with floaters in PE or steel in sites producing 1,200-7,000 Mtons. Centralised large scale harvesting and processing plants are well developed as well as well established logistics for live fish and finished products. Aquaculture in the Faroe Islands has been known for the sucess of renewed production layout after major disease problems in the 1990s to currently 
having the lowest sea mortality rates. (Hjeltnes et al., 2012). The market is dominated by only four large companies.

\section{Iceland}

Iceland is dominated by the production of Arctic charr (Charr). Charr are produced in landbased farms supplied with geothermal water presented by flow-through system, gravity fed or pumped. On-growing of charr takes place in large scale concrete tanks originally designed for salmon production in the 1990s. Salmon and cod are produced at sea (fjord) in open net based cages with floaters in PE or steel. Charr and salmon sites produce around 200-1,000 Mtons. Production is harvested in locally scattered, smaller scale facilities and processing plants withrelatively small scale logistical operation due to the small volumes. There is growing interest for establishing aquaculture with hot water species like sole and tilapia in land based systems. Other species minor to charr include Atlantic salmon, Atlantic cod, halibut, turbot, tilapia, blue mussel and Senegal sole. For a more detailed description of each country we refer to appendix 1 .

\section{Current competitive position}

To take on future growth in Nordic aquaculture requires an understanding of the current competive postion. Key questions in such an approach are; what are our advantages? How easy is it to facilitate a sustainable future growth? What are the obsticles for viable development? We have, through dicussions within the workgroup and input from our reference group, produced twelve characteristics for the current competitive position. We have used the terms Competitive Challenge (CC), Competitive Advantage (CA) in our evaluation. The evaluation is shown in Table 4 but must be seen in relation to the SWOT analysis presented in Table 5. As shown in Table 4, the current position might be regarded as weak. There is however a lot that can be done in terms of policies and measures to improve the position. We refer to the identified perspectives presented later in this report. 


\begin{tabular}{|c|c|c|}
\hline $\begin{array}{l}\text { Non prioritized } \\
\text { number }\end{array}$ & Description & $\begin{array}{l}\mathrm{CC}=\text { Competitive Challenge, } \\
\mathrm{CA}=\text { Competitive Advantage }\end{array}$ \\
\hline 1. & $\begin{array}{l}\text { Large areas suitable for aquaculture and relatively close } \\
\text { to the most important markets (EU) }\end{array}$ & CA \\
\hline 2 & $\begin{array}{l}\text { Cap on growth in the largest production area due to } \\
\text { environmental challenges affecting wild salmon. }\end{array}$ & $\mathrm{CC}$ \\
\hline 3 & Cap on growth in east due to regulations. & $\mathrm{CC}$ \\
\hline 4 & $\begin{array}{l}\text { Cap on growth in south due to feed quotas / discharge } \\
\text { limits of nitrogen. }\end{array}$ & $\mathrm{CC}$ \\
\hline 5 & $\begin{array}{l}\text { Cap on growth in west due to limited access to protect- } \\
\text { ed areas. }\end{array}$ & CC \\
\hline 6 & $\begin{array}{l}\text { A (limited) potential for growth in middle by use of } \\
\text { hydro electrical poer dams. }\end{array}$ & $\mathrm{CC}$ and $\mathrm{CA}$ \\
\hline 7 & A (limited) potential for growth in the Faroe Islands. & $\mathrm{CC}$ and $\mathrm{CA}$ \\
\hline 8 & $\begin{array}{l}\text { Weaknesses in regulatory systems for aquaculture } \\
\text { reported from Finland, Sweden and Denmark. }\end{array}$ & CC \\
\hline 9 & $\begin{array}{l}\text { Investors "locked" inside salmon business because it is } \\
\text { proven to be profitable. }\end{array}$ & $\mathrm{CC}$ \\
\hline 10 & Lack of competence and people (outside salmon business). & CC \\
\hline 11 & Image problem of industry (except maybe Faroe Island). & CC \\
\hline 12 & $\begin{array}{l}\text { A public (not always knowledge based) opinion arguing } \\
\text { for a forced technology shift to high cost production } \\
\text { systems and species. }\end{array}$ & CC \\
\hline
\end{tabular}

Based upon discussions during the Paban workshop in Copenhagen.

\section{The Nordic SWOT}

A condensed analysis of strengths, weaknesses, oportunities and threats in terms of aquaculture development in the Nordic countries was conducted on the basis of the status description done for each country. The result is given in Tables $5 \mathrm{a}-\mathrm{d}$. 


\begin{tabular}{|c|c|}
\hline Country & Strengths \\
\hline \multirow{4}{*}{ Finland } & Strong local domestic products \\
\hline & Good fish health situation \\
\hline & Production of trout roe is viable \\
\hline & Good infrastructure \\
\hline \multirow[t]{4}{*}{ Iceland } & Success with Artic charr \\
\hline & Warm and cold water resources \\
\hline & Good potential for sea farming in the Westfjords \\
\hline & Absence of most serious diseases \\
\hline \multirow[t]{4}{*}{ Denmark } & Strong tradition of trout production \\
\hline & High conciousness of product quality \\
\hline & RAS technology well developed (equipment supply) \\
\hline & Leading in feed production \\
\hline \multirow[t]{5}{*}{ Faroe Islands } & Ideal environmental location for salmon farming \\
\hline & Efficient law and regulations \\
\hline & High priority in national economy \\
\hline & Good image of the industry \\
\hline & Good fish health \\
\hline \multirow{5}{*}{ Sweden } & Huge freshwater resources \\
\hline & Many modified waters with reduced ecological value (hydroelectric power dams) \\
\hline & could be used for aquaculture \\
\hline & Good potential for sea farming in the Gulf of Bothnia \\
\hline & Breeding program for arctic charr \\
\hline \multirow[t]{6}{*}{ Norway } & Salmon farming established as a viable business \\
\hline & Efficient law and regulations \\
\hline & Natural conditions for netbased culture of salmonid \\
\hline & Knowledge and education \\
\hline & Capital available in salmon business \\
\hline & One of Norways strongest industrial clusters (Reve \& Sasson, 2012) \\
\hline
\end{tabular}

Table 5b. Weaknesses identified for each Nordic country in terms of aquaculture development

\begin{tabular}{ll}
\hline Country & Weaknesses \\
\hline Finland & Small production units \\
& Short growing period \\
& Low profitability \\
& Ageing of producers \\
& One species dominance \\
Iceland & Limited recruitment \\
& Low diversification of products \\
& Variable profitability highly influenced by fluctuating market price \\
& Conflicts with local authorities \\
Many small units \\
Henmark
\end{tabular}




\begin{tabular}{|c|c|}
\hline Sweden & $\begin{array}{l}\text { Poor knowledge base within the whole value chain from farmers to politicians } \\
\text { Lack of education (practical training and university level) } \\
\text { Lack of investors and financing }\end{array}$ \\
\hline Norway & $\begin{array}{l}\text { Conceited position as production leader? } \\
\text { Difficult to get new licences } \\
\text { Salmon dependent business } \\
\text { Environmental challenges } \\
\text { Recruitment (Reve \& Sasson, 2012) }\end{array}$ \\
\hline Country & Opportunities \\
\hline Finland & $\begin{array}{l}\text { Spatial planning the key for bigger production units } \\
\text { Developing new species } \\
\text { Value added products } \\
\text { Using the Baltic blend principle }\end{array}$ \\
\hline Iceland & $\begin{array}{l}\text { Optimize favorable and stable environmental conditions } \\
\text { Direct use of geothermal energy } \\
\text { Utilizations of by-products } \\
\text { Create jobs in rural areas }\end{array}$ \\
\hline Denmark & $\begin{array}{l}\text { Strategic alliances focusing on the whole value chain } \\
\text { Improve image in relation to environment and sustainability } \\
\text { Development and sale of environmental friendly technology (RAS) } \\
\text { Certification of production methods }\end{array}$ \\
\hline Faroe Islands & $\begin{array}{l}\text { Improve utilization of farming areas and expand to the furthest reaches of the fjords. } \\
\text { Improve transport and logistics } \\
\text { More valueadded products and introduce new species } \\
\text { Utilize discharge for IMTA and Bio-Fuel } \\
\text { Expand production areas at sea }\end{array}$ \\
\hline Sweden & $\begin{array}{l}\text { Create jobs in rural areas } \\
\text { Locally produced food } \\
\text { Synergetic effects with sport fishing } \\
\text { Ecosystem services in hydroelectric power dams and The Robin Hood principle }\end{array}$ \\
\hline Norway & $\begin{array}{l}\text { Use the knowledge base and industrial experience to expand both the salmon sector and } \\
\text { other species } \\
\text { Develop industrial aquaculture as a knowledge hub, attractive for ownership, } \\
\text { knowledge, R\&D, industrial clusters, environment and talents and education } \\
\text { New technologies for removing risk and effects of escaped fish } \\
\text { Utilize offshore knowledge for industry building } \\
\text { More value added products } \\
\text { Create jobs and activity in rural areas } \\
\text { Utilize discharge for IMTA and Bio-FuEel }\end{array}$ \\
\hline
\end{tabular}


Table 5d. Threats identified for each Nordic country in terms of aquaculture development

\begin{tabular}{ll}
\hline Country & Threats \\
\hline Finland & $\begin{array}{l}\text { Lack of coordination of policy between sectors/e.g. environmental and licensing } \\
\text { policy } \\
\text { Global market situation } \\
\text { Diseases }\end{array}$ \\
Increasing production cost \\
Public resistance \\
Diseases \\
Environmental degradation \\
Non-competitiveness on price and quality \\
Lack of labour force. Problems in recruitment and generation shifts \\
Environment criteria set that cannot be fulfilled \\
Finance \\
High cost economy \\
Expansion possibilities are limited unless ocean farming is successfull \\
Disease outbreak \\
Competition (mainly from Nordic countries) \\
Access to water \\
Public resistance \\
Environmental degradation (euthrophication, diseases and spread of unwanted genes) \\
Environmental challenges affecting wild Atlantic salmon (low attractivness acording \\
to Reve \& Sasser 2012) \\
High cost economy \\
Diseases \\
Attractiveness in education and for talents (Reve \& Sasser, 2012) \\
Norway
\end{tabular}





\section{Perspectives for further development of sustainable aquaculture}

Through a combination of desktop studies of peer reviewed literature and reports, presentations by members of each institution ${ }^{5}$ and discussion in two PABAN workshops the working group has produced seven Nordic perspectives relevant for a green growth approach in aquaculture. These perspectives represent the areas/ideas where the PABAN working group recommends focusing when establishing policys and measures. The perspectives are discussed in a thirty year time span, sometimes pointing even further into the future. The perspectives were named during the second workshop, exept perspective 7 which was applied after comments from the reference group. Titles are presented below in Table 6, and dicussed in the following chapters.

Table 6. Perspectives for green growth in the Nordic Aquaculture Industry

\begin{tabular}{ll}
\hline Nb & Perspective \\
\hline P1 & Adaptations for the future shortage of the existing marine feed resources \\
P2 & Adaptations for a more sustainable use and reuse of carbon, phosphorous and nitrogen \\
P3 & Adaptations for creating added value based upon utilization of by-products \\
P4 & Technology development to maximise aquaculture potential by removing major constraints for viable growth \\
P5 & Boosting the competiveness in Nordic areas attractive for aquaculture \\
P6 & Domestication of new species to meet increased demand for seafood production from Nordic aquaculture \\
P7 & Adaptation for a lower energy use in Nordic aquaculture
\end{tabular}

\subsection{P1 - Adaptations for the future shortage of the existing marine feed resources}

Feeds are the overwhelming material input in the aquaculture production. In the long term the success of the aquaculture industry highly depends on steady availability of sustainably produced feed ingredients.

${ }^{5}$ Sintef, Matis, SLU, DTU, FGFRI, MR-FJLS. 


\subsubsection{Need for alternative ingredients}

At the present fish meal and fish oil are crucial ingredients of aqua-feeds. This is outstandingly true with the Nordic aquaculture which now and in the foreseeable future is strongly based on salmonids, cool water predators with high dietary requirements, and particularly a need for high quality marine oils. The need to find alternatives to the present aquatic feed resources is urgent. While aquaculture production shows steady and rapid growth, global fish catches are stagnating or even slightly decreasing. The world production of both fish meal and fish oil have, according to The International Fishmeal and Fish Oil Organisation IFFO statistics, slipped remarkably from the record levels 20 years ago. Increasing demand of fish meal and particularly fish oil rich in omega- 3 fatty acids for human use, has led to increasing prices and a reduced availability for the aquaculture sector. The production of salmonids is particularly sensitive to this development, since high omega-3 level is one strong argument used to promote salmonid consumption (e.g., Crampton et al. 2010).

Shortage is the main reason for the hunt for substitutes - but not the only reason. Criticism of the net waste of aquatic proteins, using more as input than gaining in output, has increased (e.g. Naylor et al. 2009). The so called FIFO-ratio (Crampton et al. 2019), Fish In vs Fish Out, should preferably be less than one. In addition, increasing environmental concern on the role of the small pelagic species in the marine ecosystems and resources for seabirds has led to restrictions on the fishery. The move away from well-known and safe ingredients to new ones has many challenges (Figure 4). 
Figure 4. Basic premises and external factors affecting to the choice of feed ingredients

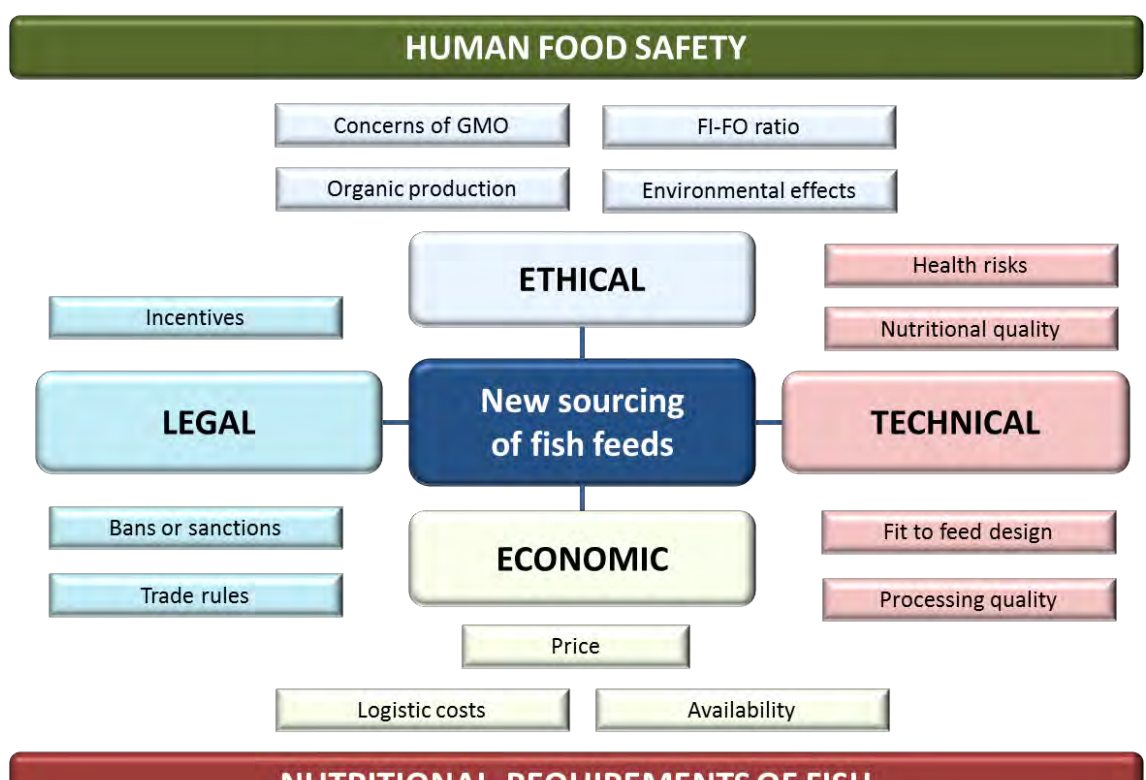

\subsubsection{Potential new sources for aqua-feed ingredients}

A lot of work has already been done to find new industry scale rawmaterials for feeds (Tacon et al. 2011). Partial replacement of fish meal and fish oil with vegetable ingredients has been continuous and rather successful in the farming of salmonids. We want to address focus to three of these sources; (1) Aquatic sources, (2) Agriculture sources and (3) Biotechnological sources.

\section{Aquatic sources}

The utization of trimmings and waste from marine sorurces must increase (Ministry of Fisheries and Coastal Affairs, 2009). A wider use of aquatic resources requires expansion to lower trophic level organisms of oceanic ecosystems. Cool water crustaceans, such as krill, are of high nutritional value (Hansen et al. 2011) and can provide remarkable volumes. Seaweeds can have some potential in the long run. The use of fish industry by-products is already efficient but there is still space for intensification. The potential extra volumes are, however, quite small on a global scale. 


\section{Agricultural sources}

Plant-based ingredients have had a steadily growing share in aqua-feeds (Naylor et al. 2009) and most likely the role will continue to grow remarkably. Soybean, corn, sunflower, beans and lupines are the most potential species groups. Although most animal by-product meals are legally allowed for use in aqua-feeds in the EU (European Commission Regulation No. 1774/2002 and No. 999/2001), the use of by-products in the European aqua-feed industry is clearly lower than outside Europe. Many European countries and feed companies have very precautionary policy and refrain from allowing or using animal by-products in aquafeeds. If satisfactory political or technical solutions to the anticipated risks can be found with consumer acceptance, use of animal by-products can be increased also in Nordic aquafeeds.

\section{Biotechnological sources}

Products of biotechnology are theoretically a rather unlimited resource for aquafeeds. Lab-scale results show that micro-organisms, bacteria, yeasts and micro-algae can produce nutritionally well-balanced proteins and fats. These resources can provide an opportunity to a multipurpose use, such as using sugars for energy and proteins for aquaculture feeds.

\subsubsection{Constraints of new feed ingredients}

In parallel with prerequisites that feedstuffs should be reasonable priced, accessible in adequate quantities and available in forms suitable for feed production technologies, we have identified three important constraints of new feed ingredients to address; (1) Dietary, (2) Environmental and (3) Ethical.

\section{Dietary}

Unbalanced nutrient composition and anti-nutritional, digestibility inhibiting components of novel ingredients set a challenge for the feed design and fish health. Many of the alternatives of aquatic resources contain high amounts of indigestible material and have low content of energy. These weaknesses can depress the growth performance of the farmed fish (Norwegian Scientific Committee for Food Safety 2009).

\section{Environmental}

Environmental issues are predicted to have increasing importance in feed formulation, especially in environmentally sensitive areas. Even legal or administrative limits have been set for main nutrient contents of the feeds. Lower digestibility of new feed ingredients can result in ele- 
vated nutrient releases. Organic fecal wastes from plant-based feeds are a concern as well. Expanding use of recirculation systems in aquaculture set new qualifications for feeds. The properties of fish faeces influenced by the quality of feed can be a risk for water purification in RAS systems (Hjeltnes et al. 2012).

\section{Ethical}

Possible ecological consequences of the effective exploitation of new aquatic resources are not well known. Threats have to be taken seriously. In worst case changes in the ecosystem food chains can be irreversible. Risks connected to genetic manipulations of either feed organisms or fed animals are a common concern for many consumers and scientists. Fears of human health risks with by-products of animal husbandry cannot be brushed aside. Last but not least of the ethical worries is the net effect of aquaculture on the global protein supply. One important sustainability goal is that the industry as a whole should become a net fish producer.

\subsubsection{Adaptations to the shortages}

The FAO has estimated that at least an additional 40 Mtons of seafood will be required by 2030 . This increase rests mainly on aquaculture. The supply of the present main aquafeed sourcing, industrial feed-grade fish, is not growing (Tacon et al. 2011). Huge volumes of new feed ingredients are needed in a mid-long term frame. Some of the production increase might come from cultering herbivorous species, but even they will require good quality proteins to grow (A, Alanära, pers. comm). As a revolution in global scale bio-product supply is not possible, there is a need for diverse solutions and gradual development. Some solutions are at the ready faster than others. Therefore it is important to consider the Nordic adaptations in three different time perspectives; (1) Short term, (2) Mid term and (3) Long term. Optimal use of our Nordic strengths such as access to good quality water sources, highly developed fisheries sector and good national infrastructures should be taken into account in the prioritization of policys and measures.

\section{Short term}

Adaptations required in the short run, or in fact immediately, are more thorough use of the already exploited marine resources and safe increasing of the share of plant-based ingredients in the feeds. This adaptation is based on existing knowledge and on-going development processes (see e.g. EATiP at http://www.eatip.eu). 


\section{Mid-term}

Adaptations on a mid-term (5-15 years) perspective are based on fairly well-known resources and technologies. However, before a large-scale use of new resources, progress in legislation, research and infrastructure is needed. Most potential new sources are by-products of agriculture and underutilized marine resources. A specific limited example of the new marine resources is the use of non-humanfood graded Baltic Sea fish catch for the local aquaculture. The existing detoxification technology allows a risk-free use of catch in aqua-feeds. This kind of nutrient recirculation decreases the external load to the eutrophicated sea (Kiesling, 2009). More incentive based licensing systems are, as we see it, necessary for getting this environmentally beneficiary method in use.

\section{Long term}

For long term adaptations we suggest to focus on time beyond existing prognoses $(>30 \mathrm{y})$. It is a strong consensus that the world population will continue to grow and that agricultural and marine crop will be utilized more thoroughly for direct human nutrition. Finding totally new feed resources is a necessity if aquaculture continues to grow. Microorganisms are among the most promising alternatives for viable use in the northern latitudes and focus should be directed towards supporting this development.

\subsection{P2 - Adaptations for a sustainable use and reuse of carbon, phosphorous and nitrogen}

As in other animal production systems, generation of waste is inherent to the practice of fish-farming. The waste from fish-farms consists of uneaten feed, faeces and respiratory products. Most marine and freshwater culture of fish takes place in net cages suspended in open waters, with no or limited technological possibilities to take care of particulate or dissolved nutrients like carbon, phosphorous and nitrogen. Within the aquatic environment, these nutrients may cause eutrophication problems if released in too high concentrations into recipients with limited capacity. On the other hand, if we can catch and treat these nutrients, they may be of high value in other productions systems. It is a green approach that the organic wastes from fish farms could be used as resources for new products. 


\subsubsection{Recovery of nutrients from aquaculture waste}

Phosphorus is essential for our ability to produce food. Recently, however, a vigorous debate has emerged regarding the longevity of the world's main source of phosphorus - phosphate rock. Like oil, the world's economy is totally dependent on phosphate rock. Our dependence on the latter differs, however, while oil can theoretically be replaced with solar, wind or biomass energy, there is no substitute for phosphorus in crop growth and hence food production. A scarcity of phosphate rock is therefore likely to threaten the world's ability to produce food in the future (Cordell et al. 2011a). Peak phosphorus is estimated to occur by 2035, after which demand would out-strip supply (Cordell et al., 2009a). While the exact timeline might be uncertain, there are no alternative sources of phosphorus on the market that could replace the current global production of 20 million tonnes of P from phosphate rock (Déry and Anderson, 2007; Cordell et al., 2009a; Rosemarin et al., 2009; Smit et al., 2009; Vaccari, 2009). There is no single solution to achieving a phosphorus-secure future: in addition to increasing phosphorus use efficiency, phosphorus will need to be recovered and reused from all current waste streams throughout the food production and consumption system (Cordell et al. 2011b). The world fish farming production in 2004 was about 28 million tonnes per year (FAO 2006). The total worldwide discharge of phosphorus from fish-farms would then approximately be 0.3 million tonnes per year. The phosphorus used in fish feeds has traditionally been of marine origin, so called organic phosphorus. With the increasing inclusion of vegetables in fish feeds, however, the content of phosphorus with inorganic origin has increased rapidly over the last 10 years. Although there are no figures available, the amount of phosphorus with phosphate rock origin may today be about $50 \%$ of the total. A worldwide recovery of phosphorus from human wastes would account for about 3 million tonnes per year, whereas minimizing agriculture farm losses and manure would account for 8 and 15 million tonnes, respectively (Cordell et al., 2009). Thus, aquaculture in general and fish-farming in particular will be one key player of the global phosphorus waste streams in the future.

A modern highly digestible, nutrient dense fish feed yield outputs of about $150 \mathrm{~kg}$ solid waste (15\% dry matters) per tonne fish produced (Cho \& Bureau, 1997). The sludge contains about $20-30 \%$ carbon, and commonly contains $7-32 \%$ of the total nitrogen and $30-84 \%$ of the total phosphorus in the wastewater (Cripps \& Bergheim, 2000). However, little attention has been paid to the development of methods for the further processing of the sludge produced in fish-farms. Unprocessed sludge is diluted and has to be thickened, prior to utilisation, to increase 
the concentration several hundred to several thousand times (Bergheim et al. 1993). Additionally, fresh sludge from fish-farms may contain fish pathogens, and is extremely susceptible to putrefaction. The sludge therefore has to be stabilised, which is a process of hygienisation and prevention of decomposition. There are several potential ways for beneficial disposal of organic waste from aquaculture: application on agriculture land, composting, vermiculture and reed drying beds (Cripps \& Bergheim, 2000). Newly produced sludge from aquaculture is considered a good "slow-release" fertiliser in agriculture with a high concentration of organic matter, nitrogen and phosphorus, but with low potassium content (Bergheim et al., 1993). The carbon part of the fish farming waste has a high potential to be used for biogas or ethanol production.

\section{Future scenarios for the aquaculture sector to consider}

We have identified two future scenarios to consider when looking into the use of sludge from aquaculture. This is highly relevant in a green growth perspectice. The scenarios are considering (1) the recovery of phosphorous, (2) the utilization of sludge. For the latter, efforts have to be made both in terms of general knowledge about charateristics and use, but also development within technology and regulations ( $2 a$ and $b$ ).

1. Phosphorus from the fish-farming industry must to be recovered and re-used. No landbased fish farming will be allowed with rearing systems with no or limited ability for collecting excess feed or faeces (the large P-loss is from cage culture. In 50 years from no we may need to recover all waste streams). The increased costs will to some extent be balanced against the increasing economic value of phosphorus and other advantages of farming in closed systems.

2. The sludge from fish-farms will have a high economic value. Beside phosphorus as fertilizer, it will be used for biogas production or ethanol, and protein production that can be recycled back to fishfarms or other production units.

3. We need to increase our knowledge on sludge characteristics and how to process it for different purposes - technical development.

4. We need new regulations on how to handle and use sludge. 


\subsubsection{Innovative use of nutrients within aquaculture production}

The human impact on aquatic resources may differ dramatically. Some aquatic areas receive too high amounts of nutrients, i.e. eutrophication processes, whereas others are depleted of nutrients due to heavily modified flow regimes, i.e. oligotrophication processes. Eutrophication is the process by which a body of water acquires a high concentration of nutrients, especially phosphates and nitrates. These typically promote excessive growth of algae. Eutrophication is a natural, slow-aging process for a water body, but human activity greatly speeds up the process. Eutrophication problems have been in focus for applied limnology research for nearly half the previous century (Schindler 1974). However, during the past 40 years, the opposite process, oligotrophication, has become an important emerging problem in altered aquatic ecosystems (Ney 1996; Stockner et al. 2000; Hyatt et al. 2004; Anders and Ashley 2007).

During oligotrophication the available amounts of nutrients for primary prodution are significantly reduced, which negatively influences the whole ecosystem. One large antropogenic influence in the Nordic nature is the building of hydro-electrical dams on rivers or on lake outflows. Such constructions increases water retention and rates of degradation and sedimentation of particulate organic matter within the new impoundment; thus reservoirs usually become effective P sinks (Stockner et al. 2000; Anders and Ashley 2007). The oligotrophication process is reinforced by the loss of carbon production from the reservoir littoral community due to large and irregular water-level fluctuations (drawdown), which tend to be most severe in winter when wave erosion and ice-abrasion destroys much of the functional littoral habitat (Nilsson 1964; Stockner et al. 2000). The loss of littoral carbon production and phosphorus by sedimentation and export can severely alter the nutrient dynamics of regulated reservoir ecosystems.

In order to stimulate primary production, and ultimately fish production in hydro-electrical dams, nutrient addition has been used to a large extent in North America (Stockner and Hyatt 1984) and to some extent in Scandinavia (Langeland et al. 1977; Milbrink and Holmgren 1999; Dahl-Hansen 1999). Hyatt et al. (2004) concluded in a large overview that nutrient addition, in general, has been successful in supporting the food web in North American lake experiments. Rydin et al. (2008) performed a whole-lake manipulation experiment in a medium sized Swedish reservoir by adding inorganic phosphorus and nitrogen to the pelagic zone during two consecutive years. Phytoplankton and zooplankton production and biomass increased rapidly, as did the growth and 
condition of fish. The amount of nutrients added in this study corresponds to a fish-farm with a yearly production of 200 tonnes. Milbrink et al. (2008) evaluated the effects of 20 years of moderate and continuous nutrient enrichment on a brown trout population in a regulated lake in Northern Sweden. At the end of the fertilisation period, 4- and 5 year old brown trout was about 3 times larger than before nutrient addition. However, the positive effect diminished quickly after the fertilisation ended, and after 5 years the size of brown trout was back to the situation prior nutrient addition. Fish farming can be considered as an equivalent to nutrient addition as the main waste from the farm is phosphorus, nitrogen and carbon. In addition, nutrients from fish-farming may even be a better way to achieve positive ecosystem effects.

The phosphorus is organic, it enters the system in small doses over the productive period, and a substantial part of the nutrients enter the food chain directly by consumption of wild fish and zooplankton. Lakes and rivers used for hydroelectric power production typically have large water flows and long turnover times, conditions that are ideal for fish farming. Impoundment dams are also suitable because they hold no or few protectable wild fish populations have good physical conditions in terms of water depth and temperature, potentially few other users of the resource and easier access to water areas because of the owner structure.

The Baltic Sea is a heavily disturbed ecosystem with numerous problems out of which the eutrophication is one of the most important. This is the major reason for why the Baltic Sea today is less suitable for fishfarming activities. One factor reinforcing the eutrophication process is the unbalanced outtake of predatory fish (e.g. cod) by the commercial fisheries. Casini et al. (2008) showed that the dramatic reduction of the cod population due to a high fishing pressure in the Baltic Sea directly affected its main prey, the planktivorous sprat, which increased dramatically in population size. This had an indirect effect on the summer biomass of zooplankton and phytoplankton, where sprat consumed large amounts of zooplankton that in turn lost their regulatory effect on phytoplankton. They suggest that in order to reduce the harmful algal blooms of the Baltic, effort should be addressed not only to control anthropogenic nutrient inputs but also to preserve structure and functioning of the ecosystem.

The removal of planktivorous fish in eutrophicated lakes is a method that has successfully been used for many years, a so called biomanipulation. As a consequence of the unbalanced trophic levels in the Baltic Sea, biomanipulation may be suggested as one method to reduce the negative effects of substantial algal blooms, where the primary goal is to reduce 
planktivorous fish populations. Once fished, these populations might be seen as a resource that can be used in other production systems like fishfarming. The Baltic Sea catches of planktivorous fish (sprat and herring) was in 2011 about 120,000 tonne. This corresponds to about 80,000 tonne of fish feed or 60,000 tonne farmed fish. In addition, the amounts of nutrients removed from the Baltic Sea would be 516 tonne phosphorus and 2,880 tonne nitrogen per year, i.e. a positive ecosystem effect.

Besides phosphorus and nitrogen removal from overloaded aquatic systems by fishing out planktivorous fish, we can "catch" nutrients by farming filter feeders or aquatic plants (algae and kelp). One such example is using blue mussels as an ecosystem service in eutrophicated sea areas. Calculations have shown that blue mussels remove $0.65 \mathrm{~kg}$ phosphorus and $10 \mathrm{~kg}$ nitrogen per tonne produced. Thus, by establishing mussel farms in nutritional rich areas, the removal of nutrients can be substantial. Blue mussels have a high quality protein content that would be beneficial to use in, for example, fish feed. Likewise, new research on kelp indicate that kelp can take up 10-30\% of the dissolved nitrogen in the sea (Handå et al. 2009), so a placement of kelp growout facilities downstream of open sea cage aquaculture whould be a way to obtain a green growth objective. Through aquaculture we have access to a lot of raw material that can be used to produce useful carbon based products like biogas, ethanol or protein. Most of this raw material comes from agriculture and forestry either directly or as by-products.

One interesting by-product is sugar from paper mill plants. Within the process, about $50 \%$ of the fibres become paper and $50 \%$ by-products in the form of short sugar in rinse water. Some of the sugar is already used for the production of biogas and ethanol, but a major part is considered as waste products is not utilised. The majority of paper mills in Sweden is situated near the coast and often uses the sea directly as a recipient of waste products. By using micro-organisms like zygomycetes (e.g. mould), yeast or bacteria, a large part of the carbon or sugar, and some phosphorus and nitrogen, can be transformed into useful proteins. The paper mills in Sweden produce approximately 1.5 million tonne sugar per year as byproducts in the process. The efficiency by which zygomyzetes transform sugar into protein is about $50 \%$. There are still several uncertainties about the quality and usefulness of zygomyzete protein for fish feed, although some preliminary tests show promising results. Nevertheless, the use of this protein source may correspond to roughly 1.2 million tonnes of fish feed (see relevance for P1 described in earlier section). In addition, one tonne of zygomyzete production will remove about $20 \mathrm{~kg}$ nitrogen from 
the effluent water from paper mills. This will significantly reduce the environmental load on the Baltic Sea.

Whether or not discharge of nutrients from fish farms may lead to eutrophication in Norway has caused a debate in media and among research institutions. An observed reduction in sugar kelp and heavy loads of epiphytes has been suggested as a result of fish farming. As a result of these discussions a group of experts was called upon by the Norwegian Ministry of Fisheries and Coastal Affairs, The Norwegian Ministry of Environment and The Norwegian Climate and Pollution Agency (KLIF). The expert group evaluated the effects of nutrient releases from fish farming but found no evidence for a eutrophicated status. The OSPAR criteria for an eutrophication effect, a $50 \%$ increase in phytoplankton biomass, were not found in any of the investigated ares. A comparison of benthic algae in Hardangerfjorden from the 1950s and today show an increase in diversity and more southern species are found, which might indicate a climatic effect. The distribution of habitat-building species, like kelp and fucoids, were unchanged in the Hardangerfjord compared to the 1950s. There are no signs of a reduced lower growth limit of sugar kelp and grazing seaurchins often sets this limit. The concentrations of nutrients in both fjords are within the status Good or Very good according to KLIFs criteria for water quality. Likewise, the Institute of Marine Research i Norway have presented a risk analysis for Norwegian fish farming and concluded that the risk for regional or eutrophication of norwegian coastal waters used for fish farming is low (Taranger et al. 2011). The sea areas suitable for aquaculture in Norway are therefore of another status, regarding to eutrophication and nutrients than the Baltic Sea.

\section{Future scenarios for the aquaculture sector to consider}

We have identified three future scenarios for the aquaculture sector to concider when looking into the innovative use of nutrients. This is highly relevant within the green growth perspective. These consider (1) Utilizing nutritional rich water bodies as a resource, (2) The utilization of power dams, and (3) the utilization of non-digestible feed source to become digestible for humans by way of fish. 
1. Fish farming will be an integrated part in environmental management plans. We will see nutritional rich water bodies as resources rather than problems, used to produce valuable proteins and fats. If we use these to produce fish in farms we will re-circulate nutrients either within the system or by moving nutrients to other systems (see next paragraph). The effect in both cases will be a net outtake of nutrients from overloaded water. Such management strategies will help to reduce eutrophication problems.

2. We will be able to improve ecosystem functions in dams regulated by the power industry by moving nutrients from "rich" areas by way of fish farming into "nutrient poor" areas. The "Robin Hood principle" take from the rich and give to the poor.

3. There will be competition for carbon rich waste material. The main actors we can identify today is biogas, ethanol and "bio-protein" where the latter can be used for fish feed. Proteins produced by micro-organisms contain high amounts of amino acids that landliving farmed animals and humans nutritionally have problems to handle. Fish on the other hand seem to be able to handle these amino acids and convert them to proteins for human consumption. This means that we convert a non-digestible feed source to be digestible for humans by way of fish.

\subsection{P3 - Adaptations for creating added value based upon utilization of by-products}

\subsubsection{The by-product situation today}

The Nordic aquaculture industry "produced" 280,000 tons of byproducts in 2010, and most of the by-products are utilized today (Table 7 and Table 8). 
Table 7. By-products from aquaculture in the Nordic

\begin{tabular}{|c|c|c|c|c|}
\hline Country & Production (Mtons) & Main product & By-product & Amounts (MTons) \\
\hline \multirow[t]{3}{*}{ Finland } & 11,000 rainbow trout & Head-on gutted & Viscera & 1,000 \\
\hline & 1,000 others & & Dead fish/discharge & 100 \\
\hline & & & & Total: 1,100 \\
\hline \multirow[t]{5}{*}{ Norway } & $1,000,000$ salmon & Head-on gutted & Viscera/cuts & 163,000 \\
\hline & and rainbow trout & Processed fish & Discharge & 27,000 \\
\hline & & (filet, portions) & Heads & 20,000 \\
\hline & & & Dead fish & 50,000 \\
\hline & & & & Total: 260,000 \\
\hline \multirow[t]{3}{*}{ The Faroe Iceland } & 41,000 salmon & Head-on gutted & Viscera & 4,800 \\
\hline & & & Dead fish/discharge & 3,300 \\
\hline & & & & Total: 8,100 \\
\hline \multirow[t]{3}{*}{ Denmark } & 36,500 rainbow trout & Head-on gutted & Viscera & 4,300 \\
\hline & 1,500 eel & & Dead fish/discharge & 1,900 \\
\hline & 1,300 others & & & Total: 6,900 \\
\hline \multirow[t]{3}{*}{ Sweden } & 7,800 rainbow trout & Head-on gutted & Viscera & 1,000 \\
\hline & 1,300 arctic charr & & Dead fish/discharge & 100 \\
\hline & 1,000 others & & & Total: 1,100 \\
\hline \multirow[t]{3}{*}{ Iceland } & 3,000 arctic charr & Head-on gutted & Viscera & 600 \\
\hline & 1,100 salmon & & Dead fish/discharge & 350 \\
\hline & 1,200 others & & & Total: 950 \\
\hline Sum & $1,108,000$ & & & 280,000 \\
\hline
\end{tabular}

Estimated from RUBIN, The Danish AgriFish Agency, The Finnish Game and Fisheries Research Institute's, The Icelandic Aquaculture Association, Faroese Bureau of Statistics, production figures from Sweden.

Discharge of by-products into the environment is not an issue, and feed, consumer-products and oil for technical use or energy production are main areas for utilisation.

Table 8. Utilization of by-products in the Nordic countries

\begin{tabular}{|c|c|c|c|}
\hline Country & $\begin{array}{r}\text { Feed/technical } \\
\text { use (tons) }\end{array}$ & $\begin{array}{r}\text { Consumption } \\
\text { (tons) }\end{array}$ & Comments \\
\hline Finland & 1,100 & & Feed for fur farming, Roe \\
\hline Norway & 210,000 & 50,000 & $\begin{array}{l}\text { Consumption includes production of } 20,000 \text { tons } \\
\text { of fresh oil. Source: www.rubin.no }\end{array}$ \\
\hline The Faroe Iceland & 8,100 & & $\begin{array}{l}\text { Ensilage to protein concentrate/oil, technical oil } \\
\text { to fur industry, fresh oil }\end{array}$ \\
\hline Denmark & 6,900 & & Ensilage to protein concentrate/oil, Roe \\
\hline Sweden & 1,100 & & Ensilage to protein concentrate/oil \\
\hline Iceland & 950 & & Ensilage to protein concentrate/oil? \\
\hline Total & 228,000 Mtons & 50,000 Mtons & \\
\hline
\end{tabular}

Estimates based on information mainly from the expert group. 
In the Nordic countries, and especially in Iceland, Norway and Denmark, a marine ingredient industry has developed in the last 10 to 15 years. Some stakeholders in this industry are based on imported raw material such as fish oil from South America, but several companies have based their production on by-products from the aquaculture industry and/or from the traditional fisheries. In Norway, the marine ingredient industry represents an annual turnover in 4.8 billion NOK (Richardsen 2010), representing process industry in the feed-, petfood-, food supplement-, functional food- and pharmaceutical market. The most successful products are the omega-3 capsules. A recent report by Winther et al. (2011) concludes that concludes that an increased utilisation of by-products has good potential for value adding.

There is a market for by-products utilized directly as food. Important food-products are head, belly flap, liver (cod), roe, milt and stomach. It is an interesting discussion whether this is a by-product or the main product. As an example from Denmark, the roe production from rainbow trout is increasingly important. According to our information the Asian and Eastern Europe/Russia are the current growing markets for consumer by-products.

By-products from the traditional fisheries are important inputs into fish feed as fishmeal/oil, protein concentrate/oil, protein hydro lysate/oil or special ingredients. There is an increasing interest from the fish feed companies, due to shortage of marine based feed ingredients (oil and protein) for better utilization of these resources as a protein and oil source.

In Norway the fisheries "produced" about 650,000 tons of byproducts in $2006^{6}$. About $70 \%$ was utilized by industrial stakeholders, while 200,000 tons by-products were dumped by the fishing fleet.

In Iceland the motivation to increase the value of the catch has been enforced and ever increasing since the formation of the AVS Research fund in fisheries, resulting in increased variation of seafood products for consumer markets generated from by-products. Dumping has therefore been reduced and in most cases approximately $90 \%$ of the demersial catch is processed further and what once was waste is being processed for either nutritional, cosmetic or design purposes. It is estimated that in case of cod that is processed on shore, up to $97 \%$ is being utilized. Demersial fishing was traditionally responsible for generating the most of by-products. From the 2010 summarized catches of cod, haddock and

${ }^{6}$ Source: www.rubin.no 
saithe of 297,358 tons, approximately 47,782 tons of by products were generated. 33,000 tons were reduced to meal and oil (trimmings and liver). 7,011 tons were frozen on sea (heads and trimmings). 2,980 tons were salted (roes). 2,782 tons were canned (liver) 1,402 tons were frozen on land (roes and trimmings). 169 tons were dried. 240 tons were consumed domestically and 83 tons were exported by flight or containers (pers.comm. Arnljotur B. Bergsson).

In Faroese the demersal fisheries waters are regulated by a days-offishing system, i.e. an effort system as opposed to a quota system. This effectively eliminates any incentive for discarding whole fish in the demersal fisheries, which is a major issue in neighbouring countries. Increased attention has been given to utilising by-products from the demersal fisheries. Approximately $90 \%$ of demersal catches are currently further processed. Nearly all demersal heads and spines are dried and exported for human consumption, primarily in European and African markets. Roe and liver are salted or canned or used to produce oil. Trimmings are reduced to meal and oil. Guts and intestine are largely not utilized (and only a small share of roe and liver) and mostly dumped at sea - but both industry and authorities are working on increasing the utilisation of these by-products (pers.comm. Pól Egholm).

\section{Sustainable use of all resources in the value chain}

There is a need change how we think about aquaculture. Today the production process is often seen as linear and few thoughts have been put into how each step in can be optimized with regards to increased resource use. Waste, produced at each step is a resource that can be better utilized. As a result, production will increase founding a basis for new jobs based on by-products. Extractions of valueable by-products from waste products decrease the pressure on the marine-resources. The linear production processes are changed to circular, where waste from one production becomes raw-materials for other productions. To further increase the sustainability of aquaculture it is important to maximize the use of local resources in order to minimize the carbon footprint of the production.

\subsubsection{Perspectives}

We predict that by-products from the aquaculture industry (and fisheries) will add higher value to the main product than today - and in some aspects today's by-product will turn into the main product. As a consequence in a 30 years perspective, we will not divide the fish into "main" or "by" products. A better utilization is in line with the new marine policy in EU, which is clear in its requirements for the future: (a) Discharge 
of fish will not be allowed (b) The whole fish must be taken care of and utilized for feed, food or other products.

Increased focus on utilization of by-products will give a significant contribution to a more "green" industry in the Nordic countries. By so we recommend that this topic should be considered when shaping the Nordic policies. We signalize that the four most important aspects to consider in this matters are:

\section{Adaptations for developing local marine ingredient industry close to} the by-product resources.

The processing industry is struggling to achieve profitability and there are many important jobs in rural areas connected to processing factories. In the future, the value of the by-products will probably create increased profitability of the industry. We recommend that parts of the processing industry (especially the part dependent on fresh raw material) should be located close to production units, i.e. in rural areas in Nordic countries. The foundation for developing products based on by-products must be given focus by the policy instruments as research, innovation, and finance. Local production of fillet and other processed products will contribute to reduction in climate gasses due to less need for transport. A tailormade production of advanced fish products will also in the future happen close to the costumer, but production of semi-finished products, like fillets, will happen close to the fish farms. About $20 \%$ of the fish produced in Norway (and the percentage are about the same in the Nordic countries) are filleted today, but in the future we expect this percent to increase which will lead to more resources locally for an activity based upon by-products. In Figure 5 we are visualizing what an increase up to $50 \%$ filleting in 2030, could give in terms of quantities of by-products.

\section{By-products from fish for human consumption.}

There is an increased demand for cheap seafood, snacks and flavour oriented products. For example belly-flaps are used for dry snacks in bars in Eastern Europe, dryed and used for topping on sushi in Japan. Fish heads are used for soups etc. Policies stimulating the development of products, technology, logistics and markets for byproducts, should be addressed on the Nordic level through instruments like Nordforsk and Nordic Innovation. 
3. The ingredient industry as a market.

Fish by-products are important raw-material for an ingredient industry producing healthy products for animals and people: petfood, health foods, functional foods can be based upon by-products from aquaculture and fisheries. At the moment, stakeholders such as EPAX, Pronova Biocare, Hordafôr are taking a leading role in producing ingredients based on marine resources. Still the industry needs to be strengthened and backed up by the governments and the Nordic policy system since most of the companies are small and with limited resources (capital, competence etc).

4. By-products as fish feed.

This utilization needs to be addressed, especially since marine oils and proteins are future limiting factors for increased aquaculture production. The fish feed companies are already investigating all possible marine oil and protein sources as discussed earlier. Byproducts from fisheries and aquaculture production are very interesting sources and regulations are partly changing. As an example: Salmon oil is by now permitted for use in salmon feed (and feed for other species). We recommend that efforts are taken to develop a Nordic knowledge platform for safe use of by-products from aquaculture as feed ingredients for aquaculture.

\subsubsection{The by-product situation in the Nordic countries in the near future}

We have calculated the by-product raw-material situation as a consequence of a predicted increased aquaculture production with higher proportion processing in the Nordic countries. In a scenario where the Nordic aquaculture industry grows with an overall rate of $5 \%$ per year and filleting is increased from current $20 \%$ to $50 \%$, the production of by-products will reach 1,300,000 tons of by-products in 2030. Therefore, if we succeed in developing the aquaculture sector, we must be prepared to handle vast quantities of by-products and that should be done in the most sustainable ways. 
Figur 5. The amount of by-products resources potentially available during a 5\% per year growth scenario of Nordic aquaculture and a local filleting proportion of 20\% from 2010 to 2020 and a filleting proportion of 50\% from 2030

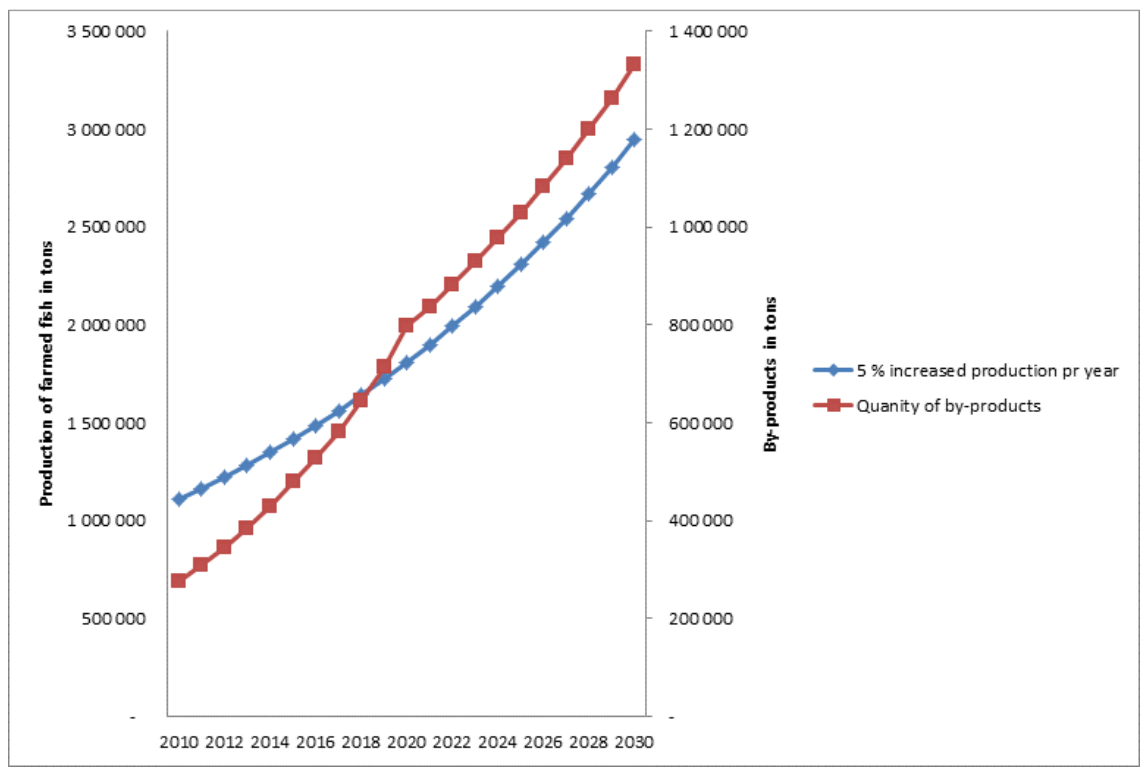

Summing up we underline that the most important challenge in a Nordic perspective on green growth is how to increase and add value to the byproducts in order to strengthen the sustainability of the industry as a whole. This will contribute substantially to a green growth development.

\subsection{P4 - Technology development to maximise aquaculture potential by removing major constraints for viable growth}

The potential for food production through aquaculture in the Nordic countries are not fully utilized. However there are obstacles to overcome. Some of the obstacles to maximising the Nordic aquaculture potential are listed in the introduction (Table 2). Policies and measures stimulating a technological development aiming to remove some of these obstacles are recommended. On a broad scale there is a need to improve technology in both aquaculture operations and production systems. Our belief is that further growth of Nordic aquaculture, amongst other measures, can be facilitated by making improvements to and introducing new technology. Recent analysis of the total factor productivity change in e.g. Norwegian Salmon Aquaculture show a change of $1-2 \%$ a year, where the contribu- 
tion from technical efficiency change is between $0.2-1.2 \%$ and technological change is between $0.6-0.8 \%$ (Nielsen 2012).

\subsubsection{Operations}

By operations we mean the knowledge (and technology) of how things are done in aquaculture. The history of farming Atlantic salmon and rainbow trout provides many examples of such means. Today, we have a reasonably good overview of the risks, causes and potential consequences of incidences in salmon farming, much due to the focus the industry has laid upon it and the governance that has now been established as measures. It is likely that the same types of challenges are experienced in farming of other species, though they are currently not so much in the public eye. The volume of a typical salmon cage is now 128 times bigger than 30 years ago (Andaur et al. 2012). The number of sealice per fish has been reduced, but at the same time the total number of fish has increased, so the extent of the salmon lice problem is possibly the same as it was several years ago. The same holds for escapees, especially given that the number of fish escaping is still large when compared to the wild salmon population, even if the proportion of escapes is very low ( $>1 \mathrm{ppt}$ ) relative to the total number of farmed fish. About $5 \%$ escapes occur from closed landbased fish farms, 16\% during transport, $14 \%$ at the harvesting plant and $65 \%$ in ongrowing farms at sea (Anduar et al. 2012). 80\% of these incidences are caused by human errors. In 2010, 24 escape incidences were reported from salmon production in Norway and the causes for these were typical; handling fish (21\%), the systems for distending the nets (29\%), tearing (13\%), propellas (8\%), and other holes in the net (29\%). Net holes often occur during handling of heavy equipment as part of the normal production procedure, or by wear and tear when nets come into contact with chains and ropes. Development of stronger net materials has not received much attention until recently. However, given the risk associated with net holes resulting from handling and operations it is important that this is prioritised for future research and development. Since it's not the breakdown of total farmingsystems that is the problem now, more attebtion to holes caused by production equipment and operations must be addressed.

Technologies for sterilising farmed salmon are currently developing and provide promising new measures that can have a major benefit towards reducing the constraint for growth associated with escapees. The environmental consequences and the biological performance of hybrid- 
ized fish are not well known. We signalize that this area might be of high importance in future research.

The battle against some of the well known fish pathogens for salmonids is largely won thanks to the development of efficient vaccines and individual vaccination of each fish. Selective breeding programs have improved the robustness of fish towards pathogens and handling. The latter illustrates the importance of domestication. Possible, new diseases may develop, but on the current knowledge basis it is likely that we are able to cope with such developments.

\subsubsection{Production systems}

\section{Open water}

Salmon production has, since the 1970s, gradually moved from small, shallow, square, fixed frame systems into large scale circular floating flexible systems of increasing diameter and depth (Andaur et al. 2012). Different systems available have been dicussed by Aarhus et al. (2011). The relation between cage diameter and volume and thus production capacity favors the use of large floating structures, also in terms of investment costs $\mathrm{pr} \mathrm{m}^{3}$ farming volume (Rosten et al. 2011). This trend is expected to continue but it is likely that there will be a wider variety of technologies for farming in sea in the future (Andaur et al. 2012). Several systems and production strategies are under development or being tested in order to minimize interaction with outside environment. A description of such type of closed technologies can be found in Rosten et al. (2011) and Andaur (2012). Systems with improved abilty to collect sludge are relevant for the issue of phosphorous discussed under P2 earlier in the report. Development of technologies for more exposed sites (even offshore) is described later (p. 63). This forms a background for future research and development of systems for open water.

\section{Landbased systems}

The basis for the Norwegian, Icelandic and Swedish success with landbased production of smolts of Atlantic salmon and rainbow trout and production of portion sized Arctic charr is the gravity fed flow-through system. It is simple and secure as long as the watersource is sufficient enough to provide enough water. Clean water is efficient in removing metabolites from a fish tank as long as the biomass does not exceed the limit. Correct placing of a pipe with freshwater discharge, has been shown to increase circulation and local conditions in a fjord with otherwise stagnant oxygen depleted bottom water (pers. comm. Idar Klungervik). Major production 
improvements allowing a higher biomass to water volume ratio in landbased systems have been made possible by the use of liquid oxygen and carbon dioxide degassers. The weaknesses of this technology are consumption of energy for heating, oxygenation and degassing water, and limited possibillites for removing sludge from the discharge. Access to large amounts of freshwater with a natural water pressure (head), are one of the competive advantages of Norway. If water pressure can not be obtained naturally, it is common to use pumps to provide the flow-through of water. Natural varying water quality conditions containing metals and or low $\mathrm{pH}$, have been shown to cause problems in Norway and Chile (Kristensen et al. 2009), and can be one argument to use recirculation production systems in certain areas (Hjeltnes et al. 2012).

\section{RAS}

Freshwater recirculated production systems (RAS), which are emerging particularly in Denmark and Norway, are often located at the sites of the old pond farms they are replacing or at ongowing flow-trough hatcheries. The independence of a large water source, need to conserve the recreational interests of the river valleys combined with infrastructure, access to housing areas etc. makes a move into more general industrial areas likely. This will to some extent counteract a wish to support rural areas by creating job opportunities in these areas. This is a dilemma. At present RAS are in a fast phase of replacing traditional pond productions in Denmark, but there is still a need of knowledge on their function and economy. In Norway and the Faeroe Islands, RAS are being used as the technology in most new build hatcheries for the production of smolts. Facilities with production capacity of more than 14 million smolts are under construction. Technology shift in Norway seems to be driven by a need for expansion of the smolt production at sites with already fully utilized freshwater supply and a motivation to consume less energy. But most important, an increased ability to produce smolts year around since this is beneficial for maximizing the standing biomass regime, which is part of the regulation system used in Norway.

Reduced discharge of organic material, nitrogen and phosphorous has so far not been important for the implementation of RAS in Norway and there are serious weaknesses in the ability to treat sludge collected from hatcheries in terms of regulations, logistics, cost, treatment plants and climate budget. The high price per kg smolt $\sim 100 \mathrm{NOK} / \mathrm{kg}$ makes this technology possible in the early statges of salmon production (pers. comm. Trond Rosten). Problems with geosmin taste of the flesh are another issue to solve when RAS is used for producing harvestable fish sizes. RAS systems for sea water recirculation are also available but still require research and testing before it is sufficiently reliable. The use of RAS has 
many advantages i.e. independence from river/lake water, control of temperature and chemical/physical conditions, reduced risk of infections/infestations and lower discharge of nutrients into the environment. They are able to produce fish in high densities with low mortalities (Hjeltnes et al. 2012). The systems are, however, costly to establish and run when compared to traditional open systems and their use will probably primarily be where environmental restrictions excludes open systems and where a higher production cost can be justified in relation to the advantages of the technology (pers. comm. Helge Paulsen).

\subsection{P5 - Boosting the competiveness in Nordic areas attractive for aquaculture}

Obtaining a birdview perspective on the Nordic aquaculture (Figure 3 and Table 9), it is clear to us that there are several areas attractive for increased aquaculture production (AAA). However each of these AAA has different challenges that need to be addressed in order to develop their potential. Some of these areas share some of the same obstacles, but generally the workgroup have reached the conclusion that they are quite diverse and need different actions. The challenge on a Nordic policy level is to obtain a mutual understanding of each AAA and how we can increase its competitiveness. Green growth perspectives must address how to stimulate sustainable development in those areas. The current rather distressed competitive position of aquaculture in the Nordic countries has been introduced earlier (Table 4). It is likely that policies for future utilization of the potential for aquaculture must be directed towards increasing the Nordic competitiveness while developing the green growth perspectives simultaneously. 
Table 9. Nordic areas attractive for increased aquaculture production. A suggestion for key species, technology and green growth challenge and perceived obstacles for growth

\begin{tabular}{|c|c|c|c|c|}
\hline AAA & Key species & $\begin{array}{l}\text { Obstacles for } \\
\text { growth }\end{array}$ & Technology & Green growth challenge \\
\hline $\begin{array}{l}\text { Coast } \\
\text { around } \\
\text { Faroe } \\
\text { Islands and } \\
\text { Norway }\end{array}$ & $\begin{array}{l}\text { Atlantic salmon } \\
\text { and rainbow } \\
\text { trout } \\
\text { Cod }\end{array}$ & $\begin{array}{l}\text { Salmon lice } \\
\text { Escapees }\end{array}$ & $\begin{array}{l}\text { A combination of } \\
\text { open net based and } \\
\text { closed farming } \\
\text { technology } \\
\text { More offshore } \\
\text { based }\end{array}$ & $\begin{array}{l}\text { Developing technology reducing the risk } \\
\text { of escapes } \\
\text { Measures towards sealice } \\
\text { sterile salmon }\end{array}$ \\
\hline $\begin{array}{l}\text { Denmark - } \\
\text { onshore }\end{array}$ & $\begin{array}{l}\text { Rainbow Trout } \\
\text { Pike pearch } \\
\text { Eel } \\
\text { Blue mussels }\end{array}$ & $\begin{array}{l}\text { Feed quotas } \\
\text { High nutrient } \\
\text { loads in the Baltic } \\
\text { sea / Skagerak }\end{array}$ & $\begin{array}{l}\text { "Model fishfarms" } \\
\text { (RAS) for land } \\
\text { based production }\end{array}$ & $\begin{array}{l}\text { Have to see blue and green sector as one } \\
\text { Establish solution with tradeable nitrogen } \\
\text { discharge quotas (Nielsen, 2012) }\end{array}$ \\
\hline $\begin{array}{l}\text { Sweden - } \\
\text { oligitrophic } \\
\text { freshwater } \\
\text { sources } \\
\text { and coast. }\end{array}$ & $\begin{array}{l}\text { Arctic charr } \\
\text { Rainbow trout, } \\
\text { blue mussels }\end{array}$ & $\begin{array}{l}\text { Knowledge in } \\
\text { central and local } \\
\text { government } \\
\text { administration. } \\
\text { High nutrient load } \\
\text { in the Baltic sea. }\end{array}$ & $\begin{array}{l}\text { A combination of } \\
\text { net based cage } \\
\text { culture and land } \\
\text { based technology }\end{array}$ & $\begin{array}{l}\text { Use the "Robin Hood Principle" with feed } \\
\text { fish from the Baltic sea } \\
\text { New fish feed technology from paper mill } \\
\text { waste. } \\
\text { Utilize power dams/rivers for fish produc- } \\
\text { tion. Blue mussels as nutrient cleaning } \\
\text { organisms (sea) }\end{array}$ \\
\hline $\begin{array}{l}\text { Finland- } \\
\text { oligotrophic } \\
\text { freshwater } \\
\text { sources } \\
\text { Archipelagic } \\
\text { peninsula of } \\
\text { Baltic sea }\end{array}$ & $\begin{array}{l}\text { Rainbow Trout } \\
\text { Pike perch } \\
\text { Blue mussels }\end{array}$ & $\begin{array}{l}\text { The regulatory } \\
\text { regime prevents } \\
\text { development and } \\
\text { growth. High } \\
\text { nutrient load in } \\
\text { the Baltic sea }\end{array}$ & $\begin{array}{l}\text { A combination of } \\
\text { net based cage } \\
\text { culture and land } \\
\text { based technology }\end{array}$ & $\begin{array}{l}\text { Use the "Robin Hood Principle" with feed } \\
\text { fish from the Baltic sea } \\
\text { New fish feed technology from paper mill } \\
\text { waste } \\
\text { Blue mussels as nutrient cleaning organ- } \\
\text { isms } \\
\text { Have to see blue and green sector as one } \\
\text { Establish solution with tradeablenitrogen } \\
\text { quotas } \\
\text { ICZM }\end{array}$ \\
\hline $\begin{array}{l}\text { Iceland - } \\
\text { onshore } \\
\text { and fjords }\end{array}$ & $\begin{array}{l}\text { Arctic charr } \\
\text { Atlantic Salmon } \\
\text { Halibut } \\
\text { Tilapia }\end{array}$ & $\begin{array}{l}\text { Escapees } \\
\text { Limited sea } \\
\text { farming areas due } \\
\text { to protection }\end{array}$ & $\begin{array}{l}\text { A combination of } \\
\text { open sea cage } \\
\text { farming and land } \\
\text { based farming }\end{array}$ & $\begin{array}{l}\text { Utilize geothermal sources for heating of } \\
\text { water in aquaculture to minimize use of } \\
\text { energy }\end{array}$ \\
\hline
\end{tabular}

Aquaculture is well positioned to increase production of animal protein and by doing so contribute to anticipated increasing global food predicted by FAO. In order to take on these challenges it is important to deal with the growth constraints that have been identified as barriers for expansion of aquaculture in the Nordic countries (Table 9, Table 2, and Table 5abcd). Aquaculture production requires much less space than the comparable agriculture production of animal protein (when taking the underlying feed plant production into account) and compared to other animal food production, aquaculture is relatively environmental friendly food production technology (Torrissen et al. 2011). Regardless of that strict limitations apply to where sea-based aquaculture is currently permitted.

The workgroup has identifiyed that regulations around discharge of nutrients are important to adress if aquaculture in the Nordic countries is to develop. The topic have thouroghly been dicussed by Nielsen 
(2012). Discharge of nitrogen and phosphorus from aquaculture may in some cases cause eutrophication, oxygen depletion and other negative effects on the environment. To avoid this, restrictions apply on the discharge either by limitations on e.g. the fish production (Norway) or e.g. on the feed consumption (Denmark). Nitrogen and phosphorus are, however, also discharged into the environments from sewage plants and agricultural runoff. In Denmark and most of the EU, the agricultural sector is the main source of nitrogen pollution. In Denmark more than $70 \%$ of total Nitrogen emisions comes from the agricultural sector (Nielsen 2012) All sectors are actively working to reduce such discharge, but the costs of achieving a certain reduction are probably very different. It is likely that the production value giving a certain discharge is much higher in aquaculture than in agriculture, where much of the production value is associated with the value of various subsidies. It is therefore recommended that a system of transferable nutrient discharge quota is established. Using such a system, market mechanisms will determine to which extent discharge from high value aquaculture can replace discharge from low value agriculture. It will be an efficient measure to combine "green growth" with obtaining acceptable environmental standards, as described e.g. in the "EU Water Framework Directive". Valuation of nutrient discharge and removal could promote production of mussels and kelp which removes nutrients from the environment.

Land-based aquaculture is limited by fresh water/brackish water supply and is considerably more expensive than aquaculture in sea cages (Rosten et al. 2011) but is suited for the production of high priced species and smolts. Inland aquaculture in Sweden, Finland and Norway is limited by access to suitable freshwater sites. Nevertheless the work groupthink that there are possibilities for expansion of aquaculture as long as the future growth is sustainable.

The working group has concluded that there are five main policy areas to be adressed in order to utilize AAA in the Nordic countries. These are (1) technology for preventing escapees and allowing development of offshore aquaculture and (2) new technology for land based aquaculture (RAS), (3) integrated coastal zone management (spatial planning) (4) special means for the Baltic Sea area and (5) new ecosystem based management.

\section{(1) Technology for preventing escapees and allowing development of offshore aquaculture}

To enable production expansion of Atlantic salmon, we anticipate technology development to establish escape proof and safe offshore aquaculture facilities. These must be able to cope with high seas and extreme weather in exposed areas. Sea based aquaculture in the western part of 
the Nordic area, e.g. Iceland, The Faroe Islands and Norway will remain limited until technology is developed to answer the escapement and spatial conflict issues. This may also be the case in other countries e.g. cage farming of rainbow trout in Baltic sea, and Arctic charr in freshwater systems. New knowledge of materials and construction are required in order to conduct aquaculture in more exposed ocean sites. From a 30 year perspective we foresee the need for construction of new, integrated infrastructures for transport, production and harvesting in large scale units adapted to more exposed conditions. Dualistically one has to develop an environment that is suitable for fish production and an installation that is safe and easy to operate for humans. Licensing sea areas for aquaculture in a way not unlike that which exists for the oil and gas industry in the North and Norwegian seas is one possible direction for policy to develop. A governmental initiative for impact assessments of the risk of having large scale off shore areas for aquaculture (aquaculture fields) should be launched.

\section{(2) New technology for land based aquaculture (RAS)}

We foresee a potential to develop landbased aquaculture of high cost products such as female rainbow trout with roe, pike perch, smolts of salmonids, eel and exotic species like sturgeon and tilapia. The Nordic aquaculture sphere could benefit by utilizing the RAS technology developed and adapted in the Denmark - Norway - Faroe Islands - Iceland axis. RAS technologies make it possible to recollect a large proportion of phosphorus, carbon and nitrogen. As described earlier these resources could be regarded as valuable by-products. RAS could contribute to a development where that aquaculture can be established in areas previously limited by strict discharge regulations (Table 9). The Danish ideas and experiences with "modeldambrug" would be of vital interesst to implement in suitable areas and with certain species. We foresee also that RAS technology is going to be important for the production of the first stages of salmonids (up to $1 \mathrm{~kg}$ ). This is in line with future scenarios given by Andaur et al., 2012.

Hydropower basins have earlier in this report been described as potential sites for fish farms. On this basis new AAA for species like Arctic charr and rainbow trout can be developed inland even with open netbased cage systems. The technology development should focus on the same challenges as cage systems for open marine aquaculture, but in addition focus on protection for and operation in ice. 


\section{(3) Integrated coastal zone management (spatial planning)}

The positive effect of spatial planning in developing aquaculture is demonstrated in Norway. We see a development where aquaculture production has been increasing for years while the number of farms has decreased, which has led to bigger production units. Conflicts with other use such as fishing and spawning grounds, shipping lanes and marine protected areas can be difficult to avoid so spatial planning and site structures are important tools for long-term environmentally sustainable development of the aquaculture industry (Bryde 2012). Spatial planning should take into account the carrying capacity of the area, other users and fish welfare and aim to minimise local pollution and avoid spreading of diseases and protect the important genetic resources of wild stocks. In this way it will also improve the industry's reputation and increase positive public interest. In Norway a commission was set up in 2009 to propose new general principles for aquaculture site structure. Their main goal is to divide the coast into production areas for aquaculture based on the risk of spreading disease. The fish health situation is constantly monitored and presented in a yearly report by The Veterinarian Institute. It is suggested that production areas are divided into sea transfer and fallowing areas, though this is still under debate. The principles for a future aquaculture site structure will be discussed further in the forthcoming green paper on Norwegian fisheries and aquaculture policy. The Planning and Building Act, which also covers the coastal sea areas, was also completely revised and updated in 2009. It provides provisions for differentiating between main and sub-objectives. Now it is possible to designate exclusive areas to specific aquaculture species in the plans. The Act has become an important tool for resolving area conflicts in the coastal zone before concrete applications for aquaculture sites are submitted. Currently more than $90 \%$ of Norwegian coastal municipalities have spatial plans covering sea areas. We suggest that the experiences from Norway could help development in the other Nordic countries and that such principles may help to establish fish farming in the human pressured areas of the Gulf of Bothnia and the Baltic Sea.

\section{(4) Special means for the Baltic Sea area}

Goals for the Baltic Sea Recovery (BSR) presented by Dr Jouni Vielma in the Helsinki conference October 2010 is to make the area 1) environmentally sustainable; 2 ) prosperous; 3 ) accessible and attractive; and 4) safe and secure. One of the fifteen priorities of BSR strategy is to reinforce the sustainability of aquaculture, forestry and fisheries.

It has been identified and agreed upon by different stakeholders that actions like (1) compensation for nutrient removal, (2) use of Baltic Sea 
sourced feeds, (3) bigger licences for Baltic feed use and (4) bigger licences for favourable areas are useful management tools. Environmental stakeholders agreed on the usefulness of better spatial planning with others. The project AQUABEST (http://www.aquabestproject.eu/) established with fourteen partners from eight countries, funded by the Baltic Sea Region Programme, are looking into promoting the Baltic Sea region aquaculture through four development actions (Table 10).

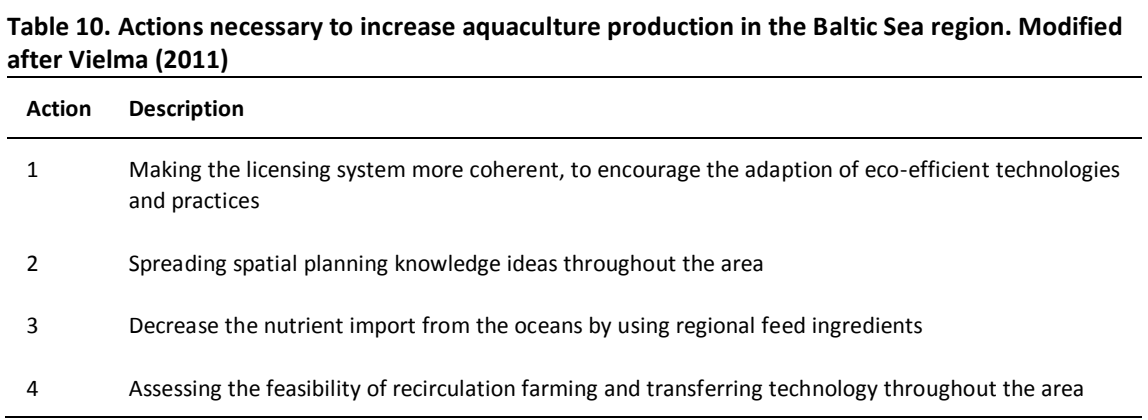

The nutrient load of fish farms is usually one of the topics that come up when discussing the Baltic Sea. In order to acquire a permit for bigger nutrient loads, different kinds of compensation for nutrient removal have been proposed, such as fishing lower value fish or using it as raw material for fish feed in the Baltic Sea region and thereby obtain a green cyclus. We foresee that the four development actions (Table 10), an implementation of the Baltic feed use model, research on its nutrient levels, manufacturing, price and its binding nature are going to be a part of the green growth approach for aquaculture. We expect that the AQUABEST project will provide more understanding for these issues.

\section{(5) New ecosystem based management}

In the future, aquaculture could be seen as an environmental service which can decrease nitrogen content in the Baltic Sea. This might boost the possibility for developing aquaculture in Sweden and Finland as a green industry. Nitrogen can be removed from the Baltic Sea by population management fishing and mussel farming. To decrease nitrogen import into the Baltic Sea, fish can be used in feed and organic waste waters as raw material in micro meals. Theoretically is it possible that $1 \mathrm{~kg}$ of farmed fish can remove $77 \mathrm{~g}$ of nitrogen, which would result in a $32 \mathrm{~g}$ net gain in fish and a $45 \mathrm{~g}$ loss which can be used to enrich oligotrophic basins. (Kiessling, 2011). In addition we anticipate that in a 30 year perspective it may be possible to manufacture large amounts of fishfeed from the nutrients of waste waters, such as sugars from pulp rinse wa- 
ter, by using microbiological fermentation. This idea was launched during the Helsinki conference (Kiessling, 2011) and points forward towards a very interesting green approach, linking the cycles between the blue and green sector.

There is apotential for freshwater aquaculture in oligotrophic hydropower basins that already have been affected in such a way that aquaculture should not decrease their ecological status, but rather increase their status by adding nutrients (Anderson, 2011). The scientific background for this is previously discussed under Perspective 2, and becomes very interesting in a green development perspective for the Baltic Sea and the Gulf of Bothnia. Sustainable rural development is on the agenda in many Nordic regions and freshwater aquaculture of niche species like arctic charr may very well be a driver for such a development. In the AQUABEST project, Jämtland in Sweden is used as the reference location for testing spatial planning in inland waters to find new places for fish farms. In Norway attention is given to the eastbound water systems found in Norwegian regions as Trøndelag and Hedemark, and assessment is under evaluation by the liaison committee for aquaculture licences in Northern Trøndelag (pers. comm. Trond Rosten,). We signalize a need for approaching these inland areas as one $A A A$ so it is possible to extract synergies across the borders.

\subsection{P6 - Domestication of new species to meet increased demand for seafood production from Nordic aquaculture}

The most important species in the Nordic aquaculture are the salmonids; Atlantic salmon, rainbow trout and Arctic charr. Nevertheless it is a paradox that production of Atlantic salmon and Rainbow trout are such successes. These species demand high water quality, they are susceptible to low oxygen, high temperature, many diseases, need space, high quality food etc. The main reasons for their success are probably linked to the easy production of juveniles which made it possible to rear the species without much complication. This has also made it easy to establish breeding programs, which has had high effects on growth rate, stress sensitivity etc. By this, Nordic aquaculture has currently only two highly domesticated species, but the Arctic charr is catching up fast through new breeding programs both in Iceland and Sweden. The dependency on salmonids is so high that we find it necessary to reccomend the introduction of at least two highly domesticated new species in the 
30y perspective. Learning from the experiences with salmonids and other species, we know that domestication takes time and a lot of effort. A joint Nordic policy agreeing on two more species in the next 30 years could make a significant impact on the ability to produce seafood. The most likely three candidates the working group see suited for full domestication are Arctic charr, cod and pike perch.

\section{Future perspectives}

In the coming years we consider it likely that Nordic aquaculture will move into these directions:

- New fish species.

- Adaptations for niche markets.

- Value adding of existing products.

- Large volume open-water or open-ocean production systems.

- High-technology recirculation systems.

The species in the Nordic aquaculture plattform are likely to be selected to fit into these directions. We discuss three of the directions (1.-3.) below. Number 4. - Large volume open-water or open-ocean production systems and high technology recirculation systems - have been discussed earlier under Perspective 4.

\section{(1) New species}

Nordic aquaculture will probably develop in a similar way as the agriculture industry. Agriculture production consists primarily of industrialized production of very few species (pig, cattle (milk) and poultry). All have been farmed for centuries. In addition there are smaller productions of specialized products and species, following a differentiation or niche strategy. In aquaculture we predict there will be a continued development with the larger producers concentrating on salmon and trout, possibly with a gradual diversification into Arctic charr, and pike perch in freshwater systems and cod in marine systems. In addition there will be continued interest in establishing productions of alternative niche species. We reccomend that this work should be encouraged and supported, but it is important to be realistic on the time and effort needed to get a new species into commercial production. 
A number of species are candidates for aquaculture production, but it is difficult to predict which species will come into commercial production, and what scale of production they could reach in the next decades. Realizing the long term committment necessary both in terms of knowledge building and capital, creates a dilemma for the decision process on which species to support development for. One possibility will be to create a financing system where the risk of establishing new productions is split between the producing companies and society.

It is remarkable that despite large efforts in establishing production of new species, very little has been achieved and production is still concentrating on the same few species. The main reasons are probably that producers, researchers and investors have grossly underestimated both time and resources needed to establish a commercially viable production. This has led to a path of bankruptcies and failed investments, which has given companies working with new species a bad image. It has not been sufficiently realized that when starting production of a new species, the raw material is a wild fish and the farmer has to compete for risk willing capital with business ideas based upon the farming of highly domesticated fish like salmon and trout. As an example, research has shown that at least $40 \%$ of the productivity in poultry, beef, pork and salmon comes from breeding programs (www.aquagen.no). For Atlantic salmon this is mediated through incresead growth rates, improved utilization of feed, increased survival and improved filet quality. This has tremendous effects on profitability and makes it difficult for new species to compete, despite often obvious advantages compared to salmon and trout, which originally were used for production primarily due to the easy production of juveniles. The problem may be solved by starting domestication programs on selected species at an early stage of commercialization, but it requires careful selection of candidate species and long-term public commitment.

During our work the workgroup have come up with a list of the most likely candidates to be developed for Nordic aquaculture. These are presented in Table 11: 
Table 11. Species foreseen to have potential to participate in the future Nordic aquaculture platform

\begin{tabular}{|c|c|c|}
\hline $\begin{array}{l}\text { Candidate } \\
\mathrm{nb}\end{array}$ & Species & Assessment \\
\hline 1 & $\begin{array}{l}\text { Atlantic salmon } \\
\text { and rainbow trout }\end{array}$ & $\begin{array}{l}\text { Established as the most important species. Fully industrialized. Will have } \\
\text { a role as the volume species in the future as well. }\end{array}$ \\
\hline 2 & Arctic charr & $\begin{array}{l}\text { High potential in northern freshwater areas. Both traditional pond } \\
\text { rearing and recirculation. Pros: Good market position (Arctic = clean), } \\
\text { rural production opportunity, robust in production, knowledge base from } \\
\text { other salmonids, many suitable locations. Cons: Possible transport } \\
\text { restrictions. Competing with other salmonids. }\end{array}$ \\
\hline 3 & Cod & $\begin{array}{l}\text { Attractive as a supplement/replacement of salmon production. Same } \\
\text { technology but different biology. Pros: High demand for white fish meat, } \\
\text { good scientific knowledge base. Cons: Fluctuating, sometimes low prices, } \\
\text { competition with other white flesh low price fish as Pangasius, Tilapia, } \\
\text { Alaska Pollock etc., expensive rearing of larvae juveniles. }\end{array}$ \\
\hline 4 & Eel & $\begin{array}{l}\text { First species in recirculation. Co-production with agriculture. Pros: High } \\
\text { demand and price, robust high density. Cons: Limited and decreasing } \\
\text { supply of glass eels, consumer image problems, risk of ban, waiting on } \\
\text { research on artificial reproduction. }\end{array}$ \\
\hline 5 & Blue mussel & $\begin{array}{l}\text { Extensive rope culture production. Pros: Simple technology, better price } \\
\text { and quality than fished mussels, nutrient reduction valuable. Cons: Low } \\
\text { and fluctuating prices, disease problems, toxic algae problems. }\end{array}$ \\
\hline 6 & Halibut and Turbot & $\begin{array}{l}\text { Attractive marine species. Long expensive history of development. Pros: } \\
\text { High price and fast growing, good scientific knowledge base. Cons: Many } \\
\text { problems in larval rearing, expensive larvae, competition with production } \\
\text { in Southern Europe. }\end{array}$ \\
\hline 7 & $\begin{array}{l}\text { Pikeperch } \\
\text { (+whitefish+perch) }\end{array}$ & $\begin{array}{l}\text { Attractive freshwater species. Suited for both extensive and recircula- } \\
\text { tion. Pros: High price, good market, suited for pond and recirculation, } \\
\text { capture fishery competing but also creating market. Cons: Many prob- } \\
\text { lems in larval rearing, ongrowing problems with diseases, stress and } \\
\text { nutrition, capture competition from Eastern Europe. }\end{array}$ \\
\hline 8 & Kelp (macroalgae) & $\begin{array}{l}\text { Interest from energy sector and chemical industry. Pros: Potential for } \\
\text { many valuable substances and energy, nutrient capture function. Cons: } \\
\text { Economic potential unresolved, competition with harvesting, lack of } \\
\text { knowledge. }\end{array}$ \\
\hline
\end{tabular}

\section{(2) Adaptations for niche markets}

The seafood and the agriculture market is divided in a low-price bulkproduct (generic) market serving the supermarket chains and a niche market for motivated consumers, hotels, restaurants etc. willing to pay a premium price for a product with a diffrent quality often in terms of "history", ecolabelling "organic" produced or having other characteristics justifying a higher price. Even the supermarket segment is increasingly demanding ecolabelling of their products.

The present production of salmon and rainbow trout is currently primarily addressing the bulk product market, but is experiencing increased competition from low price producers in Asia and Latin America. The Nordic producers have an advantage on documentation, quality 
assurance and traceability that allows for a price gain through ecolabelling. Criteria for "Organic" production are now established in Denmark and are expected to be established also in other Nordic countries.

Aquaponics is a co-production of fish and plants allowing recycling of nutrients. This technology may have resource consumption advantages when used on large scale productions and a "feel-good" branding effect when used in connection with urban areas, hotels etc and could have some oportunities as a niche.

The restaurant market (except fast food) aims at giving the consumer an "experience" or something "new". Restaurants are therefore willing to pay higher prices for alternative species. Such considerations need also to be a part of the evaluation of future species and their technology platform.

\section{(3) Value adding}

Added value may be achieved through innovative processes on existing productions. Examples are many ranging from salmonid roe now being a valuable by product sold as caviar, to tropical usually low-priced Tilapia being produced in Iceland and sold fresh at high prices in New York. Innovation is usually addressing very specific possibilities, which can be solved within a relatively short period. Such projects have relatively good possibilities for public financing, both at national and Nordic level, but cannot replace long term strategic plans for development in the aquaculture sector.

\subsection{P7 - Adaptation for a lower energy use in Nordic aquaculture}

\subsubsection{Current status}

A global reduction in energy consumption and $\mathrm{CO}_{2}$ emmison is reconnized as measures towards global warming. Energy use and climate impact from aquaculture products has been studied in several life cycle assessment (LCA) studies (Ellingsen, Emanuelsson et al. 2009; Winther, Ziegler et al. 2009; Hognes, Ziegler et al. 2011). These are all conducted on Atlantic salmon, but are considered relevant for other Nordic aquacultured species as well. Feed production is a particularly important part of energy use in aquaculture. E.g. feed production uses up to $62 \%$ of the total energy consumption in the value chain of a farmed Atlantic salmon when accounting for energy expenditure from catch and production of feed ingredients until the salmon is delivered as frozen fillet to a retailer in Paris (Figure 6). 
Product transport and transport packaging accounts for $18 \%$ and the rest is shared between processing (13\%) and the actual aquaculture rearing process $(7 \%)$. The energy use includes both direct use of fuels and electricity. Energy used in production systems underpins it with inputs of energy carriers and materials. Transport is most of the energy for some salmon products; e.g. The transport causes $80 \%$ of the energy fresh salmon to Japan by air freight. The main energy drivers in feed production is the fuel consumption during fishing and the processing from fish to meal and oil (Hognes, Ziegler et al. 2011). Compared to important wild caught seafood, like cod and herring, salmon aquaculture products use more energy, but less than pig, chicken and beef.

Figure 6. $\mathrm{CO}_{2}$ equvivalents pr kg edible product of mackrell and herring, farmed Atlantic salmon, cod, chiken, pork and beef

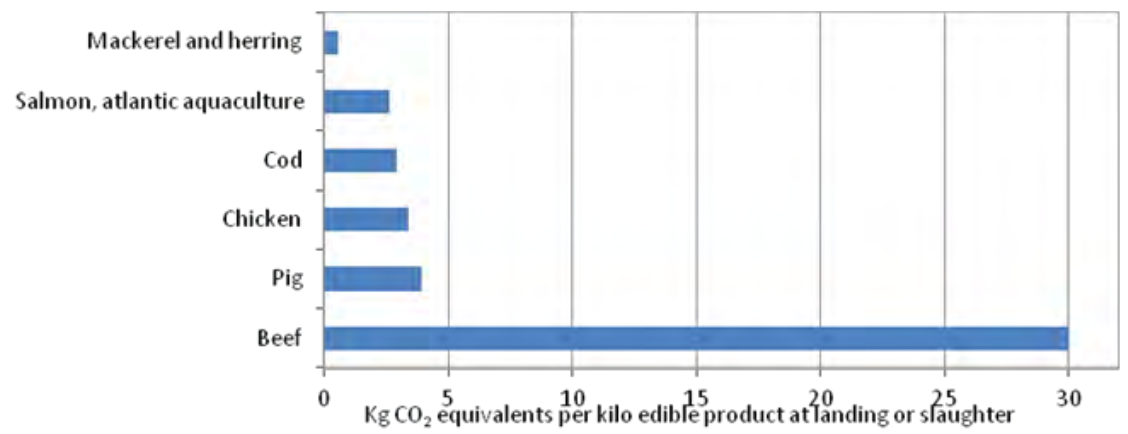

After Winther et al., 2009.

\subsubsection{Perspective of a more energy efficient aquaculture industry}

Nordic aquaculture can increase its energy efficiency by improving the utilization of the resources it depends on. This means doing more with less and using the right resource for the right purpose. Evaluation with a system perspective is neccessary to identify the possible energy improvement in the industry. The energy used per unit of seafood supplied to the consumer should be the key performance indicator. In a thirty year perspective it will be important to increase the energy efficiency of the salmon aquaculture industry. Feeds should be composed with respect to the energy use/demand of the alternative ingredient. The processes must aim for optimicing what types of energy that are used and the yields. Improvements in the biological performance in terms feed 
convertion rate and mortality is also important in this context. The cumulative energy demand and climate impact per unit of salmon ready for slaughter is the key performance indicator for the feed quality. Composing a salmon feed diet with reduced energy demand and climate impact is challenging while maintaining the nutritional requirements and paying respect to other environmental concerns. Each diet alternative must be analysed specifically as the energy use and climate impact for many important agricultural and marine ingredients are equal. Feed efficiency is the key to the energy and climate performance of the feed.

For many agricultural ingredients a final challenge is that the climate impact is not just connected to energy use, but also to the consumption of chemicals and land use.

Figure 7. Distribution of cumulative energy demand and climate impact from production of feed ingredients and till salmon is ready for slaughter

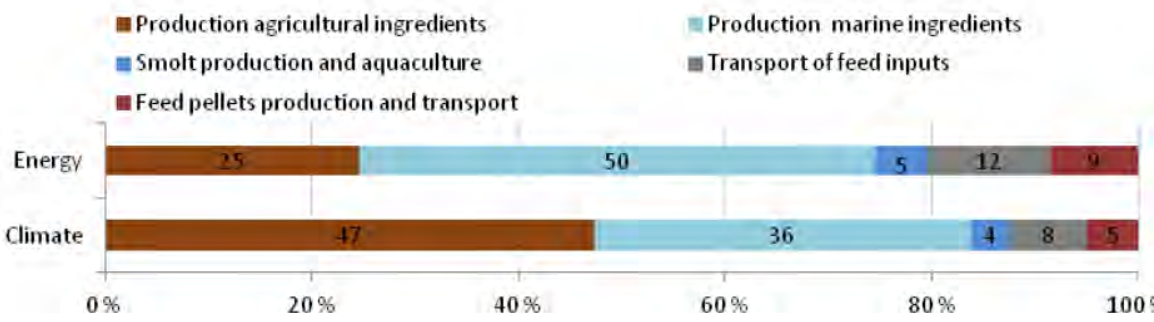

Data for average Norwegian salmon in 2010. Numbers in the graph reflect share of total for either energy use (top) or climate impact (bottom). Adapted from Hognes, Ziegler et al. 2011.

In a thirty year perspective we expect that technology for transport of fish to export markets has been improved. New freezing methods, improved temperature control and new engine and energy technology are predicted. This will lead to increased utilization of transport capacity, more products per transport unit and optimized logistics. The work group expect that export logistics changes from road to rail and from air to sea. Improved freezing technology and temperature control throughout the value chain will lead to increased shelf life and improved consumer quality of the products. The future consumer has learned, through own evaluation and documentation, that modern technology provides frozen products superior to most fresh products. Due to this, more food is expected to be consumed rather than wasted. The energy used per unit seafood will be reduced as a result. Through increased efficiency in the Nordic processing industry we predict that a high proportion of products will be exported as ready to eat products, leaving waste be- 
hind. This will increase the utilization of the export capacity, and probably boost the development of products based upon by-products. We predict that the salmon industry will become an important source of energy, provide efficient ingredients for other food and chemical industries. Some by-products might represent a higher value - per unit, than the actual fish fillet it self.

The direct energy use in the aquaculture process (grow out) is currently accounting for a minor part of the total energy consumption of the salmon. The energy used to exchange water, fishmetabolites, and respiratory gases could increase considerably if aquaculture change to more closed systems. The same scenario might hold for the construction of the fish farm. Due to this, it is neccessary to evaluate new technologies and production strategies trough a systemperspective to determine their effects on the net energy use per unit food delivered. Trade offs between increased energy use for water exchange and potential changes in feed utilization and mortality can be found.

The natural environment for off-shore aquaculture is full of renewable energy sources like waves, current and wind. The work group predict an increased utilization of these resources in the future. It is likely that aquaculture companies can increase their profitability and sustainability by developing new systems combining production of fish and energy. Wave- and current energy production is currently an immature technology, but off shore wind mills are already commercialized. Aquaculture can close the gap in energy loss comming from fish feed and become a major supplier of kelp and seaweed to bio-refineries that produce fuels, chemicals and energy. A future co-location of food and energy production is an interesting green perspective relevant for Nordic Aquaculture. The opportunity for usage of sea area for this purpose must be considered when making policies. A scenario is that the future Nordic aquaculture employees will be a highly educated human that will tackle both advanced energy-, food- and bio technology. This is concidered to be important for the future image and recruitment to the industry.

\subsubsection{Adaptation for the future perspective}

Obtaining a more energy efficient aquaculture industry will be a result of many small achievements throughout the whole value chain. The net sum of energy used per unit food delivered, is one key performance indicator for Nordic aquaculture industry. By this fact, the development of the framework of policies, regulations and legislations, must be developed with respect to their effect on energy use. Holistic and systematic 
methods, like e.g. life cycle assessment (LCA), could be used to evaluate environmental effects of policies. A comprehensive study on the energy usage and climate impact of Nordic aquaculture production technologies would be valuable background for future policies concerning lowering energy consumption. The development of future technology for colocating food and energy production is considered a green growth opportunity we can't let go. It is recommended to reflect this in both national research programs and in Nordic research coordination through instruments like Nordforsk and Nordic Innovation.

Figure 8. Distribution of energy use from catch and growing of feed ingredients and till salmon is delivered as frozen fillet to retailer in Paris by truck

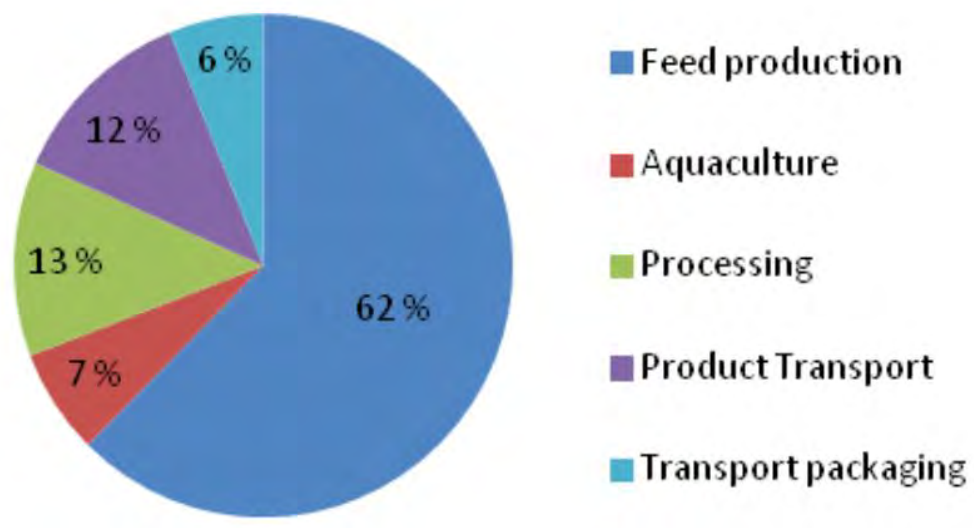

Total cumulative demand was 40,7 MJ per kg edible salmon. Adapted from Winther, Ziegler et al. 2009. 



\section{Recommendations}

In the following we sum up some of the findings we assess as the most important for developing policy's and measure for a green growth of Nordic aquaculture. For detailed background and ideas approaches see chapter 3 (Perspectives for further development of sustainable aquaculture). The list is non-prioritized.

- Aquaculture in the Nordic countries must be recognized and communicated as an important and necessary industry for the sustainable production of food in a global perspective, treated equally with other primary food production sectors. The image of the industry is a mutually shared problem across the Nordic countries, possibly affecting recruitment and the possibilities for development.

- The Nordic countries must establish a policy for adaptations to future feed source constraints which may imply improved use of low trophic resources such as microalgae, krill and calanus, whole carcass and byproducts from fishery and aquaculture industry and agriculture products.

- An acceptance of the principle to move nutrients from the eutrophicated Baltic sea to oligotrophic water power dams. The "Robin Hood principle" must be established. The production of a locally based feed from the Baltic Sea could boost the opportunities for inland aquaculture of Arctic charr and rainbow trout, and at the same time give positive ecosystem effects both in the Baltic Sea overloaded with nutrients and in water power dams suffering from nutrient depletion.

- In the Nordic countries, there are good possibilities to link cycles in Nordic blue and Nordic green sectors by utilizing waste from paper mills for bio-technological facilitated production of proteins for fish feed and on land aquaculture stations. The current potential for fish production based on these non-food resources are estimated to be > 1 million tons fish. 
- The Nordic countries should note that phosphorous is important for food production and a global phosphorus crisis is predicted in the near future. An adaptation for better use and collection of phosphorous is therefore recommended in all food production systems. By taking such a step the Nordic countries would take a global lead in this field, The aquaculture sector could adapt to collect and reuse discharged phosphorous through "catch" organism such as kelp and blue mussels and establish technologies and practices that collect wasted feed and faeces for refining were such are applicable.

- The Nordic countries should identify that sludge collected from land based fish farms represents an important source of carbon that would be attractive for bio-fuel production and the development of systems for logistics and production is recommended. This represent a possibility to further link ble and green sector, since the residues from bio-fuel production are fertilizers. An adaptation for better use and collection of carbon is recommended in all food production systems. By taking such a step the Nordic countries would take a global lead in this field. Future technology development might improve the possibility to collect sludge also from floating aquaculture farms.

- The Nordic countries should accept that discharge of nutrients from aquaculture into suited oligotrophic water systems (water power magazines) is one way of improving the ecological status and increasing food production in rural areas. A cooperation of inland aquaculture development in a Nordic east/west axis is recommended.

- Potential for developing more advanced industries based upon byproducts from aquaculture and fisheries needs to be recognized and should be encouraged by activities in research and innovation instruments (e.g. Nordforsk, Nordic Innovation) the Nordic countries. Utilizing the whole carcass and waste for the production of food, (health food, functional food), pharmaceuticals and feed (protein, oils, minerals), is predictyed to boost the value of the fish. Given the right focus a blooming new industry can be developed in this field and thereby give standards for other regions.

- To realize the full potential for aquaculture in the Nordic countries there is a need for further development of new and already existing technologies and operations suited for production in marine, freshwater and land based systems. 
- The Nordic countries should develop the technologies for off-shore farming through joint efforts. Focus ought be development of materials, systems and operations that can withstand more exposed sites and eliminate problems with escapees, sea lice and systems that can be used in combination with production of algae, kelp or mussels (catchcrop) should prioritized.

- The Nordic countries should develop land based systems through joint efforts. Focus ought to be on development of RAS, bringing down the investment and energy costs, make economy of scale possible, obtain viable systems for the cleaning of the internal waterflow and collection of nutrients and carbon in the discharge.

- The Nordic countries should develop inland aquaculture through joint efforts. Focus ought to be on materials, systems and operations that can withstand ice and eliminate problems with escapees along with ecosystem effects. Policy's that stimulates cooperation across the Nordic boarders is reccomended to strengthen the development of inland aquaculture.

- To maintain the growth possibilities, the Nordic countries should with their joint research and innovation intruments focus on developing technologies for solving problems with salmon lice. E.g. development of farming technology, vaccine, biological delousing using wrasse large scale delousing mechanical, electrical fences).

- Food production from aquaculture in the individual Nordic countries or regions could be boosted by focusing on the following areas and measures:

a) The Baltic Sea: Space planning, local feed supply, simplification of regulations and adoption of ecosystem approach and IMTA.

b) Sweden and Interregional areas on both sides of the Norwegian/Swedish boarder. Identification and organizing of freshwater systems suitable for inland farming of Arctic charr or rainbow trout in Sweden and boarder communities in Norway (with eastbound water systems, or power magazine), cooperation about Arctic charr breeding program and licensing policy.

c) Denmark: Change from feed quotas regulations to nitrogen quotas to allow tradable Nitrogen-quotas with the agriculture industry, IMTA, new species. 
d) Finland: Enabling consolidation of cage farms into bigger units in less sensitive locations. Exclusion of indirect production limitations in regulation. New species.

e) Iceland: Increase production of Arctic charr based upon competitive advantages with geo-thermal and geo-filtered water sources. Technologies for offshore farming of salmon and aquaculture of new species based on Icelandic warm water reservoirs and other underutilized energy resources.

f) The Faroe Islands: Utilizing existing potential for the production of salmon, possible also expansion with offshore farming of salmon, IMTA.

g) Norway : Utilization of existing potential for the production of salmon and rainbow trout, sterile salmon, off-shore farming, IMTA, adaptation in production cycles, new measures against salmon lice and escapes.

- New species might hold the key to secure future growth of aquaculture in Nordic Areas. To enable this one must recognize the time needed to domesticate a species for aquaculture. We recommend that the Nordic countries, amongst each other, should at aim for the industrialization of two more industrialized species in a thirty year time span. 


\section{Referanser}

Aarhus, I. J., Høy, E., Fredheim, A., Winther, U. 2011. Kartlegging av ulike teknologiske løsninger for å møte de miljømessige utfordringene i havbruksnæringen - SINTEF rapport F18718.: SINTEF Fisheries and Aquaculture.

Andaur, K., Olsen, T.O., Molvik, G., Sveier, H., Williksen, T., Winther, U., Åtland, Å., Elvevoll, E. 2012. Fremtidens lakseoppdrett (Rapport 01 2012). In: FIXDAL, J. (ed.). Oslo: Teknologirådet.

Andersson, J. 2011. Potential and limitations of aquaculture in freshwater systems. Conference on Competitive and Sustainable Aquaculture. Dimensions and Tools of Competitive and Sustainable Aquaculture in Northern Europe. Helsinki, Finland.

ASCHE, F., BJøRNDAL, T., 2011. The Economics of Salmon Aquaculture, Chichester., Wiley-Blackwell.

Bergheim A., Sanni S., Indrevik G., Holland P., Sludge removal from salmonid tank effluent using rotating microsieves, Aquacult. Eng. 12 (1993) 97-109.

Bryde, M. 2011. Marine spatial planning and aquaculture - a Norwegian perspective. Conference on Competitive and Sustainable Aquaculture. Dimensions and Tools of Competitive and Sustainable Aquaculture in Northern Europe. Helsinki, Finland.

C. Young Cho \& Dominique P. Bureau (1997): Reduction of Waste Output from Salmonid Aquaculture through Feeds and Feeding, The Progressive Fish-Culturist, 59:2, 155-160

C. Young Cho \& Dominique P. Bureau (1997): Reduction of Waste Output from Salmonid Aquaculture through Feeds and Feeding, The Progressive Fish-Culturist, 59:2, 155-160

Cordell, D., Rosemarin, A., Schröder, J.J. \& Smit, A.L. (2011), Towards global phosphorus security: A systemic framework for phosphorus recovery and reuse options. Chemosphere, Special Issue on Phosphorus. DOI:

10.1016/j.chemosphere.2011.02.032

Cordell, D., White, S. And Lindström, T. (2011) Peak phosphorus: the crunch time for humanity?, The Sustainability Review journal, Issue 2, Research Vol 2, Apr 4th 2011.

Crampton, V.O., Nanton, D.A., Ruohonen, K., Skjervold, P.-O. And El-Mowafi, A. 2010, Demonstration of salmon farming as a net producer of fish protein and oil. Aquaculture Nutrition, 16: 437-446.

Dørum, Ø. 2012. Presentasjon fra sjefsøkonom Øystein Dørum, DNB under FHLs generalforsamling i mars 2012.

Ellingsen, H., A. Emanuelsson, Et Al. (2009). Prosjektrapport: Energibruk og klimautslipp i eksport av norsk sjømat http://skala.sintef.no/Content/ publikasjonsbase/publikasjon.aspx?pubid=SINTEF+A19097.

Garcia, S. M., Rosenberg A. A., 2010. Food security and marine cap-ture fisheries: characteristics, trends, drivers and future perspectives (doi: 10.1098/rstb.2010.0171) Philosophical transactions of the royal society, 28692880 . 
Handå, A., Forbord, S., Broch, O.J., Richardsen, R., Skjermo, J., Reitan, K.I. (2009). Utredning om dyrking og anvendelse av tare, med spesiell fokus på bioenergi i nordområdene. SINTEF.

Hansen, J. Ø., Shearer, K.D., Øverland, M. Penn, M.H., Krog-Dahl, Å., Mydland, L.T., Storebakke, T. 2011. Replacement of LT fish meal with a mixture of partially deshelled krill meal and pea pro-tein concentrates in diets for Atlantic salmon (Salmo salar). Aquacul-ture 315: 275-282.

Heip, C. 2011. Climate Change and Marine Ecosystem Research - Syn-thesis of European Research on the Effects of Climate Change on Ma-rine Environments. In: Calewaert, J.-B., Heip, C, Mcdonough, N., Philippart, C. (ed.) Marine Board Special Report. Marine Board.

Hjeltnes, B., Baeverfjord, G., Erikson, U., Mortensen, S., Rosten, T., Øs-tergård, P., 2012. Risk assessment of recirculation systems in salmonid hatcheries. Norwegian Scientific Committee for Food Safety VKM 09/808

Hjeltnes, B., Bæverfjord, G., Erikson. U., Mortensen, S., Ros-Ten, T.W., Østergård, P. 2012. Risk Assessment of Recirculation Systems in Salmonid Hatcheries. Oslo: Norwegian Scientific Commit-tee for Food Safety

Hognes, E. S., F. Ziegler, Et Al. (2011). Carbon footprint and area use of farmed Norwegian salmon www.sintef.no/Publikasjoner-

SINTEF/Publikasjon/?pubid=SINTEF+A22673, SINTEF Fisheries and aquaculture. KIESSLING, A. 2009. Feed - the key to sustainable fish farming. In: Fisheries, sustainability and development (eds: Ackefors, H. \& Wramner P.). Royal Swedish Academy of Agriculture and Forestry. Pp. 303-322.

Kristensen, T., Atland, A., Rosten, T., Urke, H. A. \& Rosseland, B. O. 2009. Important influent-water quality parameters at freshwater production sites in two salmon producing countries. Aquacultural Engineering, 41, 53-59.

Ministry Of Fisheries And Coastal Affairs 2009. Strategi for en miljømessig bærekraftig havbruksnæring. Oslo: Fiskeri og Kystde-partementet.

Naylor, R.L., Hardy, R.W., Bureau, D.P., Chiu, A., Elliott, M., Farrell, A.P., Forster, I., Gatlin, D.M., Goldburg, R.J., Hua, K., And Nichols, P.G., 2009. Feeding aquaculture in an era of finite re-sources. Proc Natl Acad Sci USA 106:15103-15110Norwegian Scien-tific Committee for Food Safety 2009. Criteria for safe use of plant ingredients in diets for aquacultured fish. $106 \mathrm{pp}$.

Nielsen, R. 2012. Barriers to Sustainable Growth in the Aquaculture Sector: An Economic Analysis PhD, University Of Copenhagen.

Nordisk Ministerråd 2011. Norden - ledande i grön tilväkst. Rap-port från de nordiska statministranas arbetsgrupp för grön tilväxt. Köbenhamn: Nordisk ministerråd.

OECD 2011. A green growth perspective on aquaculture (TAD/FI 2011) 8/PART4/REV. Trade and Agriculture Directorate Fisheries Commitee.

OECD 2011a. Towards Green Growth: Green Growth Strategy Synthe-sis Report (OECD C/MIN(2011) 4.). OECD

Reve, T. \& Sasson, A. 2012. Et kunnskapsbasert Norge, Oslo, Univer-sitetsforlaget.

Richardsen, R. 2010. Norsk marin ingrediensindustri. Struktur og lønnsomhet 20072010 (SINTEF rapport A21511). Trondheim: SIN-TEF Fiskeri og havbruk.

Rosten, T. W., Ulgenes, Y., Henriksen, K., Terjesen, B.F., Bie-Ring, E., Winther, U. 2011. Oppdrett av laks og ørret i lukkede an-legg - forprosjekt FHF (Sintef rapport A21169). Trondheim: Sintef Fiskeri og havbruk AS. 
SHE, J. 2011. Impacts of Climate Change on the Baltic Sea. In: HEIO, C. (ed.) Climate Change and Marine Ecosystem Research - Synthesis of European Research on the Effects of Climate Change on Marine Envi-ronments. Marine Board.

Simon J. Cripps *, Asbjørn Bergheim. 2000. Solids management and removal for intensive land-based aquaculture production sys-tems. Aquacultural Engineering 22; 33-56.

Tacon, A.G.C., Hasan, M.R., Metian, M. 2011. Demand and supply of feed ingredients for farmed fish and crustaceans. Trends and pro-spects. FAO Technical paper 564. $87 \mathrm{pp}$.

Taranger, G.L., Svåsand, T, Madhun, A.,S., Boxaspen, K.K. (2011) Risikovurdering av Norsk Fiskeoppdrett. Pressekonferanse 13.01.2011 pp 1-24.

Torrissen, O., Olsen, R. E., Toresen, R., Hemre, G. I., Tacon, A. G. J., Asche, F., Hardy, R. W., Lall, S. P., 2011. Atlantic Salmon (Salmo salar) - The Super-Chicken of the Sea? Reviews in Fisheries Science, 19, 257-278.

Vielma, J. 2011. Bottlenecks in the Baltic Sea region aquaculture and their potential solutions. Conference on Competitive and Sustainable Aquaculture. Dimensions and Tools of Competitive and Sustainable Aquaculture in Northern Europe. Helsinki, Finland.

Winther, U., F. Ziegler, Et Al. (2009). Project report: Carbon foot-print and energy use of Norwegian seafood products www.sintef.no/Fiskeri-og-HavbrukAS/Prosjekter/2011/Miljoregnskap-og-klimasporing-av-sjomat/. Trondheim, Norway, SINTEF Fisheries and aquaculture.

Winther, U., Sandberg, M.G., Richardsen, R., Olafsen, T., Kongsvik, R.B., Hauvik,J.H., 2011. Potensial for økt verdiskapning i lakse og ørretsoppdrettsnæringen SINTEF rapport A19458. Trond-heim: SINTEF Fisheries and Aquaculture.

Statistics from the RUBIN Foundation, The Danish AgriFish Agency, The Finnish Game and Fisheries Research Institute's, The Icelandic Aquaculture Association, Faroese Bureau of Statistics, production figures from Sweden. 



\section{Sammendrag}

I løpet av 2012 har en Nordisk arbeidsgruppe bestående av eksperter fra Danmarks Tekniske Universitet (DTU), Sveriges landbruksuniversitet (SLU), Finnish Game and Fisheries Research Institute (RKTI), Matis Ltd, SINTEF Fiskeri og havbruk AS (SINTEF) kommet frem til 7 forslag til perspektiver (P1-P7) på grønn vekst for akvakultur i Norden:

P1 Tilpasninger til en fremtidig mangel på marine fôrressurser.

P2 Tilpasninger til bærekraftig bruk og gjenbruk av karbon, fosfor og nitrogen.

P3 Tilpasninger for å skape merverdi basert på utnyttelse av biprodukter.

P4 Teknologiutvikling som muliggjør å utnytte akvakultur potensialet.

P5 Styrke konkurransekraft i områder attraktive for akvakultur.

P6 Domestisere nye arter for å møte økt etterspørsel etter sjømat.

P7 Tilpasninger til et redusert energiforbruk i akvakultur.

Arbeidet med rapporten har skjedd i samarbeid med en referansegruppe oppnevnt av Nordisk Ministerråd for Fiskeri og Havbruk, Jordbruk, Næringsmidler og Skogbruk (MR-FJLS) og resultater fra arbeidet ble presentert på konferansen Green Growth Nordic i juni 2012 (http://www.greengrowthnordic.no/). Arbeidet bygger på faglige diskusjoner i ekspertgruppen, gjennomgang og analyser av offisiell statistikk, industrirapporter og vitenskapelige publikasjoner, samt direkte innspill formidlet gjennom referansegruppen. De enkelte perspektiver (P1-P7) er omtalt i detail i rapporten. Perspektivene er i all hovedsak lagt i en tredveårs horisont. Nedenfor gis en meget kort oversikt over de viktigste momentene i hvert perspektiv etterfulgt av arbeidsgruppens anbefalinger.

P1 Tilpasninger til en fremtidig mangel på marine fôrressurser Marint fôrråstoff er en begrenset ressurs og økende efterspørsel efter fiskemel og særlig fiskeolje. I et grønn vekst perspektiv, må de ville fiskepopulasjonene forvaltes bærekraftig. Dersom nordisk akvakultur skal kunne vokse, må alternative fôrråstoff kilder utvikles. Det kan være flere 
utfordringer ved bruk av ikke marine protein- og oljekilder, både i forhold til energiregnskap, kvalitet på fôret med tanke på ytelse (fiskehelse og vekst), samt sluttkvalitet til forbruker. Et underliggende spørsmål er kostnader med å bruke eller utvikle nye fôrkilder. Arbeidsgruppen finner det ikke sannsynlig at det skal utvikles oppdrett med plante-etende fiskearter i Norden, men tror at forskning og utvikling vil muliggjøre økt bruk av restråstoff eller fôrkilder av vegetabilsk-, mikrobiell- eller planktonisk opprinnelse. Bedre utnyttelse av restråstoff fra allerede ilandførte biomasser fra fiskeri kan også bidra til grønn vekst. Det er allerede en høy kunnskapsplattform i Norden innen forskning på fôr til de aktuelle oppdrettsartene og arbeidsgruppen ser at det viktig å bygge på denne.

\section{P2 Tilpasninger til bærekraftig bruk og gjenbruk av karbon, fosfor og nitrogen}

Det er muligheter for grønn vekst ved å utnytte ressurser i slam fra fiskeoppdrett. Karbonet vil kunne utnyttes i biogassproduksjon og næringssaltene som gjødsel eller jordforbedringsmiddel. Arbeidsgruppen retter særlig oppmerksomheten mot fosfor som er en global begrenset ressurs og som bør gjenvinnes der det er mulig. Som ved annen animalsk matvarevareproduksjon, vil det være en gjødselproduksjon (slam) fra fiskeoppdrett som er proposjonal med fôrforbruket. I hvilken grad dette slammet bidrar til å forbedre eller forringe vannmiljøet er avhengig av lokale forhold. I et nordisk perspektiv har man ulike utfordringer i de aktuelle oppdrettsområdene med tanke på utslipp av nitrogen og fosfor. Dette kan få betydning både for lokale tilpasninger i reguleringsregime og teknologivalg.

\section{P3 Tilpasninger for å skape merverdi basert på utnyttelse av biprodukter}

Det landes store mengder villfisk og det produseres mer enn 1 million tonn oppdrettsfisk i de Norden. Mesteparten av restproduktene fra den marine siden utnyttes i dag, men arbeidgruppen påpeker at ytterligere grønn vekst kan muliggjøres på bakgrunn av disse biomassestrømmene. Avansert foredling i kombinasjon med markedsutvikling kan gi muligheter for nye produkter innenfor en rekke markeder. Økt utnyttelse av biproduktene henger også sammen med tilpasninger innenfor perspektiv 1, der utfordringen med begrensede marine fôrressurser påpekes. 


\section{P4 Teknologiutvikling som muliggjør å utnytte akvakultur potensialet}

Det er et stort potensial for akvakultur i Norden. En videre utvikling av akvakultursektoren bør imidlertid basere seg på at de regionale miljømessige utfordringene løses, herunder problemstillinger med villlaks i Vest-Norden og eutrofi i Øst og Sør-Norden. Laksefisk vil, om ikke alene, utgjøre den store biomassen i den nordiske akvakulturplattformen også $i$ et 30 års senario og det er viktig å legge til rette for forskning og utvikling på et nordisk plan for å sikre dette. Teknologisk og biologisk har vi kommet lengst med laksefiskartene, og sannsynligheten for å videreutvikle teknologiske løsninger for de gjenstående miljøutfordringer vil være størst med disse.

\section{P5 Styrke konkurransekraft i områder attraktive for akvakultur}

Det er et betydelig behov for tiltak for å styrke konkurransekraften i de nordiske områdene attraktive for akvakultur. Det er ulike tiltak som må settes inn i de forskjellige områdene avhengig av hvilke områder som hindrer vekst og utvikling. Rapporten påpeker særskilte tiltak for de ulike nordiske land i kraft av de regionale utfordringene. Arbeidsgruppen mener at nordisk akvakultur kan styrkes ved å tilrettelegge for erfaringsoverføring fra områder med en utviklet akvakulturforvaltning til områder der slik sektorforvaltning fortsatt er under utvikling.

\section{P6 Domestisere nye arter for å møte økt etterspørsel etter sjømat}

Akvakultur i de nordiske landene må forventes, også i fremtiden i stor grad å dreie seg om oppdrett av laksefisk, herunder artene; atlantisk laks, regnbueørret og arktisk røye. Av disse er det bare atlantisk laks og regnbue ørret som anses som fullt ut domestisert og industrialsert. Det synes klart for arbeidsgruppen at arktisk røye har et godt potensial for bli den tredje industrialiserte art, men anbefaler at man gjennom felles nordisk innsats tar frem minst en art til industrialisert nivå og at dette er en hvitfisk. I et fremtidsscenario på 30 år vil det også være plass til en rekke andre nisjearter, men disse tror man i mindre grad vil bidra til å produsere de større biomassetrømmer som er viktige for grønn vekst.

\section{P7 Tilpasninger til et redusert energiforbruk i akvakultur}

Dokumentasjon på energiforbruk og klimaavtrykk innenfor akvakultur bygger i stor grad på oppdrett av Atlantisk laks. Det vil være behov for å analysere klimaspor på andre oppdrettarter og teknologi. I sammenlignende studier kommer oppdrettet laks bedre ut klimaspormessig enn svinekjøtt og oksekjøtt, men noe høyere enn pelagisk fisk. Mesteparten av klimaavtrykket kommer fra fiskefôret, så med økt bruk av alternative 
fôrkilder for protein eller olje bør man undersøke disse med tanke på klimaeffekter når de erstatter råstoff fra marine kilder. I et fremtidscenario bør energiforbruket på transport til sluttmarkeder kunne avta, ettersom økt foredlingsgrad forventes før pakking og utskiping. Ny teknologi på frysing og pakking vil også kunne påvirke klimasporet gjennom mer effektiv transport, lengre hylletid og redusert utkast.

\subsection{Anbefalinger fra arbeidsgruppen}

Nedenfor omtales noen av de anbefalinger arbeidsgruppen trekker opp for viderutvikling av bærekraftig nordisk akvakultur. For en punktvis oppstilling henvises til kapitel "Recommendations" i rapporten.

\subsubsection{Anerkjennelse og omdømme for akvakultursektoren}

Først og fremst må akvakultur i de nordiske landene bli anerkjent som en viktig og nødvendig næring for bærekraftig produksjon av mat. Arbeidet med å etablere et positivt omdømme for denne industrien, bør skje $i$ et felles nordisk perspektiv siden det er flere synergier og koblinger mellom landene. Akvakulturnæringen bør behandles likt med andre primære matproduksjonsnæringer. Industriens til dels svake omdømme synes å være et gjensidig felles problem i Norden, og det er sannsynlig at dette påvirker rekruttering og mulighetene for utvikling. Det ligger imidlertid store muligheter for grønn vekst innen denne sektoren, dersom man lykkes å arbeide med tilpasninger rundt de syv perspektivene (P1-P7).

\subsubsection{Fôrressurser en nøkkelfaktor}

Det må etableres en politikk for tilpasninger innen akvakultur til forventede, begrensede marine fôrressurser. Fiskeolie og fiskemel er i dag hovedingredienser i fiskefor, men anvendelsen av disse ressursene er under økende press, både økonomisk i form av stigende priser og politisk i form av ønsker om i høyere grad å beskytte de marine økosystemer og anvende ressursene direkte til humant konsum. Det er intressant å høste ressurser på et lavere trofisk nivå i næringskjeden, herunder mikroalger, krill og calanus. Det kan også omfatte tilrettelegging for økt bruk av restråstoff fra fiskeri- og havbruksnæringen, samt landbruksprodukter i fiskefôret. Tiltak for å støtte opp om utvikling av potensielt nye fôrkilder fra eksempelvis tare og encellebiomasse anbefales. 


\subsubsection{Se næringsrike og næringsfattige områder $\mathrm{i}$ sammenheng}

Den store biomasseproduksjonen innen oppdrett forventes fortsatt å skje i havet i Norge, Færøyene og Island, men de nordiske landene kan også iverksette tiltak som kan muliggjøre utvikling av innlandsoppdrett, landbasert oppdrett og oppdrett i Østersjøen. Det bør etableres en politisk aksept av prinsippet med å flytte næringsstoffer fra næringsrike (eutrofe) områder (som for eksempel Østersjøen) til næringsfattige (oligotrofe) vassdrag (som f.eks vannkraft dammer) ved bruk av oppdrettsanlegg. Tilrettelegging for fôrproduksjon basert på planktonspisende fisk fra Østersjøen kan øke mulighetene for økosystemtjenester fra oppdrett. Man kan gjennom slike tiltak oppnå positive økosystemeffekter både i Østersjøen og i næringsfattige innsjøer.

\subsubsection{Muligheter mellom grønn og blå sektor}

En ny og spennende mulighet for grønn vekst er å knytte sammen produksjonssykluser fra grønn og blå sektor ved å stimulere til forskning og utvikling på produksjon av proteiner til fiskefôr på restprodukter fra papirindustrien ved å benytte mikroorganismer. Et potensial for å produsere fôr til mer enn 1 million tonn fisk er blitt forelagt arbeidsgruppen.

I en grønn vekst tankegang må det rettes større oppmerksomhet mot en forestående global fosformangel. Mangel på uorganisk fosfor truer verdens matvareproduksjon. Politikk og tiltak som kan være med å sikre $\varnothing \mathrm{kt}$ fangst og gjenbruk av fosfor fra utslipp fra fiskeoppdrett vil gjøre de nordiske landende til forgangsland på dette feltet. En tilpasning for bedre bruk og innsamling av fosfor er anbefalt i alle produksjonssystemer for mat. Det er viktig for omdømmet at akvakulturindustrien også bidrar. Innenfor havbruk forutser man at det kan være mulig å gjenvinne fosfor og nitrogen blant annet ved høsting av naturlige bestander av tare, blåskjell, bunndyr eller aktivt dyrke disse i tilknytning til oppdrettsområder (såkalt "catch crop"). Dersom man lykkes med utvikling av flytende lukkede oppdrettsanlegg, kan man sannsynligvis kunne etablere systemer for partikkelfangst som giør det mulig å gjenvinne enda mer fosfor og karbon.

Slam samlet inn fra landbaserte oppdrettsanlegg representerer en ny mulighet for grønn vekst. Denne ressursen inneholder store mengder karbon og næringssalter (inkludert fosfor), som er attraktivt for produksjon av henholdsvis biodrivstoff og gjødsel. Politikk og stimuli for å utvikle systemer for logistikk og produksjon av biogass og gjødsel fra fiskeslam anbefales. Dette representerer nok en mulighet der blå- og grønn 
sektor kan knyttes bedre sammen. Innblanding av fiskeslam i husdyrmøkk før biogass produksjon virker lovende og økt utnyttelse av biorest fra biogass produksjonen til gjødsel er god ressursutnyttelse.

\section{Biprodukter - grunnlag for industri}

Potensialet for grønn vekst basert på biomassestrømmer/biprodukter fra fiskeri og havbruk er stort. Det forventes at det er gode muligheter for å utvikle mer avanserte produkter basert på biprodukter. Skal man lykkes bør man politisk tilrettelegge for forskning og innovasjon innenfor biprodukt området. Dette kan på overordnet Nordisk grunnlag prioriteres gjennom instrumenter som f.eks Nordforsk og Nordic Innovation. Utnyttelse av biprodukter til produksjon av mat, (helsekost, funksjonell mat), farmasøytiske produkter og ingredienser både til fôr og mat (protein, oljer, mineraler) vil øke verdien av fisken og næringen og sannsynligvis bidra til bedre omdømme. Arbeidsgruppen tror at nye næringer kan utvikles på dette feltet og dermed sette standard for andre oppdrettsområder i verden.

\section{Teknologiutvikling}

For å kunne utnytte det fulle potensialet for akvakultur i Norden, er det behov for videre utvikling av både nye og eksisterende teknologier egnet for produksjon i marine, ferskvann og landbaserte systemer. Det bør tilrettelegges for nordisk samarbeid og forskning, blant annet gjennom instrumenter som Nordforsk og Nordic Innovation for å utvikle teknologier for off-shore havbruk for å sikre de store biomassestrømmene fra oppdrett av atlantisk laks. Fokus bør være utvikling av materialer, systemer og operasjoner som kan tåle mer eksponerte lokaliteter, samt fjerne problemer med rømming og lakselus. Systemer som kan brukes i kombinasjon med høsting eller produksjon av alger, tang eller blåskjell ("catchcrop") bør prioriteres. Oppdrettsnæringen i Norden er avhengig av en god teknologi og sterk leverandørindustri for landbasert oppdrett av de første fasene av laksefiskproduksjon og for oppdrett av godt betalte nisjearter av både marin- og ferskvannsopprinnelse. Det bør tilrettelegges for nordisk samarbeid for å videreutvikle landbaserte oppdrettssystemer til anvendelse for laksesmolt og nisjearter. Fokus bør være på utvikling av bedre resirkuleringssystemer (RAS), herunder utvikling av RAS som kan få ned investerings- og energikostnaden, muliggjøre stordriftsfordeler, ha forbedrede systemer for intern vannbehandling, samt fangst av næringsstoffer og karbon fra utslippet. Innenfor innlandsoppdrett bør fokus være på materialer, systemer og operasjoner som tåler is og fjerner potensielle problemer med rømming og eventuelle økosys- 
temeffekter. Et samarbeid på Nordisk plan om utvikling av innlandsoppdrett som et godt supplement til havbruk anbefales.

\section{Satse på få arter}

De viktigste biomassestrømmene i nordisk akvakultur bygger på oppdrett av atlantisk laks, regnbueørret og arktisk røye. Bare atlantisk laks og regnbueørret kan sies å være fullt ut industrialiserte. Ved siden av grønn vekst med utgangspunkt i de eksisterende laksefiskartene, kan nye oppdrettsarter være en viktig nøkkel til å sikre fremtidig vekst av akvakultur i de nordiske områdene. For å realisere dette, må man politisk erkjenne og prioritere den tiden og de ressurser som trengs for å domestisere en art for akvakultur. På et mer generelt grunnlag anbefaler vi at de nordiske landene i fellesskap bør ha som mål å industrialisere to nye oppdrettsarter i et tretti års perspektiv. Mye tyder på at den ene av disse er Arktisk røye, men at den andre bør være en hvitfisk med enten marin- eller ferskvannsopprinnelse. Gruppen anerkjenner og ser viktigheten av utvikling av nisjearter i tillegg til de hovedartene som skal utgjøre den generiske biomasseproduksjonen. Disse kan være av både marin- og ferskvannsopprinnelse.

\section{Regionale innspill}

Matproduksjonen fra akvakultur i de enkelte nordiske regioner kan bli styrket ved å fokusere på spesifikke geografiske tiltak. Det vil også gi nye biomassestrømmer som kan utnyttes til grønn vekst. Rapporten foreslår følgende fokusområder for å muliggjøre dette:

- Østersjøen:

Akvakultur produksjonen kan økes ved bedre areal planlegging, lokal forsyning av fiskefôr, forenkling av regelverk, økosystemtilnærming i forvaltning, samt ved bruk av catchcrops.

- Sverige og interregionale områder på begge sider av den norsk / svenske grensen:

Identifisering og organisering av ferskvannskilder som er egnet for innlands oppdrett av røye og/eller regnbueørret. Grenseområder med felles vassdragssystemer kan med fordel ses i sammenheng. Nordisk samarbeid på avlsprogram og konsesjonspolitikk på røye oppfordres. 
- Danmark:

Grønn vekst kan oppnås ved endring i reguleringsregime fra fôrkvoter til nitrogen/fosfor kvoter Denne prosess er allerede i gang. En politikk der det det vil være mulig med omsettelige nitrogen/fosfor-kvoter mellom landbruk og oppdrett anbefales. Tiltak som øker mulighet for offshore havbruk, integrert multitrofisk havbruk (IMTA), oppdrett av nye nisjearter representer også gode muligheter.

\section{- Finland:}

Aktiv konsolidering av oppdrettsanlegg i større og mer funksjonelle enheter på mindre følsomme steder (gode lokaliteter) vurderes som det viktigste tiltak. Endring av indirekte begrensninger i reguleringer slik at dette kan muliggiøres anbefales. Det vil også være muligheter innen produksjon av nye arter.

- Island:

Øke produksjonen av røye i landbaserte anlegg basert på konkurransefortrinn med geo-termisk og geo-filtrert vann kilder. Teknologisk utvikling med tanke på offshore oppdrett av laks og oppdrett av nye arter basert på de lokale energiressursene.

- Norge:

Utnytte de nasjonale fortrinn for havbruk med produksjon av atlantisk laks og regnbueørret. En god og sikker grenseflate mot vill atlantisk laks må oppnås. Veien mot grønn vekst kan derfor gå gjennom utvikling av steril laks, off-shore havbruk, rømmingssikre anlegg og operasjoner, bruk av "cathcrops", lengre smoltfase på land, samt nye løsninger mot lakselus.

\section{- Færøyene:}

Utnytte de nasjonale fortrinn for produksjon av laks. Videre utvikling ved utvidelse med off-shore oppdrett av atlantisk laks gjerne i kombinasjon med bruk av "catch crops". Felles strategi med Norge på løsning av problemstillinger knyttet til vill atlantisk laks. 


\section{Appendix}

\subsection{Finland}

\subsubsection{Species}

The first trials of aquaculture in Finland date back to mid 1800'ies. Attempts were done with several species, even imported. The modern aquaculture started in Finland in 1960's with two main lines; market size fish production for consumers and juvenile production for enhancement of natural fish stocks. The dominating species are salmonids and coregonids (Table 1 and Table 2).

Table 1. Production of fish juveniles for releases in Finland 2010

\begin{tabular}{lr}
\hline Species & Year $\mathbf{2 0 1 0}$ \\
\hline Salmon (inc. Landlocked) <20 g & 1,111 \\
Salmon (inc. Landlocked) $20-200 \mathrm{~g}$ & 2,269 \\
Salmon (inc. Landlocked) > 200 g & 34 \\
Brown trout <50 g & 1,137 \\
Brown trout > 50 g & 1,052 \\
Sea trout <50 g & 600 \\
Sea trout > 50 g & 1,465 \\
Charr (Salvelinus spp) <50 g & 503 \\
Charr (Salvelinus spp) > 50 g & 96 \\
Whitefish (Coregonus spp) > 20 g & 23,895 \\
Whitefish (Coregonus spp) <20 g & 1,516 \\
Pikeperch & 9,156 \\
Grayling & 1,199 \\
Pike & 94 \\
Cyprinids & 1 \\
Other fish species & 34 \\
Crayfish species & 46
\end{tabular}

\subsubsection{Volumes}

The growth of Finnish aquaculture was very rapid for the first twenty years of modern farming, in 70's and 80's. Since then, after a sharp turn the production has slowly declined (Figure 1). 


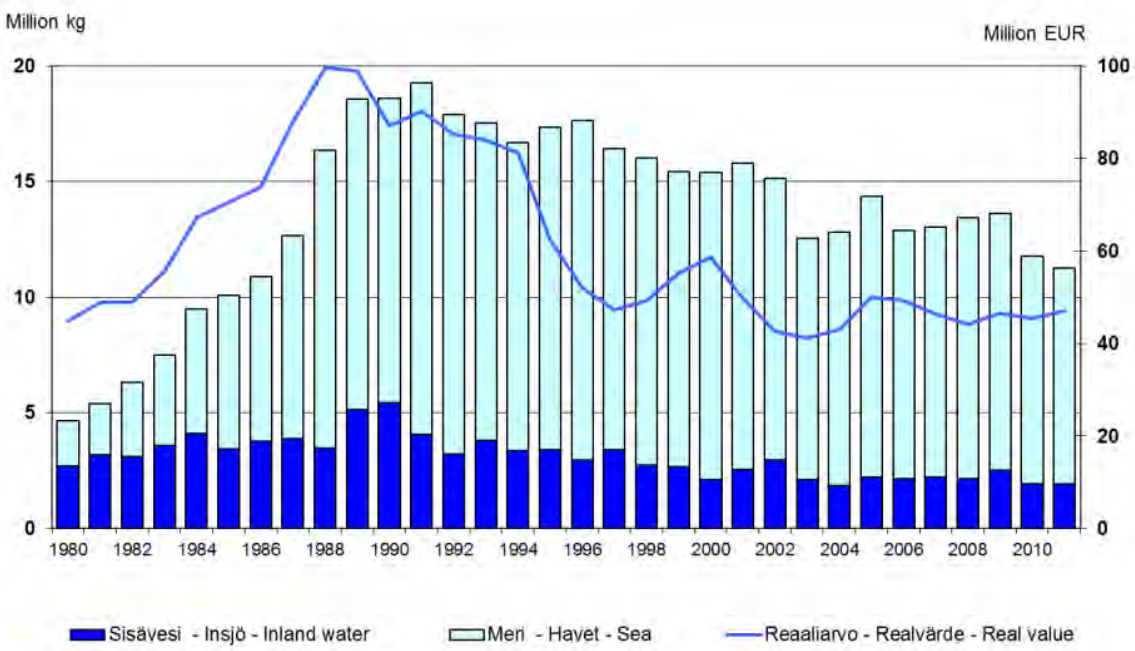

\subsubsection{Value}

The annual value (in producer's prices) of the Finnish market fish aquaculture is shown as historical trend in Figure 1 and as annual figures of 2010 in Table 2. The annual value of the production of juveniles for restocking has during the recent years been approximately 10 Million Euros (in order of magnitude). In spite of rather low absolute value figures aquaculture plays an important role in the Finnish fish industry sector. The value of aquaculture production is higher than that of commercial fishery.

\subsubsection{Industry structure}

The Finnish aquaculture has three main production technologies, each of which is used for specific products. RAS-units are emerging but still marginal production form.

- Cage farms in the Sea; market size fish for human consumption.

- Flow through farms in fresh water; seed for cage farming and salmonid smolts for restocking.

- Natural food ponds; coregonid, grayling and pikeperch fingerlings for restocking.

Products of smaller significance are crayfish, living fish for angling ponds etc. 
Table 2. Production volumes and values of market fish by main species and production areas in the Finnish aquaculture in $\mathbf{2 0 1 0}$

\begin{tabular}{lrrrr} 
& Coastal area & Inland & Total & Value \\
& $\mathbf{1 0 0 0} \mathbf{~ k g}$ & $\mathbf{1 0 0 0} \mathbf{~ k g}$ & $\mathbf{1 0 0 0} \mathbf{~ k g}$ & €M€ \\
\hline Fish & & & & \\
Rainbow trout & 9,269 & 1,715 & 10,984 & 37.6 \\
Whitefish & 577 & 146 & 723 & 5.8 \\
Trout & - & 7 & 7 & 0.1 \\
Other & - & 58 & 58 & 0.5 \\
Total & 9,846 & 1,926 & 11,772 & 44.0 \\
Roe & & & & \\
Rainbow trout and whitefish & 232 & 27 & 259 & 2.3 \\
\hline
\end{tabular}

The industry is SME-entrepreneurship in Finland. Production units are small. Some consolidation has happened on company level, the stronger ones have bought the permits of those who have given up.

Table 3. Number of aquaculture production units in Finland $\mathbf{2 0 0 6 - 2 0 1 0}$ by main production areas and technologies

\begin{tabular}{|c|c|c|c|c|c|}
\hline \multicolumn{6}{|c|}{ Aquaculture units active in different production forms } \\
\hline Year & 2006 & 2007 & 2008 & 2009 & 2010 \\
\hline \multicolumn{6}{|l|}{ Sea area } \\
\hline TOTAL & 148 & 151 & 145 & 141 & 128 \\
\hline Food production & 141 & 140 & 135 & 126 & 116 \\
\hline Juvenile production & 20 & 19 & 17 & 14 & 15 \\
\hline \multicolumn{6}{|l|}{ Inland } \\
\hline TOTAL & 350 & 350 & 363 & 374 & 357 \\
\hline Food fish production & 62 & 61 & 63 & 61 & 62 \\
\hline Juvenile production & 85 & 89 & 85 & 89 & 80 \\
\hline Natural food pond enterprs & 247 & 235 & 220 & 227 & 213 \\
\hline
\end{tabular}

The consolidation has not been possible on production unit level. Undeveloped spatial planning combined with heavy and rigid legal regulation has hindered relocation of units to fewer but bigger ones in more favorable sites.

\subsubsection{Employees}

According to the structural plan for the Finnish fisheries sector 20072013 the aquaculture sector has employed around 450-500 persons, as full time equivalents. Primary food production has a strong multiplicative effect of employment in supply industry, logistics, processing, trade etc. Including the indirect impact aquaculture employment in Finland is approximately 1,000 working years. 


\subsubsection{Geography}

The aquaculture activities cover more or less whole the Finnish territory, reflecting the availability of suitable water bodies. The map in Fig 2 shows the geographical distribution of fish culture units in Finland.

In production volumes the weight point is in S-W archipelago (incl. Aland) where the cage farming of big size fish is concentrated. Most of the natural food ponds are in Northern Finland. Flow-through farms are in central and N-E lake areas.

Figure 2. Geographical distribution of aquaculture units in Finland by farm types. Red = cage farms, lila and orange = flow-trhough farms, yellow = natural food ponds

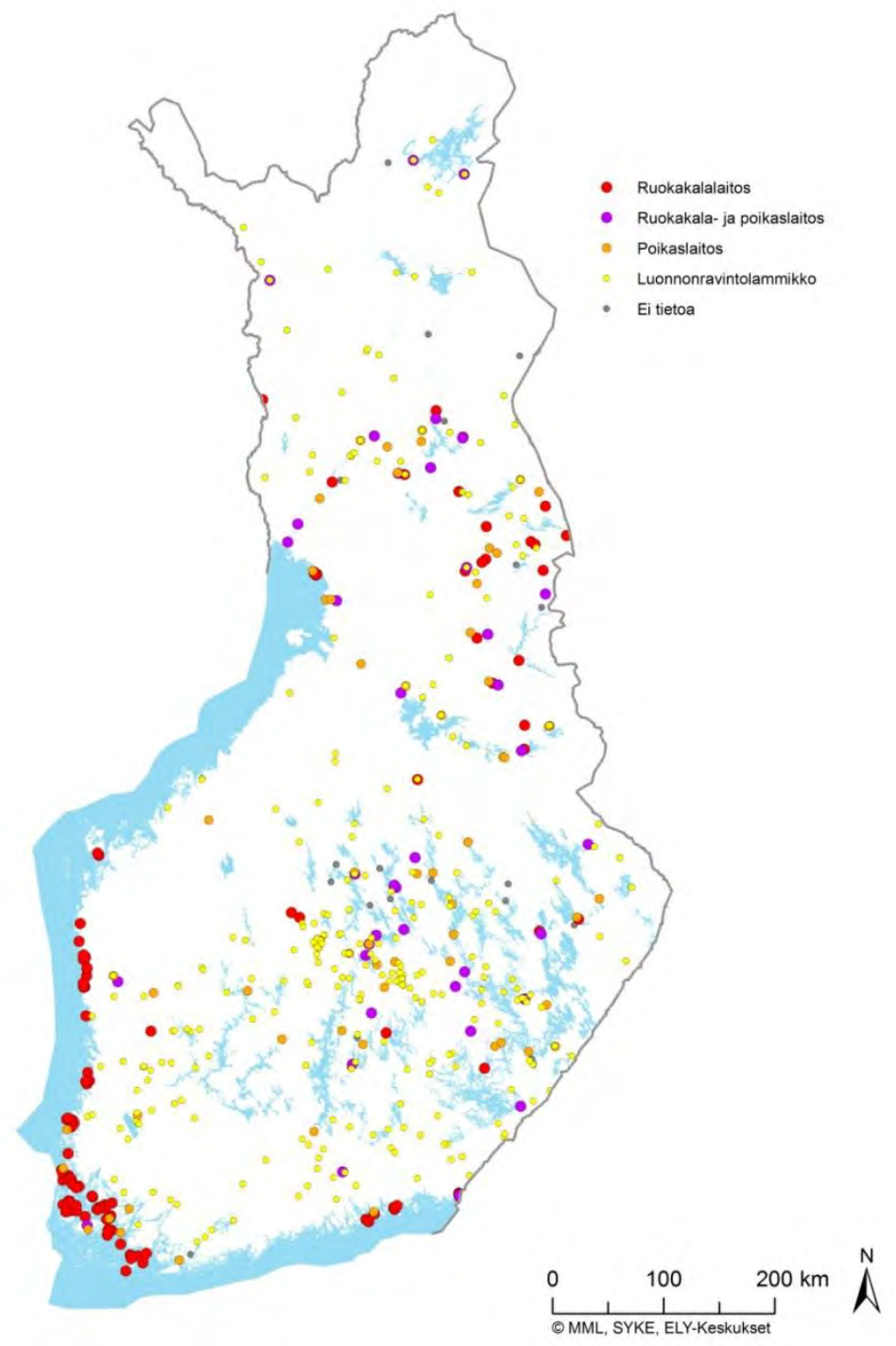




\subsubsection{Acts and regulations}

Aquaculture belongs in Finland to the scope of the general Environmental Protection Act (EPA86/2000), which requires an environmental permit for activities that pose a threat of environmental pollution. Activities subject to a permit are prescribed in more detail by the Environmental Protection Decree (EPD, 169/2000) in which also fish farming is mentioned. Fish farming exceeding certain parameters requires a permit which in a normal case is in force for about seven years. After this the permit must be renewed. Other significant regulations are Water Act (587/2011) and Water Decree (588/2011) which regulate construction in water bodies as well as use of water for processes.

\subsubsection{Challenges of sustainability}

For being sustainable in all four dimensions (economical, ecological, social and cultural) the aquaculture industry has to fulfill preconditions of long-term prosperity.

Figure 3. The big four of a prosperous aquaculture industry

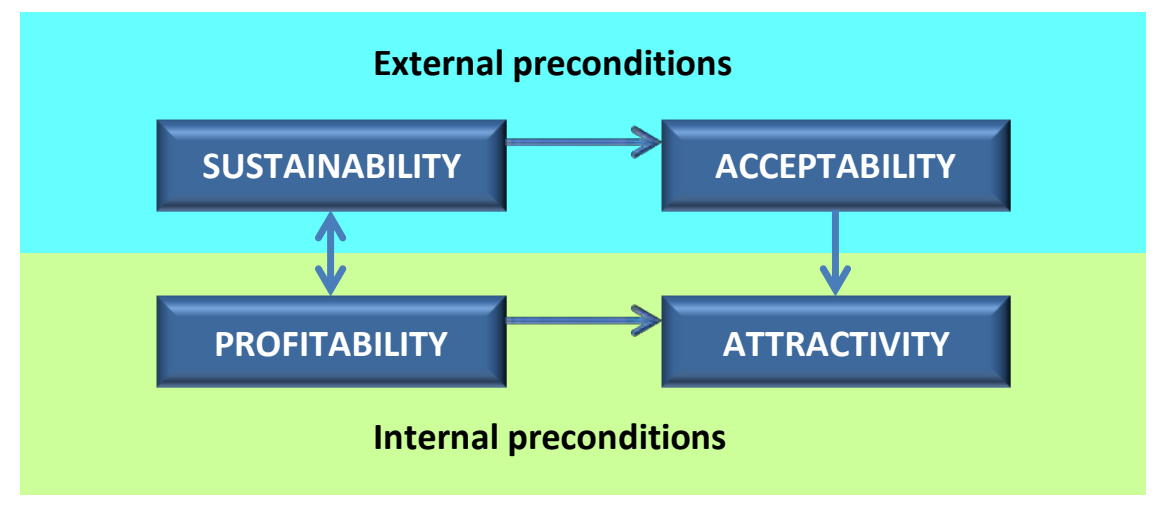

The Finnish aquaculture is not on a sustainable basis. The biggest problem is the incompatibility of environmental and economic policies and governance. Aquaculture is a minor player as nutrient loader of the Baltic Sea but due to the heavy eutrophication of the sea all licensed industries have to cut down their emissions. In aquaculture this means downsizing of production units which already are too small in terms of economic sustainability. The rigid legal regulation considers the industry as a point source loader. It doesn't support consolidation of units to more exposed and less conflict-sensitive sites. Nor does the regulation system 
support wider ecosystem approach or measures linked to that view, such as nutrient recirculation.

\subsubsection{SWOT}

The Finnish Fish Farmers' Association has for 2-3 years ago compiled the attached SWOT-analysis for the Finnish aquaculture. Most of the statements are still valid.

\begin{tabular}{|c|c|}
\hline Strengths & Weaknesses \\
\hline $\begin{array}{l}\text { domestic, local products } \\
\text { regional importance of the industry } \\
\text { good fish health situation } \\
\text { professional skills in production and R\&D } \\
\text { high valued and healthy food } \\
\text { production of roe } \\
\text { good infrastructure covering all the country } \\
\text { production for restocking }\end{array}$ & $\begin{array}{l}\text { uneven supply and quality } \\
\text { poor cooperation of farmers } \\
\text { ageing producers } \\
\text { deficiencies in business management skills } \\
\text { low profitability } \\
\text { narrow selection of products } \\
\text { small production units } \\
\text { short growing period }\end{array}$ \\
\hline Opportunities & Threats \\
\hline $\begin{array}{l}\text { market driven production in coop with processors } \\
\text { spatial planning, bigger production units } \\
\text { new species } \\
\text { new technologies } \\
\text { value added products } \\
\text { selective breeding } \\
\text { export } \\
\text { knowledge of fresh water farming } \\
\text { access to new farming sites } \\
\text { development of business structure }\end{array}$ & $\begin{array}{l}\text { environmental licensing policy } \\
\text { global market fluctuations, local reflections } \\
\text { diseases } \\
\text { protected harmful predators } \\
\text { lack of coordination of policy sectors } \\
\text { pollution, water quality problems } \\
\text { animal right extremists }\end{array}$ \\
\hline
\end{tabular}




\subsection{Norway}

\subsubsection{Species}

Norwegian aquaculture is a marine based aquaculture ${ }^{7}$ with a few hundred metric tons Arctic charr as the only freshwater specie ${ }^{8}$. Atlantic salmon farmed in sea water is by far the most dominating farmed species in Norwegian aquaculture (Table 1). The first trials with salmon started in the late 60's, but the industrial development mostly took place the latest 30. Years. Two other salmonid species are also farmed; rainbow trout in sea water and arctic charr in freshwater, with the first one being the most important. The attempt to establish other marine species in Norwegian aquaculture has so far only resulted in limited amount of marine fish and bluemussels (Table 1).

Table 1 Yearly production and value of aquaculture species (based on sale of slaughtered fish). Modified from $\mathbf{2 0 1 0}$ data from the Norwegian Fisheries Directorate

\begin{tabular}{lrr}
\hline Species & Weight (tonsround weight) & Value in 1000 NOK \\
\hline Atlantic salmon & 928,876 & $28,101,664$ \\
Rainbow trout & 54,448 & $1,668,919$ \\
Atlantic cod & 20,621 & 336,769 \\
Atlantic cod (cultured based upon wild catch) & 619 & 10,614 \\
Arctic charr & 492 & 21,523 \\
Atlantic halibut & 1,610 & 121,985 \\
Other species (Spotted wolffish and turbot) & 23,598 & 509,378 \\
Shell and shellfish (gross sale) & 2,001 & 18,744 \\
Total & $1,006,010$ & $30,286,372$ \\
\hline
\end{tabular}

\subsubsection{Volumes}

The total growth in aquaculture in Norway over the last 40years is presented in Figure 3. We see the dominating effect of Atlantic salmon took off from the beginning of the 80 's and developed strongly over the next 20 years. Marine fish aquaculture started in the beginning of 90's but after 20 years still only contributes with a small part of the total volume.

\footnotetext{
${ }^{7}$ The production of salmonid smolts are freshwater based

${ }^{8}$ In fact the larges production of Arctic charr is partly marine in sea cages in part of the production cyclus.
} 
Figure 3. Development of Norwegian production of fish in aquaculture 1971-2009 (all species Mtons). Modificated from Gullestad et al. 2011

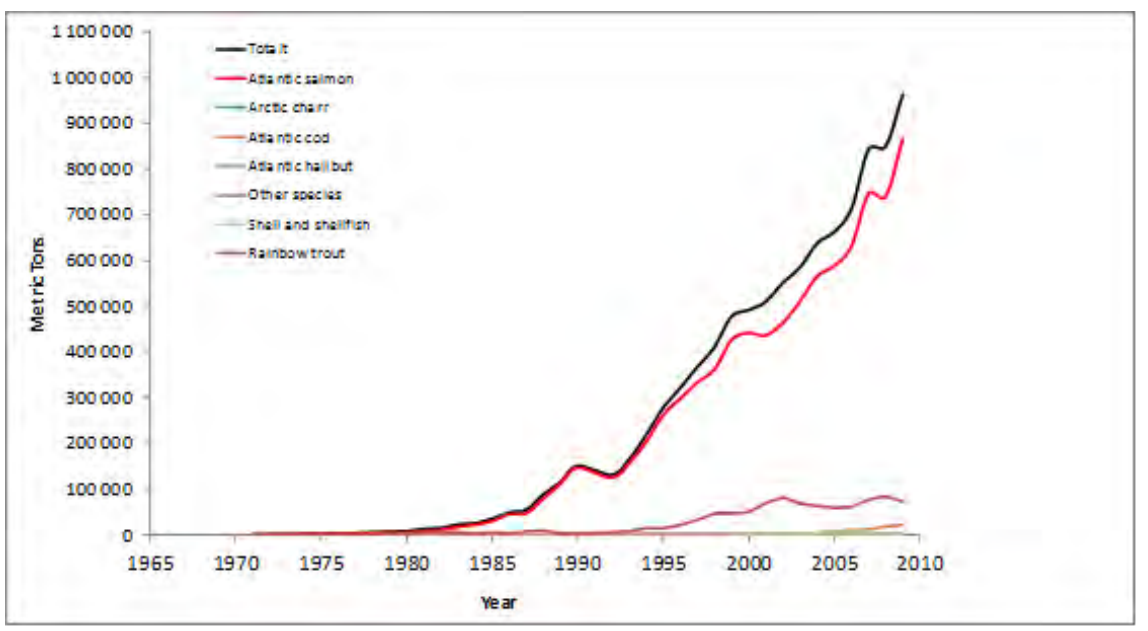

\subsubsection{Value}

Annual production (metric tons) and value (1,000 NOK) for the period 1994-2010. The total value of around 30 billion NOK in 2010 brings aquaculture up the third larges export industry in Norway.

Figure 5 Development (1994-2010) in value (MNOK blue line) and productioninin in Mtons (yellow bars) of fish and shellfish in Norwegian aquaculture. Figure is based on data from the Norwegian Fisheries Directorate

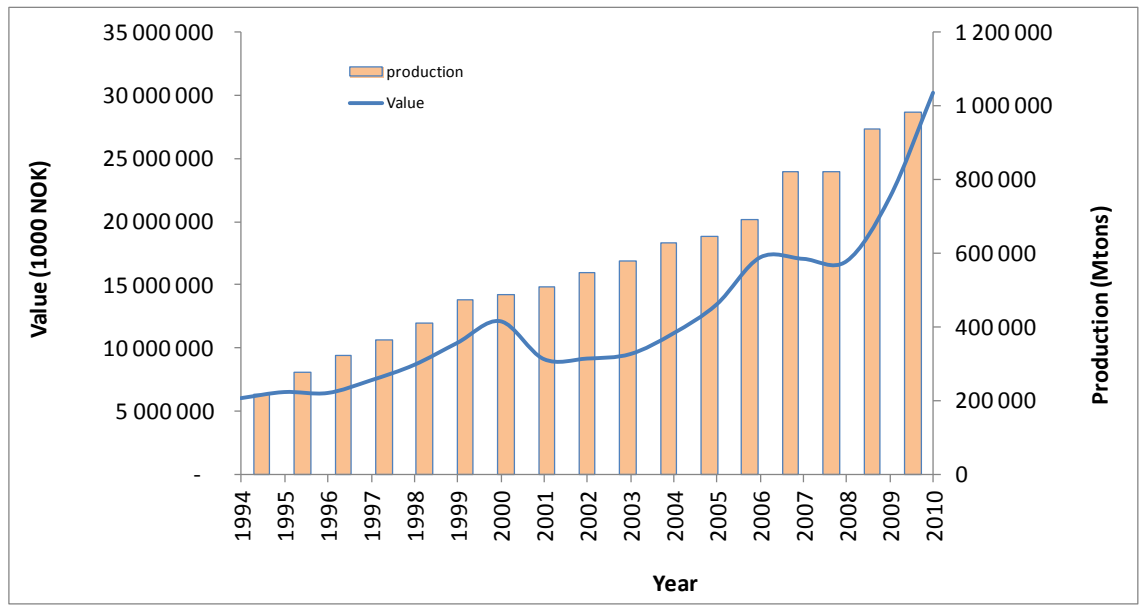




\subsubsection{Industry structure}

The Norwegian aquaculture has three main production technologies, each which is used for a specific life stage in the production.

- Broodstock farms with egg production, using both net based cage farms and land based with type 2 or type 3 (se below) technology

- Flow-through tank based farms in freshwater, used mainly for production juvenile fish for on-growing farming in sea cages

- RAS tank based farms in freshwater, used mainly for production juvenile fish for on-growing farming in sea cages.

- Floating flexible (PE or steel) net based cage systems in the sea for on-growing to market size.

- The harvest and slaughtering of fish is done by coastal based large harvesting plants.

Transport of live fish from (1) to (2 and 3) is mostly by car and by well boats from (2 and 3) to (4). Life fish transport from (4) to (5) is also done by well boats.

There are around 250 operating licenses for the production of juvenile salmon and rainbow trout in Norway and around 27 licenses for juvenile production of other species (Table 2). A boost in building of farms for the production of smolts and fry of salmon and rainbow trout happened in mid 80'thies. Currently there is a high building rate of recirculation systems for aquaculture (RAS) of fry and smolt of salmonid fish. The RAS technology applied is provided from a combination of Danish and Norwegian suppliers.

There are about 169 companies operating in the salmon and rainbow trout production. There is a mixture of small, medium sized and large companies. The overall trend is merger and acquisition. Vertical integration to various extends. In marine fish production the licenses for both juvenile and on-growing produ ction (513) are operated by 27 companies in juvenile production and 81 companies in on-growing production. The commercial interest in farming marine fish is currently limited and not reflected by the number of licences. There are nearly five times more growing out licenses in the sea for salmon and rainbowtrout trout than for marine fish, and opposite marine fish, they are all used. Licenses for shell and shellfish are the fewest. (Table 3). 
Table 2 An overview of licenses for aquaculture production of juvenile fish in Norway. Based on data from Norwegian Fisheries directorate

\begin{tabular}{lr}
\hline Licences - juvenile production & Numbers \\
\hline Salmon and rainbow trout & 249 \\
Other species, juvenile companies & 27
\end{tabular}

Table 3 An overview of number of licenses and number of sites at sea for aquaculture production of adult fish in Norway. Based on data from the Norwegian Fisheries directorate

\begin{tabular}{lr}
\hline Grow out licences, etc, & Numbers \\
\hline Grow out-, brood stock- and R\&D licences salmon and rainbowtrout & 1,064 \\
Licenses other fish species & 513 \\
Licenses shell and shellfish & 377 \\
On growing sites at sea for salmon and rainbow trout & 1,023 \\
On growing sites at sea for other species & 218
\end{tabular}

The aquaculture production is spread along ten of Norway's counties. Figure 5 show in which counties the production intensity based on total working hours, is the highest. The most labour intensive areas are Nordland (20\%), Hordaland (18\%) and Trøndelag (south and north) (16\%). In terms of slaughtered fish (salmon and trout) the largest counties are Nordaland and Hordaland (Figure 6)

Figure 5 Total number of working hours in aquaculture production in Norway, distributed on the 10 most active counties. Based on data from Norwegian Fisheries Directorate

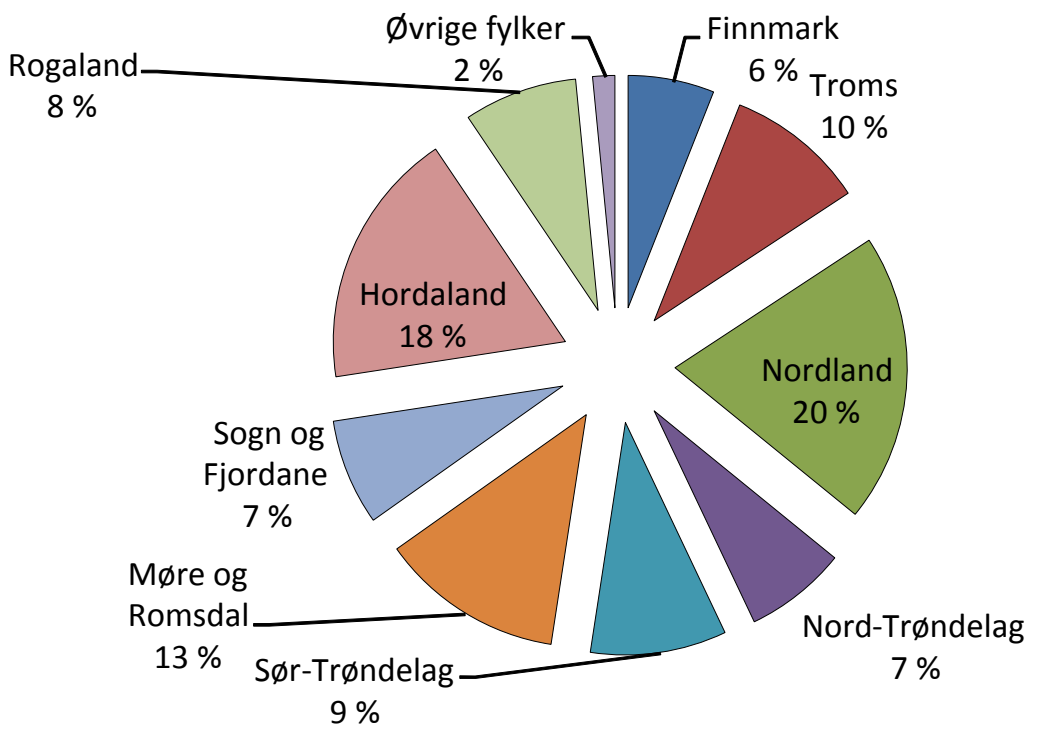


Figure 6 The amounts of slaughtered fish (salmon and rainbow trout) (blue stacks) and smolts (red line) in each county in Norway. The smolt production in Finnmark is included in the Troms data..The figure does not necessary reflect the production in each county since fish are transported live across counties from on-growing sites to harvesting plants to be slaughtered. Based on data from Norwegian Fisheries Directorate

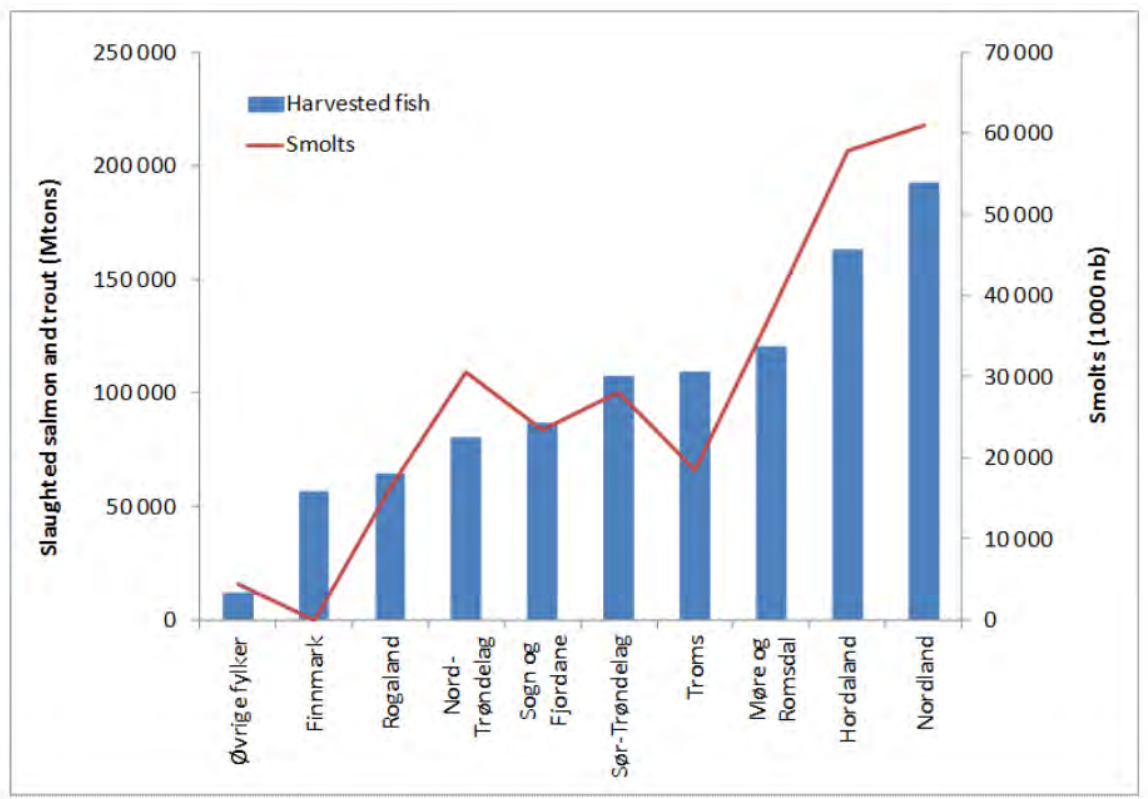

\subsubsection{Employees}

Statistics from the Norwegian Fisheries Directorate show that in 2010 there were 5,500 persons employed in the aquaculture sector, as full time equivalents. Around 4,900 of these worked with salmon and trout production, and around 600 worked in the production of other species. Table 4 show that around 1,500 persons worked in the salmon and trout juvenile (smolt) production, and around 3,500 in the on-growing production. The industry is dominated by male employees, only about 900 of the total employees in 2010 were women. The yearly changes (in \%) of employees does not seem not to be directly correlated to yearly changes in production (in \%) (Figure 7). It can be observed that the high growth in production in the period 1994-1998 was not followed up by an increase in the number of employees until a few years later (1996-1998). 
Table 4 Employees in aquaculture industry in Norway 2010. Based upon data from Statistisk sentrakbyrå, Norway

\begin{tabular}{lr}
\hline Employees & Number of employees \\
\hline In aquaculture production & 5,528 \\
Salmon and trout, juvenile production & 1,476 \\
Salmon and trout, on-growing production & 3,454 \\
Other species & 598
\end{tabular}

Figure 7 The covariance between changes (\% year-1) in Norwegian aquaculture production and employees over a time span of 16 years (1994 - 2009), The figure is based upon data from official statistics in Norway (Norwegian Directorate for Fisheries)

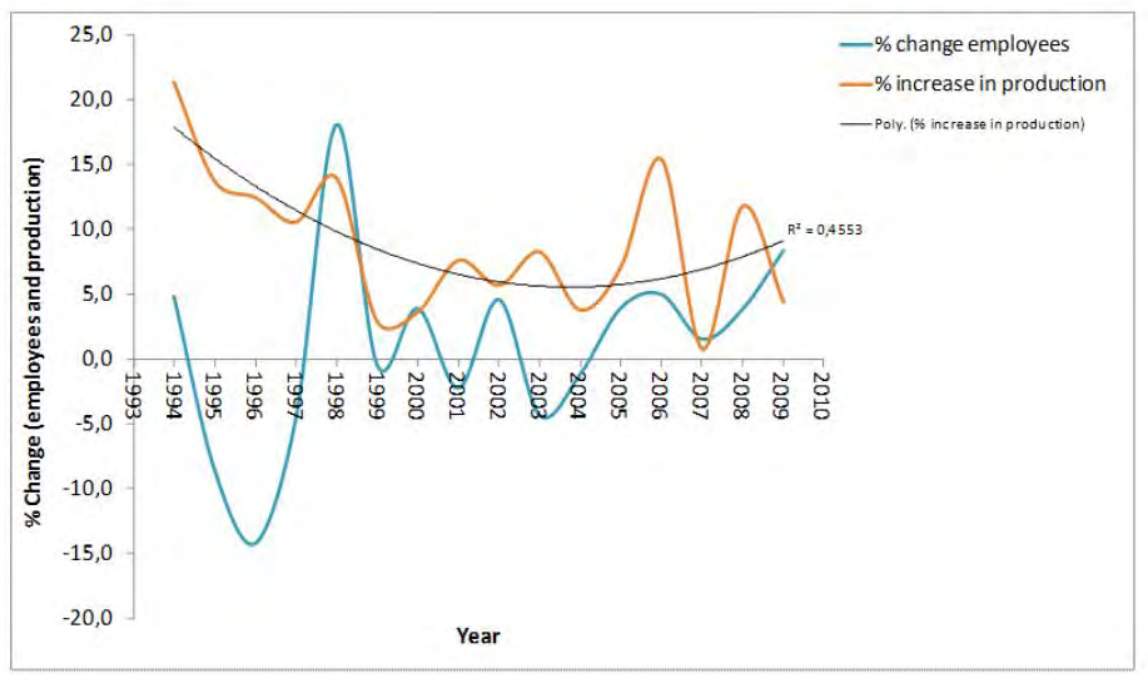

\subsubsection{Geography}

The aquaculture activity in Norway is shown in Figure 8. The figure includes all types of licenses for fish, crustaceans, shell and shellfish and clearly shows the coastal marine concentration. Inland marks include licenses for juvenile production for on-growing production in sea cages, arctic charr, and cultivation farms. 


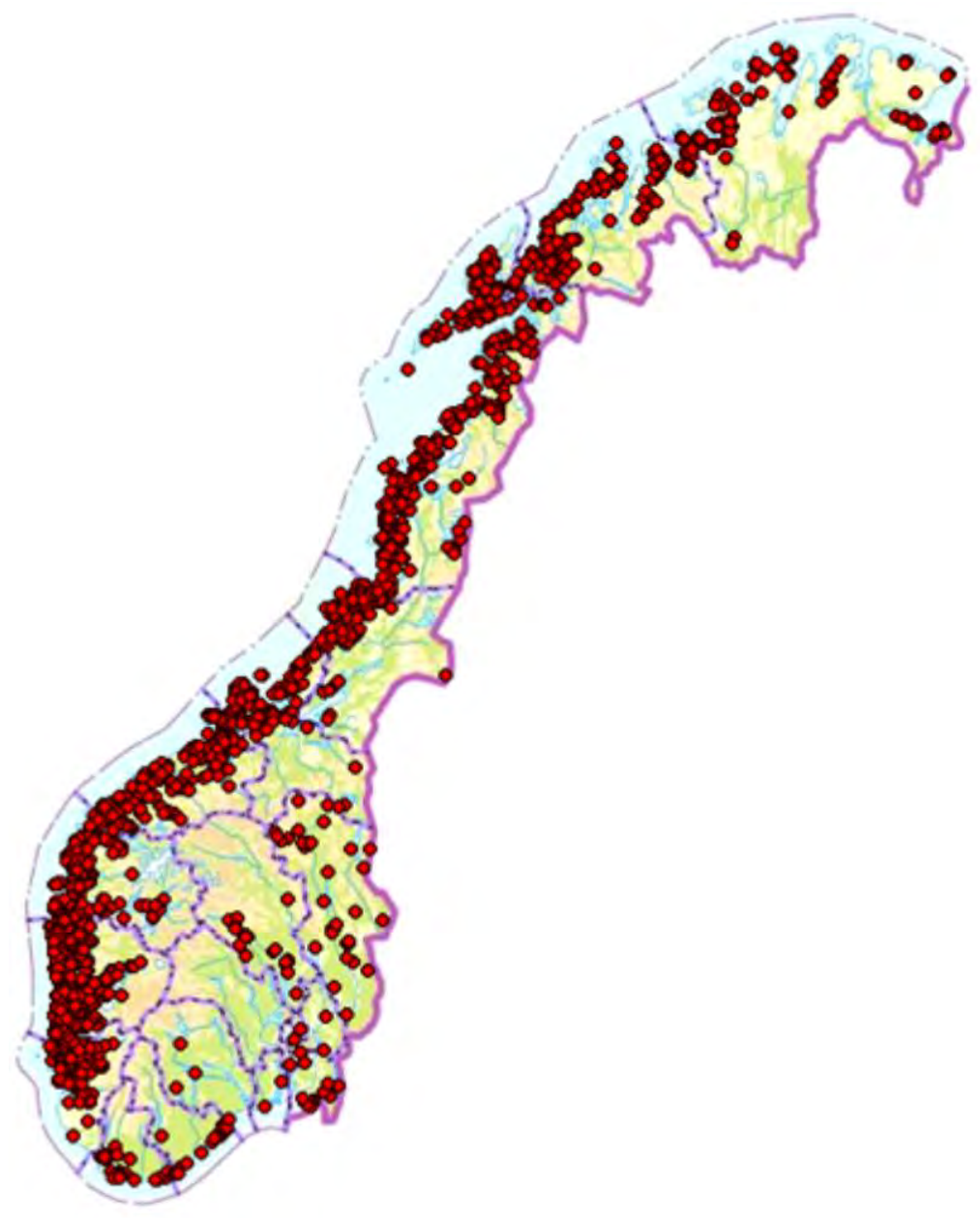

Source Fiskeridirektoratet

\subsubsection{Acts and regulations}

The establishment of aquaculture is regulated by several Acts with associated regulations. A recent review of the juridical framework for aquaculture in Norway is given by Gullestad et al., 2011. A brief overview based on this, is given below;

Act of 17 June 2005 no. 79 relating to aquaculture (the Aquaculture Act), administered by the Directorate of Fisheries. The purpose ( $\S 1$ ) of this Act is to promote the profitability and competitiveness of the aquaculture industry within the framework of a sustainable development and contribute to the creation of value on the coast. This Act warrants the requirement for a license to conduct aquaculture, number of licenses 
and maximum biomass. Pursuant to this Act there is established a system where a license to conduct aquaculture can not be given before all the different sector authorities have given the necessary permissions according to the Acts they administer. Application for an aquaculture license is initially considered by the county authority. Regulation about how to operate an aquaculture site is given by FOR 2008-06-17 nr 822 and maximum biomass for one license is 780 Mtons in sea cage farming and 325 Mtons in freshwater. The number of juvenile fish (smolt) is limited to 2.5 million pr bio secure unit.

Act of 19 December 2003 no. 124 (the Food Act), administered by the Norwegian Food and Safety Authority. This Act warrants actions directed towards prevention and fight against diseases and parasites inside the aquaculture unit and wild organism close to the farm. The Act with appurtenant Regulations instruct aqua culturists to fulfill all demands at any time and prove this through a self-contained system, which is inspected and controlled by the Norwegian Food and Safety Authority. Pursuant to this Act, regulations that have implication for establishment, production and zones can be implied.

Act of 19 June 2009 no. 97 (The Animal Welfare Act), administered by the Norwegian Food and Safety Authority. This Act warrants requirements for establishing and operating aquaculture production in compilation with animal welfare considerations. Pursuant to this Act are conditions associated with water quality, design and operations of aquaculture farms.

Act of 13 Mars 2003 no. 6 (The Pollution Control Act), administered by the Climate and Pollution Agency. This Act warrants protection against pollution and waste and is delegated to the County governor office when it comes to discharge from aquaculture. The local County governors 'office needs to give discharge permission according to the Pollution Control Act before permission according to the Aquaculture Act can be given. A system with environmental investigations (MOM) is established to document if the aquaculture operation is compiling with the Act and appurtenant Regulations. The EU Water frame Directive is being implemented in Norway under the coordination of the Norwegian Directorate for Nature Management, and the work with mapping and categorizing of water bodies are under progress. The mapping will identify the areas not suitable for aquaculture.

Act of 17 April 2009 no. 19 (The Harbour Act), administered by the Norwegian Coastal Administration. This Act warrants use of sea area for transport and navigation. An aquaculture licence must not be in conflict with these interest. 
Act of 27 June 2008 no. 71 (The Planning and Building Act), administered by The Ministry of the Environment. This Act is a procedural code for establishing aquaculture. To obtain an aquaculture license it is a condition that the site(s) are planned to be within areas purposed for aquaculture by the local government.

Act of 24 November 2000 no. 82, (The Water Resources Act), administered by the Norwegian Water Resources and Energy Directorate. This Act warrants the use of surface and groundwater. For aquaculture it comes to play when applying for the use of freshwater for smoltproduction and inland fish farming.

Act of 19 June 2009 no. 100 (The Nature Diversity Act), administered by The Ministry of Environment. The Act warrants many principals within environmental law which have to be applied by the assigning government when considering licenses for aquaculture. The application of the principle of ecosystem based management comes into play when considering the effect of a aquaculture site. Pursuant to this Act say that governmental decisions affecting the biodiversity should be built upon scientific documentation about the population of the species, spread of nature types, ecological status and the effects of the influence. A precautionary principle should be applied where there is lacking scientific data about the potential effects.

Act of 15 May 1992 no. 47 (The Act relating to Salmonids and FreshWater Fish etc.), administrated by The Ministry of Environment, the Norwegian Directorate for Nature Management, The County Governor, The county authority and local municipal authority. The Act warrants the protection of natural wild populations of anadromous salmonids and their habitat. The regulation with national salmon fjords and national salmon rivers were after a joint resolution in the Norwegian national assembly and is deeply rooted in the The Act relating to Salmonids and Fresh-Water Fish with pursuant regulations following several Acts (see St.prp nr 32 (2006-2007). Until the The Nature Diversity Act, chapter IV about invasive species comes into act, the import of live anadromous salmonides is regulated by the Act relating to Salmonids and Fresh-Water Fish.

\subsubsection{Challenges of sustainability}

Sustainability (or green growth) is becoming increasingly important as a prerequisite for future development of the Norwegian aquaculture industry. The term may include a variety of items, but we draw attention to the government's five sustainability elements (see Table 4), where we 
see that the important issues are escapes, sea lice, pollution, land use and feed resources.

Table 4 The five focus elements for a sustainable development of the aquaculture sector set by Norwegian Government

\begin{tabular}{|c|c|c|}
\hline NR & ELEMENT & Goal \\
\hline 1 & Genetic influence and escapees & $\begin{array}{l}\text { Aquaculture does not cause irreversible genetic changes of the wild } \\
\text { fish populations }\end{array}$ \\
\hline 2 & Pollution and discharge & $\begin{array}{l}\text { All aquaculture sites in use keep within an acceptable environmental } \\
\text { condition and does not have a higher discharge of nutrients or } \\
\text { organic material than the resipient can handle. }\end{array}$ \\
\hline 3 & Disease and parasites & $\begin{array}{l}\text { Diseases in aquaculture does not have a population effect on wild } \\
\text { fish, and as fish much as possible are produced to harvestable size } \\
\text { without the use of therapeutics. }\end{array}$ \\
\hline 4 & Use of area & $\begin{array}{l}\text { The aquaculture industry has a layout of sites and area use that } \\
\text { minimize the environmental effects and exposure hazards. }\end{array}$ \\
\hline 5 & Feed resources & $\begin{array}{l}\text { The need for feed ingredients / resources are covered with out over } \\
\text { exploiting the wild marine fish stocks }\end{array}$ \\
\hline
\end{tabular}

\subsubsection{SWOT}

\begin{tabular}{|c|c|}
\hline Strength & Weaknesses \\
\hline $\begin{array}{l}\text { salmon farming established as a viable business, } \\
\text { cost leader position } \\
\text { stable and competitive business climate } \\
\text { efficient law and regulations } \\
\text { suitable natural coastline and water for netbased } \\
\text { cage culture of salmoinids } \\
\text { leading in technology for net based cage culture } \\
\text { automatization } \\
\text { large scale effect } \\
\text { good fish health and biosecurity } \\
\text { knowledge and education }\end{array}$ & $\begin{array}{l}\text { salmon depended business } \\
\text { tropic level of salmon } \\
\text { conceited position as production leader with current } \\
\text { technology and specie }\end{array}$ \\
\hline Opportunitie & Threats \\
\hline $\begin{array}{l}\text { new technology for removing risk and effects of } \\
\text { escaped fish } \\
\text { micro-organisms as amino acid } \\
\text { more competitive to produce fish than other } \\
\text { species } \\
\text { utilize nutrient discharge } \\
\text { utilize organic waste discharge } \\
\text { utilize offshore (oil and gas) knowledge for industry } \\
\text { building }\end{array}$ & $\begin{array}{l}\text { unsolved conflict with wild salmon interest (escapees } \\
\text { and salmon lice) } \\
\text { public reputation } \\
\text { cost of increased sustainability difficult to implement on } \\
\text { a generic commodity product with out competitive } \\
\text { considerations } \\
\text { high cost economy }\end{array}$ \\
\hline
\end{tabular}




\subsection{Sweden}

\subsubsection{Volumes in tonnes and value}

There was a rapid increase in rainbow trout production in the beginning of 1980's, but the production peaked by the end of the decade (figure 1). The drop in production was mainly associated with an increased competition on the market and too high production costs. Many companies went bankrupt. The Arctic charr farming started in the 80's at a very small scale. It was not before the end of the 1990's that the production started to expand (Figure 1). We expect a rapid increase of the Arctic charr production the coming 10 years, with a prognosis of 5-6,000 metric tons annually. The production of blue mussels varies dramatically between years, mainly because of periodic stops in the harvest due to toxic algae blooms.

Figure 1. The development of Swedish aquaculture over the last 40 years (metric tons)

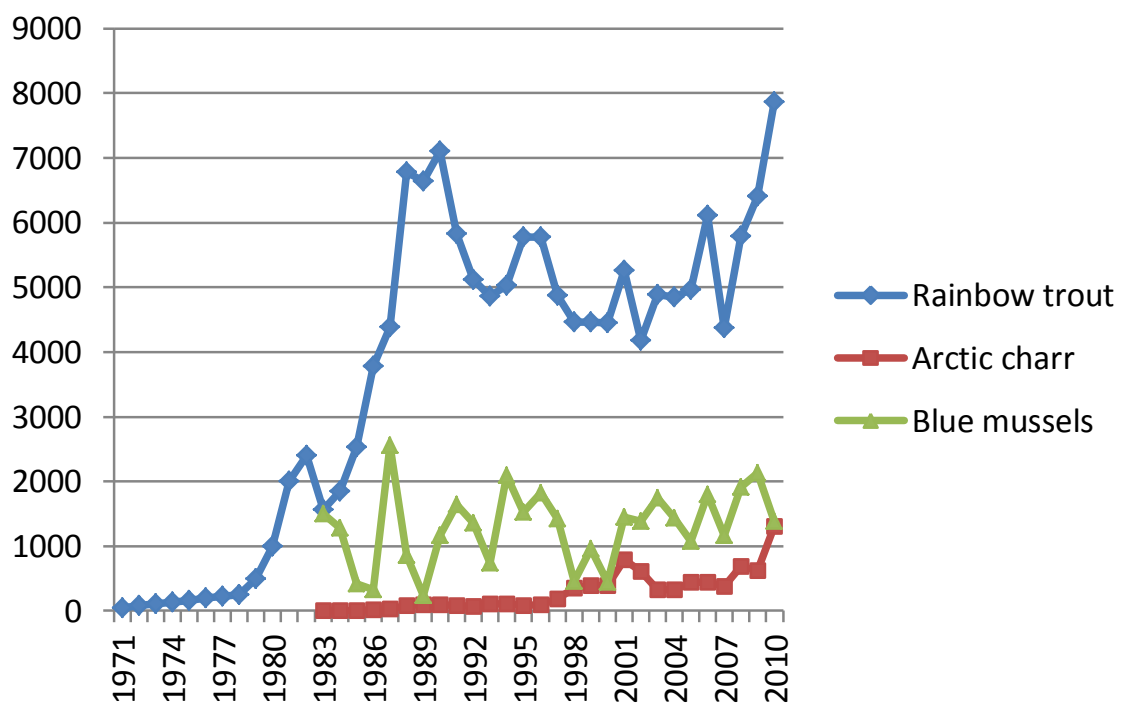

The total production of farmed fish for consumption was in 20107,851 tonnes slaughtered weight, which corresponds to 9,260 tonnes round weight (Table 1). This is an increase of $28 \%$ compared to the production in 2009. The dominating species in Sweden is rainbow trout, accounting for $85 \%$ of the total production or 7,859 tonnes in 2010 . The Arctic charr production was 1,307 tonnes in 2010 . The production of blue mussels 
varies dramatically between years, mainly because of periodic stops in the harvest due to toxic algae blooms.

The total value of farmed fish in 2010 was 253.7 million SEK, which is an increase of $20 \%$ compared with the year 2009 (Table 1). Rainbow trout stands for $74 \%$ of the value.

Table 1 Yearly production and value of aquaculture species in $\mathbf{2 0 1 0}$ (based on sale of slaughtered fish). Data from Statistics Sweden (SCB)

\begin{tabular}{lrr}
\hline Species & Weight in metric tonne round weight & Value in million SEK \\
\hline Rainbow trout, fresh water & 5,576 & 188,9 \\
Rainbow trout, sea & 2,283 & \\
Arctic charr & 1,307 & 50,1 \\
Eel & $172 *$ & $13,2 *$ \\
Perch & 0.5 & - \\
Cray fish & 1 & - \\
Blue mussels & 1,382 & 6,7 \\
\hline
\end{tabular}

*values from 2008

\subsubsection{Industry description (structural, value chain)}

The most common production system for on-growing of farmed fish in Sweden is floating net cages. The average size of cages is $932 \mathrm{~m}^{3}$. There have been several larger structural changes in Swedish fish farming the last 10-15 years. Fish farms have moved and expanded in fresh water at the expense of coastal sea areas. The main reason for this is environmental legislation and environmental situation in the Baltic Sea. The total number of licenses for juvenile production is 152 of which rainbow trout and Arctic charr dominates (table 2). The production of Atlantic salmon and brown trout juveniles is exclusively for stocking purposes.

Table 2 An overview of licenses for aquaculture production of juvenile fish in Sweden. Data from Statistics Sweden (SCB)

\begin{tabular}{lr}
\hline Licenses - juvenile production & Numbers \\
\hline Rainbow trout & 55 \\
Arctic charr & 20 \\
Brown trout & 47 \\
Atlantic salmon & 8 \\
Eel & 1 \\
Cray fish & 8 \\
Oyster & 1 \\
Other & 12 \\
\hline
\end{tabular}

There is at current 138 licenses for grow-out production of fish, crayfish and mussels in Sweden (Table 3). Rainbow trout is the dominating species in terms of licenses. There are, however, only 12 licenses with a production of more than 100 ton annually. The production of these 
companies stands for $90 \%$ of the total rainbow trout production. Most rainbow trout farms are very small, with a production lower than 50 tons per year.

Economic indicators show large differences between different companies, where the six largest stands for more than half of the turnover. The development during the last decade has continued with an increased concentration of fewer and larger companies. A significant part of on growing farms producing rainbow trout have been taken over by foreign companies, mainly from Finland. In fact, a large part of the Swedish rainbow trout production is transported directly to Finland and sold on the Finnish domestic market. There is also a growing interest from foreign companies in the Swedish Arctic charr production. Norwegian companies have already started or are interested in starting farms in northern Sweden.

Table 3 An overview of number of licenses and number sites in sea for aquaculture production of adult fish and mussels in Sweden. Data from Statistics Sweden (SCB)

\begin{tabular}{ll}
\hline Grow-out licenses & Numbers \\
\hline Rainbow trout & 80 \\
Arctic charr & 15 \\
Eel & 1 \\
Cray fish & 30 \\
Blue mussels & 12 \\
\hline
\end{tabular}

\subsubsection{Employees}

The total number of employees in the Swedish aquaculture sector is estimated to 400 on yearly basis (Table 4). Of that total number about $89 \%$ is men and $11 \%$ women. There is roughly equal numbers of employees between juvenile and on-growing production.

Table 4. Employees in the aquaculture industry in Sweden 2010. Data from Statistics Sweden (SCB)

\begin{tabular}{ll}
\hline Employees & Number \\
\hline Total number of employees & 399 \\
Juvenile production & 182 \\
On-growing production & 217 \\
\hline
\end{tabular}




\subsubsection{Geography}

The localisation of fish-farm companies are well spread over the country.

Figure 2. A schematic view of the localisation of Swedish fish farms. Please note that the locations are not the actual sites for production

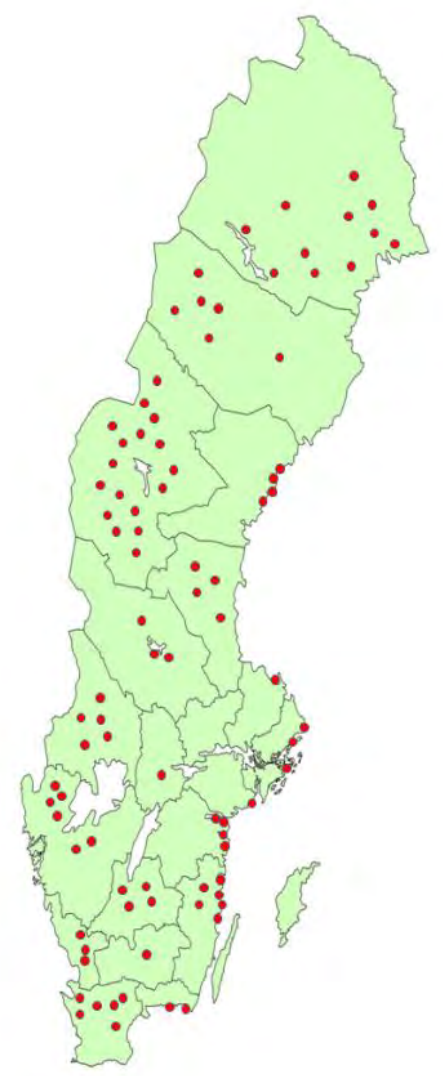

\subsubsection{Acts and regulations}

In order to farm fish or other aquaculture species, a permit is needed. The permit is applied for at the County Administrative Board. Sweden is divided into twenty-one counties. The County Administrative Board is a coordinating national authority with supervisory responsibilities. A fish farming permit in Sweden consists of two parts: 


\section{Permit for holding fish}

Regulations:

- Regulation of fishing, aquaculture and fisheries (SFS 1994:1716)

- the Board of Agriculture regulation on fish farming and transport of fish between fish farms, slaughter of farmed fish, and marking of aquaculture facilities (SJVFS 2011:34).

\section{Permit for environmentally dangerous activities}

Regulations:

- the Swedish Environmental Protection Agency (EPA) environmental code

\section{Permit for holding fish}

The movement of fish between farms and stocking of fish is regulated by the Board of Agriculture regulation on fish farming and transport of fish between fish farms, slaughter of farmed fish, and marking of aquaculture facilities. The permit shall state:

- The location of the farm

- What species (or local strains) that are farmed

- Purpose of the farming (food, stocking, or other)

- Farming techniques and methods

- Specific conditions for health control

For each growing season, this information must be updated and sent to the County Administrative Board.

\section{Permit for environmentally dangerous activities}

The environmental effects of fish farming is regulated by the Swedish Environmental Protection Agency (EPA) via the environmental code, which from the 1 January 1999 replaced fifteen previous environmental acts that were amalgamated into the Code. The Environmental Code shall be applied in such a way as to ensure that:

1. human health and the environment are protected against damage and detriment, whether caused by pollutants or other impacts;

2. valuable natural and cultural environments are protected and preserved; 
3. biological diversity is preserved;

4. the use of land, water and the physical environment in general is such as to secure a long term good management in ecological, social, cultural and economic terms; and

5. re-use and recycling, as well as other management of materials, raw materials and energy are encouraged with a view to establishing and maintaining natural cycles.

The main concerns of fish farming in relation to the code are the release of nutrients (phosphorus and nitrogen) and other pollutants, and disturbances in terms of noise and landscape impact.

When applying for a fish farming permit, an environmental impact statement must be submitted together with the application. The purpose of an environmental impact assessment is to establish and describe the direct and indirect impact of a planned activity or measure on people, animals, plants, land, water, air, the climate, the landscape and the cultural environment, on the management of land, water and the physical environment in general, and on other management of materials, raw materials and energy. Another purpose is to enable an overall assessment to be made of this impact on human health and the environment.

\section{Other regulations once a permit is approved}

1. the Swedish animal welfare agency regulation on farming of fish (DFS 2006:8)

2. the Board of Agriculture regulation on obligatory health control of farmed fish (SJVFS 2006:15)

3. the Board of Agriculture regulation on animal health demands for animals and products from aquaculture, and about prevention of some diseases in aquatic animals (SJVFS 2009:42)

4. the Swedish Agency for Marine and Water Management regulation on the release of fish and movement of fish in other cases than between farms (FIFS 2011:13)

5. the Board of Agriculture regulation on the control of certain diseases affecting bivalve molluscs (SJVFS 1998:98)

6. the Board of Agriculture regulation on importation of fish, crustaceans and molluscs and products thereof (SJVFS 2000:157) 
7. the Board of Agriculture regulation on the export of aquaculture animals to countries within the European Union (EU) and to Island and Norway (SJVFS 2000:84)

8. Council Regulation (EC) No 708/2007 of 11 June 2007 concerning use of alien and locally absent species in aquaculture

9. Regulation of processing facilities for aquaculture animals (SFS 2009:251)

10.Some of the regulations listed above are going to be re-written or updated during 2012-2013. The reasons for this are to make the regulations fewer, easier to understand and use as well as better adapted to the current legislations from the EU.

\subsubsection{Challenges of sustainability}

The largest concerns of aquaculture in Sweden have been the environmental effects and especially the eutrophication effects of fish farming (table 5). The main reason for this is lack of knowledge and instructions on how to handle the environmental effects. There are large fresh water resources suitable for production in Sweden and modified waters like hydroelectric power dams have been highlighted as prioritized for fish farming.

\begin{tabular}{|c|c|}
\hline Strength & Opportunities \\
\hline $\begin{array}{l}\text { Huge fresh water resources } \\
\text { Many modified waters with reduced ecological } \\
\text { value (hydroelectric power dams) } \\
\text { Good potential for sea farming in the Gulf of } \\
\text { Bothnia }\end{array}$ & $\begin{array}{l}\text { Create jobs in rural areas } \\
\text { Locally produced food } \\
\text { Synergetic effects with sports fishing } \\
\text { Ecosystem services in hydroelectric power dams }\end{array}$ \\
\hline Weaknesses & Threats \\
\hline $\begin{array}{l}\text { Poor knowledge base within the whole chain } \\
\text { from farmers to politicians } \\
\text { Lack of education (practical training and universi- } \\
\text { ty level) } \\
\text { Lack of investors and financing }\end{array}$ & $\begin{array}{l}\text { Competition (mainly from Nordic countries) } \\
\text { Access to water (ownership) } \\
\text { Public resistance } \\
\text { Environmental degradation (eutrophication, diseases } \\
\text { and spread of unwanted genes) }\end{array}$ \\
\hline
\end{tabular}




\subsection{Denmark}

\subsubsection{Species}

The Danish aquaculture industry has for more than one hundred years concentrated on production of rainbow trout in freshwater ponds. I the last decades this production has diversified into other productions based on rainbow trout (large seawater produced fish, roe production, golden trout, recirculation systems) and production of a number of new species.

Table 1: Production in metric tons in Danish aquaculture 2003-2010

\begin{tabular}{|c|c|c|c|c|c|c|c|c|}
\hline Species & 2003 & 2004 & 2005 & 2006 & 2007 & 2008 & 2009 & 2010 \\
\hline Perch & 0 & 0 & 0 & - & 0 & 0 & 1 & 1 \\
\hline Barramundi & - & - & - & - & 2 & 0 & - & - \\
\hline Blue mussel & 11 & 55 & 280 & 411 & 954 & 1,737 & 2,643 & 756 \\
\hline Arctic charr/Brook trout cross & - & 182 & 105 & 199 & 208 & 207 & 160 & 160 \\
\hline Brown trout & 97 & 106 & 68 & 78 & 103 & 98 & 63 & 56 \\
\hline Arctic charr & - & 1 & - & - & - & - & - & - \\
\hline Pike & 1 & 0 & 0 & 0 & 0 & 0 & 0 & 0 \\
\hline Sea bream & - & - & - & - & - & 0 & - & - \\
\hline Golden trout & - & - & 7 & 10 & 22 & 26 & - & - \\
\hline Sea trout & 79 & 76 & 78 & 87 & 81 & 75 & 75 & 78 \\
\hline Whitefish (Coregonus) & 0 & 0 & 1 & 0 & 3 & 0 & 0 & 3 \\
\hline Carp & 0 & 0 & 0 & 0 & 0 & 0 & 0 & - \\
\hline Brook trout & 247 & 190 & 206 & 174 & 270 & 184 & 213 & 115 \\
\hline Koi & - & - & - & - & 0 & - & - & - \\
\hline Crayfish & 0 & 0 & 0 & 0 & 0 & 0 & 0 & - \\
\hline Salmon & 16 & 16 & 18 & 18 & 16 & 12 & 15 & 17 \\
\hline Catfish & - & 1 & - & - & - & - & - & - \\
\hline Turbot & 5 & 6 & 7 & 8 & 38 & 6 & 4 & 6 \\
\hline Rainbowtrout & 35,287 & 40,454 & 37,058 & 34,903 & 39,058 & 38,500 & 36,906 & 36,509 \\
\hline Pike-perch & 6 & 10 & 49 & 36 & 47 & 55 & 106 & 60 \\
\hline Flounder & 0 & - & 0 & 0 & 0 & 0 & 0 & 0 \\
\hline Sturgeon & - & - & - & - & - & 1 & 1 & 0 \\
\hline Kelp & - & - & - & - & - & - & 1 & - \\
\hline Cod & - & - & - & - & -0 & 5 & - & - \\
\hline Flounder & - & - & 0 & - & - & - & - & - \\
\hline Unspecified & - & - & - & - & - & - & - & 5 \\
\hline Eel & 2,011 & 1,822 & 1,670 & 1,729 & 1,636 & 1,729 & 1,699 & 1,532 \\
\hline Oyster & - & 0 & - & 0 & - & - & - & - \\
\hline Total & 37,762 & 42,919 & 39,549 & 37,652 & 42,438 & 42,637 & 41,886 & 39,297 \\
\hline
\end{tabular}

Source: Naturerhvervsstyrelsens akvakulturregister 3. Nov 2011 http://webfd.fd.dk/stat/

Akvakultur_tab/prod_art_10.html 
Aborre (Perch), Sandart (Pikeperch, Sander). Production has started based on a government research initiative in 2003-2006. Perch is now produced at one farm producing juveniles for export, while pikeperch is produced at three farms. All farms are using full recirculation systems. Production of pikeperch is expected to increase considerably as one company is investing heavily on this species.

Blåmusling (Blue mussels). Production is based on rope culture and smart farm systems. Production has increased for some years but recently decreased due to external competition leading to low prices.

Brødding (Arctic charr/Brook trout crossing), Fjeldørred/Rødding (Arctic charr),Kildeørred (Brook trout), Guldørred (Golden trout). Rainbow trout variety. Production mainly in traditional earthen ponds and used for restocking and put-and-take fishing and interesting "altenatives" to rainbow trout.

Havørred (Sea trout, Brown trout), Laks (Salmon). Mainly for restocking in danish rivers.

Pighvarre (Turbot). Production of juveniles for export to ongrowing. At present one major producer. Previously several attempts of establishing ongrowing.

Torsk (Cod). Expermental productions stopped due to too high summer temperatures.

Ål (Eel) Production gradually declining due to increasing difficulties in obtaining juveniles for stocking.

Regnbueørred (Rainbow trout). The traditional portion-size trout production in freshwater earthen ponds is partly being replaced or supplemented with seawater production of large rainbow trout and production in recirculation systems (Model trout farms type 1 and type 3, ecological produced trout).

Other species marginally produced includes Barramundi (Barramundi), Gedde (Pike), Guldbrasen (Sea bream) Helt (Whitefish, Coregonus), Karpe (Carp), Koi (Koi), Krebs (Freshwater crab), Malle (Catfish), Skrubbe (Flounder), Stør (Sturgeon), Sukkertang (Ulva), Tunge (Dover sole) and Østers (Oysters).

Table 2: Production 2010: Weight, Value 1000DKK), Value/kg.in DKK)

\begin{tabular}{lrrr}
\hline Species & Production (2010) Weight (t) & Value (kDKK) & DKK/kg \\
\hline Perch & 1 & - & - \\
Unspecified & 5 & - & - \\
Brown trout & 48 & 1,980 & 41.59 \\
Eel & 1,532 & 92,345 & 60.30 \\
Blue mussel & 669 & 3,047 & 4.55 \\
Arctic charr/Brook trout cross & 155 & - & - \\
Pike & 0 & - & - \\
Whitefish (Coregonus) & 0 & - & -
\end{tabular}




\begin{tabular}{lrrr} 
Brook trout & 115 & 3,095 & 26.93 \\
Salmon & 15 & - & - \\
Sea trout & 77 & 6,256 & 81.27 \\
Turbot & 6 & 2,964 & 525.37 \\
Rainbow trout & 32,500 & 628,818 & 19.35 \\
Pikeperch & 52 & 4,550 & 88.03 \\
Flounder & 0 & - & - \\
Sturgeon & 0 & - & - \\
Total & 37,175 & 735,251 & \\
\hline
\end{tabular}

Source: Naturerhvervsstyrelsens akvakulturregister 3. Nov 2011 http://webfd.fd.dk/stat/ Akvakultur_tab/prod_art_10_ex.html

The "Kilopris" value per kg., reflects the use of the varoius species. Bækørred, Havørred and Pighvarre are prices for juveniles used for restockings. Sandart is a luxury product while regnbueørred is a bulk, lowprice product.

\subsubsection{Industry structure}

The structure of Danish aquaculture is lines out in Table 3. We can see a large variation in size determined by gross output.

Table 3: Accounting reports 2010 to the Danmarks Statistik

\begin{tabular}{|c|c|c|c|c|c|c|}
\hline Farm type & & $\begin{array}{r}\text { Gross output in } \\
\text { tDKK 0-699 }\end{array}$ & $700-1.499$ & $1.500-2.499$ & $2.500+$ & Total \\
\hline \multirow[t]{2}{*}{ Trout farms, traditional } & Farms & 57 & 29 & 41 & 50 & 177 \\
\hline & Accounts & 18 & 9 & 23 & 39 & 89 \\
\hline Trout farms, re-circulated & Farms & - & 4 & 3 & 12 & 19 \\
\hline Model type 1 & Accounts & - & 1 & 2 & 7 & 10 \\
\hline Trout farms, re-circulated & Farms & - & - & - & 13 & 13 \\
\hline Model type 3 & Accounts & - & - & - & 12 & 12 \\
\hline \multirow[t]{2}{*}{ Sea farms } & Farms & 1 & - & - & 16 & 17 \\
\hline & Accounts & 1 & - & - & 14 & 15 \\
\hline \multirow[t]{2}{*}{ Eel farms } & Farms & - & - & - & 7 & 8 \\
\hline & Accounts & - & - & - & 3 & 4 \\
\hline \multirow[t]{2}{*}{ Shellfish farms } & Farms & 15 & 2 & - & - & 17 \\
\hline & Accounts & 2 & 1 & - & - & 3 \\
\hline \multirow[t]{2}{*}{ Other farms } & Farms & 2 & 1 & 2 & 1 & 6 \\
\hline & Accounts & - & 1 & 2 & 1 & 4 \\
\hline
\end{tabular}

Source: Regnskabsstatistik for akvakultur 2010, Danmarks Statistik, English summary

\section{Types of freshwater trout farms}

The traditional trout farm using earthen ponds is still the most common farm type, even though the count went down 6\% from 189 in 2009 to 
177 in 2010. Total production went down $26 \%$ from 22.980 metric tons in 2009 to 17.051 metric tons in 2010. In the traditional trout farm water is taken from rivers without active pumping. All farm have to use sedimentation basins to remove nutrients and particulate matter before reurning the water to the river. The main production is portion size fish (300-350g) for consumption and larger fish (ca. $1 \mathrm{~kg}$.) for ongrowing in sea-farms. During the last five year an increasing proportion of the production has been made in so-called "model fishfarms". Where the use of recirculation technology gives basis for a higher production without increasing environmental impact.

Model fish farm type 1 is extensive farms with mechanical water treatment and recirculation (max. $1.25 \mathrm{l}$ water/sec/tons feed/year). Water treatment is primarily sludge cones, filters and plant lagunes, but the use of biofilters is not required.

Model fish farms type 3 is intensive farms with a high degree of technology and low water exchange (max. $0.15 \mathrm{l}$ water/sec/tons feed/year). Fresh water is usully from ground water and intensive recirculation with mechanical and biologicals filters is used. Due to high investment and labour costs this type is used on large farms (min. 600 metric tons/year).

\section{Sea Farms}

In 2010 there were 17 sea farms distributed among 6 firms operating on 24 locations. Total production was 10,018 metric tons.

Sea farms are large circular nets kept floating using floating rings and anchored to the bottom. In Denmark they are exclusively used for production of large rainbow trout. Fish are stocked in the spring at a weight of $600-800 \mathrm{~g}$ and harvested in autumn at a weight of 3-5 kg. In recent years production of roe have had an increasing importance and now accounts for ca. $25 \%$ of total production value.

\section{Eel Farms}

In 2010 there were 8 eel farms distributed among 8 firms. Total production from eel farms was 1,325 metric tons. Eel farms are fully recirculated farms often in connection with traditional agriculture production. Production has in the last years suffered from lack of supply glass-eel for rectocking due to restrictions on fishing glass eels and export to asia leading to higher prices. In the period 2009 to 2010 production increased, however, with $14 \%$. 


\section{Shellfish farms}

Permissions for shellfish farming (blue mussels) has been issued from 2003 and in 201017 farm (45 licenses) were producing a total of 1,325 metric tons. Most of the production is in the Limfjord. Mussels are produced on longlines, either single drop-lines hanging vertical in the water or on continous lines. Compared to fished mussels, farm mussels have a higer meat content and therefore a higher price per. kg but price is still too low to provide an acceptable profitability.

\subsubsection{Employees}

The number of companies and employees in Danish aquaculture is shown in Table 4.

Table 4: Number of aquaculture companies and employees in Denmark.

\begin{tabular}{lccc}
\hline & $\mathbf{2 0 0 6}$ & $\mathbf{2 0 0 7}$ & $\mathbf{2 0 0 8}$ \\
\hline Number of companies & 189 & 178 & 162 \\
Employees & 726 & 733 & 730 \\
\hline
\end{tabular}

Source: Fiskeriets økonomi 2010, Fødevareøkonomisk Institut (ref. Danmarks Statistik)

The number of producers has been declining for a number of years due to closure of small producers and larger companies buying smaller companies. Total employment is therefore relatively constant.

\subsubsection{Geography}

The traditional earth pond rainbow trout production is located along major river systems. Production is therefore concentrated in the central and southern part of Jutland and there are very few farms North of the Limfjord, at Fünen, at Zealand and on adjacent islands. Industialized recirculation farms incl. eel farms are more ore less independent of location but taking advantage of the infrastructure used by the traditional production, and therefore located in the same areas. Mussels are primarily produced in the Limfjord. Sea farms are mainly located in the areas of the Great Belt, Little Belt and the Fünen Archipelago, where they can take advantage of relatively protected areas with high water exchange. 


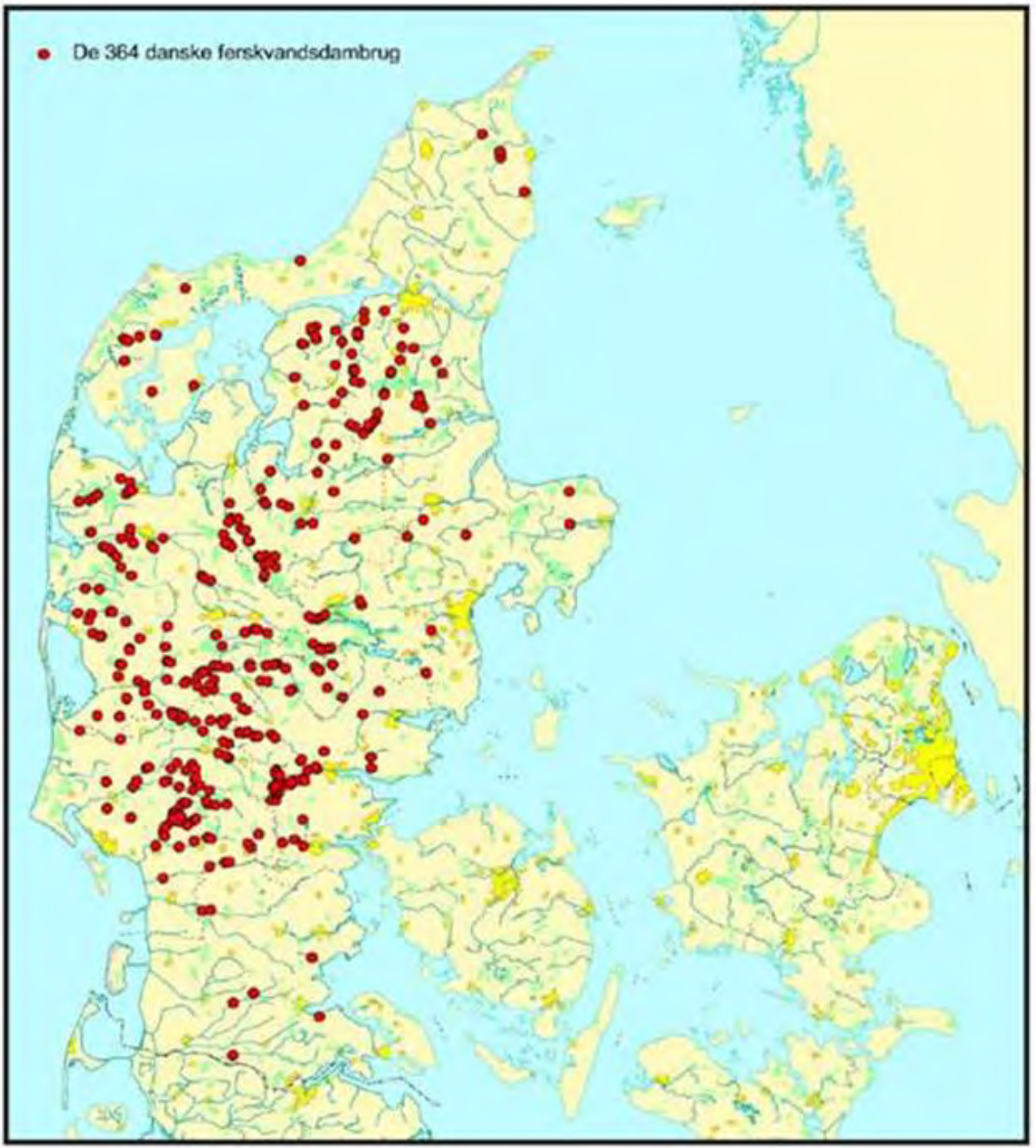

Sea-water aquaculture is primarily in the belts around the island of Fünen and in the fjords. Mussel culture is in the Limfjord area.

\subsubsection{Acts and regulations}

Aquaculture is in Denmark regulated by a large number of national and EU laws and directives, most of them having the overall aim to protect and the environment. Links to the law complex may be found at the homepages of:

- the Danish Aquaculture Producers Association

(http://www.danskakvakultur.dk/default.aspx?pageid=10) 
- the Ministry of Food, Agriculture and Fishery (http://www.fvm.dk/tilladelse_og_miljoegodkendelse.aspx?ID=14572)

- the Ministry of the Environment (http://www.naturstyrelsen.dk/)

- and the national law database (https://www.retsinformation.dk/)

Freshwater farms need an environmental approval according to:

- the Act on freshwater farms (Bekendtgørelse om ferskvandsdambrug - https://www.retsinformation.dk/Forms/R0710.aspx?id=12998)

- Models Fish Farms are approved according to the Act on Model Fish Farms Modeldambrug https://www.retsinformation.dk/Forms/R0710.aspx?id=13002

- Disposal of sludge is regulated through the Act on sludge (Slambekendtgørelsen https://www.retsinformation.dk/Forms/R0710.aspx?id=13056

- Intake of river water is controlled by the Act water intake from rivers (Bekendtgørelse om afgitring I ferske vande https://www.retsinformation.dk/Forms/R0710.aspx?id=8267

- the Law on water supply Vandforsyningsloven https://www.retsinformation.dk/Forms/R0710.aspx?id=127109

Sea water farms need approval according to the Act on establishment and running of seawater farms:

- (Bekendtgørelse om eatblering og drift af havbrug https://www.retsinformation.dk/Forms/R0710.aspx?id=77045)

- The use of feeds need aproval according to the order from the Ministry of Environments on approval of seawater based fishrearing. https://www.retsinformation.dk/Forms/R0710.aspx?id=12910

Eel farms and other productions in full recirculation do not need approval.

Production of mussels and shellfish on ropes need approval according to the Act on production on mussels etc. in the water column. (Bekendtgørelse om opdræt af muslinger m.m. I vandsøjlen https://www. retsinformation.dk/Forms/R0710.aspx?id=138324 
Perticularly one regulation on "feed quota" has had a high impact on the industry, and is considered to be one of the most important causes for the slow development. The "feed quota" system only provides an indirect control on the emission af nutrients to the environment and the system is therefore being replaced with regulations directly on the discharge. This will allow producers who can control nutrient emissions to increase their production. The "model fish farm" system is part of this process.

\section{Challenges of sustainability}

- Environmental sustainability. Traditional pond production is gradually being replaced with industrialised production based on recirculation technology.

- Consumer perception. "Organic" productions are introduced and restockings with reared eel elvers and other species are used to improve consumer image of the industy.

- Economic profitability. Investments in the aquaculture sector has been suffering from difficulties in obtaining bank financing due to low profitability. The profitability of particularly mussel culture has been negative in recent years.

\subsubsection{SWOT}

The Danish Ministry of Food, Agriculture and Fisheries has performed a SWOT analysis for the fisheries and Aquaculture sector in the report Operationelt program for udvikling af den danske fiskeri- og akvakultursektor 2007-2013. (Operational program for development of the Danish fishery- and aquaculture sector 2007-2013). The SWOT relevant particularly for aquaculture is summarised below. 


\begin{tabular}{|c|c|}
\hline Strengths & Weaknesses \\
\hline $\begin{array}{l}\text { Strong tradition of trout production } \\
\text { Training and competence in focus } \\
\text { High demand of products } \\
\text { High consiousness on quality } \\
\text { Good image of products } \\
\text { Environmental technology well developed } \\
\text { Leading I feed production } \\
\text { Global competence in equipment supply } \\
\text { Good geographical location }\end{array}$ & $\begin{array}{l}\text { Many small units } \\
\text { Long term planning difficult } \\
\text { High cost levels } \\
\text { Few education possibilities } \\
\text { Image in relation to environment and quality } \\
\text { Conflicts with local authorities }\end{array}$ \\
\hline Opportunities & Threats \\
\hline $\begin{array}{l}\text { Higher focus on quality } \\
\text { Training and education } \\
\text { Better logistics } \\
\text { Strategis alliances focusing on the whole value chain } \\
\text { Traceability } \\
\text { Better image in relation to environment and } \\
\text { sustainability } \\
\text { Development of environmental friendly technology } \\
\text { System exports eg. Clean technologies } \\
\text { New species } \\
\text { National legal systems favourable for long-term } \\
\text { planning } \\
\text { Better collaboration between research and industry } \\
\text { Higher level of processing at farms } \\
\text { Certification of production methods } \\
\text { Higher demands on products }\end{array}$ & $\begin{array}{l}\text { Relatively low level of education } \\
\text { Non-competitiveness on price and quality } \\
\text { Lack of labour force. Problems in recruitment and } \\
\text { generation shift } \\
\text { Environment critera that cannot be fulfilled } \\
\text { Economic financing }\end{array}$ \\
\hline
\end{tabular}




\subsection{The Faroe Islands}

\subsubsection{Species}

The Faroese aquaculture industry is marine based ${ }^{9}$ and has predominantly concentrated on production of Atlantic salmon and to a lesser degree rainbow trout.Production takes place in sea water floating cage systems. Faroese aquaculture started in the 1950's, but industrial production took off in the 1980 'ies. The production figures are shown in Table 1.

Table 1: Production in metric tons in Faroese aquaculture 1996-2011. (Faroese Bureau of Statistics)

\begin{tabular}{lrrr}
\hline & Salmon & Trout & Total \\
\hline 1996 & 14,484 & 824 & 15,307 \\
1997 & 16,651 & 1,296 & 17,947 \\
1998 & 15,724 & 1,134 & 16,858 \\
1999 & 32,187 & 2,963 & 35,149 \\
2000 & 27,477 & 1,184 & 28,660 \\
2001 & 37,731 & 2,813 & 40,545 \\
2002 & 36,861 & 10,034 & 46,896 \\
2003 & 43,071 & 9,198 & 52,269 \\
2004 & 33,608 & 4,583 & 38,190 \\
2005 & 15,549 & 4,044 & 19,593 \\
2006 & 10,728 & 4,934 & 15,662 \\
2007 & 18,290 & 6,883 & 25,173 \\
2008 & 31,565 & 6,707 & 38,272 \\
2009 & 42,134 & 6,488 & 48,622 \\
2010 & 37,221 & 1,791 & 39,012 \\
2011 & 49,588 & - & 49,588 \\
\hline
\end{tabular}

Figure 1: Faroese salmon production in value and weight 2008-2011. Source: http://salmon-from-the-faroe-islands.com 1

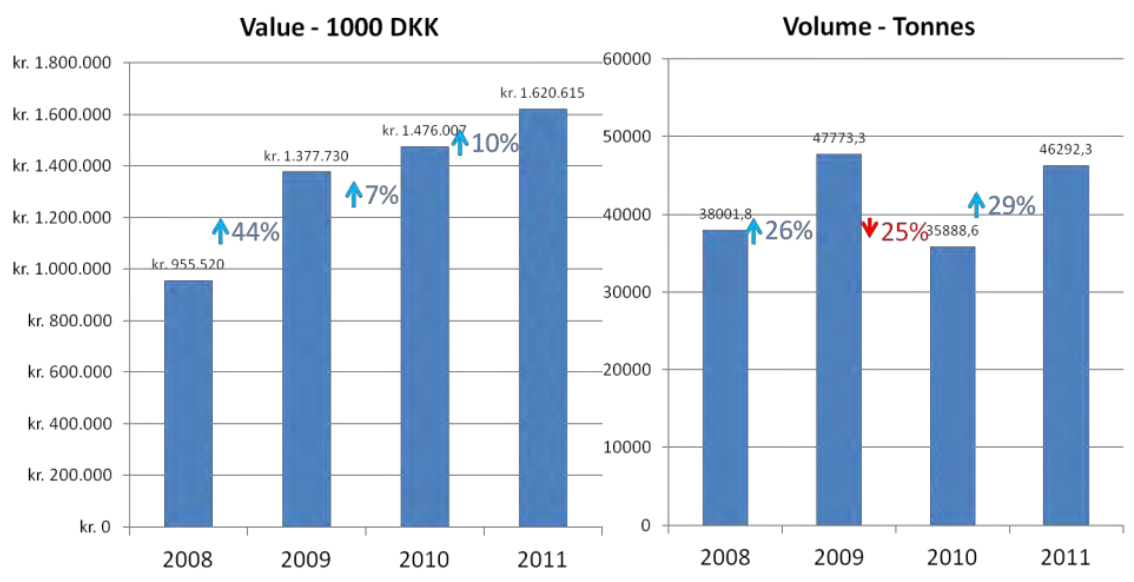

${ }_{9}$ The production of salmonid smolts is fresh water based 
Table 1. Export of different aquaproducts 2005 to 2011 (1.000 tonne)

\begin{tabular}{lrrrrrrrr}
\hline & $\mathbf{2 0 0 4}$ & $\mathbf{2 0 0 5}$ & $\mathbf{2 0 0 6}$ & $\mathbf{2 0 0 7}$ & $\mathbf{2 0 0 8}$ & $\mathbf{2 0 0 9}$ & $\mathbf{2 0 1 0}$ & $\mathbf{2 0 1 1}$ \\
\hline Fresh salmon & 23,312 & 9,330 & 4,514 & 10,347 & 22,681 & 28,489 & 21,541 & 35,350 \\
Frozen salmon & 3,509 & 2,374 & 1,073 & 2,087 & 1,598 & 2,587 & 1,778 & 747 \\
Salmon portions & 3,870 & 3,104 & 2,849 & 2,978 & 4,194 & 5,653 & 6,339 & 5,982 \\
Salmon, other & 479 & 736 & 1,131 & 1,400 & 3,280 & 3,835 & 4,037 & 3,977 \\
Fresh trout & 21 & 19 & 1,302 & 637 & 644 & 2,059 & 1,273 & 18 \\
Frozen trout & 3,607 & 2,802 & 2,302 & 3,864 & 5,598 & 4,970 & 779 & 219 \\
Tilsamans & 34,797 & 18,364 & 13,172 & 21,313 & 37,996 & 47,591 & 35,747 & 46,292 \\
\hline
\end{tabular}

Source: Statistics Faroe Islands

Table 2. Export value for different aquaproducts 2005 to 2011 (DKK 1.000)

\begin{tabular}{lrrrrrrr}
\hline & $\mathbf{2 0 0 5}$ & $\mathbf{2 0 0 6}$ & $\mathbf{2 0 0 7}$ & $\mathbf{2 0 0 8}$ & $\mathbf{2 0 0 9}$ & $\mathbf{2 0 1 0}$ & $\mathbf{2 0 1 1}$ \\
\hline Fresh salmon & 206,522 & 134,650 & 254,581 & 547,364 & 795,934 & 803,161 & $1,108,349$ \\
Frozen salmon & 53,660 & 32,573 & 55,274 & 40,826 & 68,587 & 69,508 & 26,508 \\
Salmon portions & 169,967 & 195,024 & 171,806 & 213,274 & 303,505 & 423,931 & 428,702 \\
Salmon, other & 9,703 & 12,074 & 11,000 & 22,956 & 34,703 & 41,456 & 48,332 \\
Fresh trout & 484 & 34,657 & 14,043 & 13,814 & 48,320 & 43,865 & 1,356 \\
Frozen trout & 58,190 & 64,034 & 86,730 & 124,731 & 123,149 & 24,851 & 7,368 \\
Trout, other & 0 & 168 & 0 & 73 & 3,613 & 1,238 & 0 \\
Total export value & 498,526 & 473,178 & 593,434 & 963,038 & $1,377,809$ & $1,408,009$ & $1,620,615$
\end{tabular}

Source: Statistics Faroe Islands

\subsubsection{Industry structure}

Fishery and aquaculture products comprise approximately $90 \%$ of the total export value of the Faroe Islands, and the share of aquaculture products has gone up significantly these past years and is now at app. one third of total export value. Production is almost exclusively salmon and rainbow trout ${ }^{10}$ produced in seawater floating cages. The Faroese fjords provide ideal conditions for this production with cool, clear waters in well protected areas. Aquaculture production started developing in the 1950's and gained momentum in the 1980's. . In the development phase excessive political involvement, which was driven by the fact that aquaculture was seen as a method of ensuring regional employment and rural development, meant that there were constraints on achieving efficient scale production. At one time in the 1980's there were more than 60 producers. In the period 2000 to 2005 the industry suffered from a number of disease outbreak leading to implementation of strict veterinary regimes making it possible for the industry to re-emerge. In recent

${ }^{10}$ Since 2010 only salmon has been farmed on the Faroe Islands 
years production has concentrated on still fewer companies and today only three companies are operating, Bakkafrost, Marine Harvest and HiddenFjord (Luna). Smolts are produced in land based freshwater farms using recirculation technology. In addition to the production of salmon and rainbow trout, two farmers are producing cod. The juveniles are produced at the Faroese Aquaculture Station. Experimental and research oriented cod productions has been done for a number of years, but commercial production is still in its infancy.

The potential for production of kelp and marine algae are presently being investigated.

\subsubsection{Employees}

According to Statistics Faroe Islands around 650 persons were employed in the aquaculture sector as full time equivalents. The number of employees has nearly doubled in the last 5 years. In comparison the total workforce in the Faroe Islands is app. 23,000 persons and the fisheries sector employs app. 2.800 persons.

\subsubsection{Geography}

Faroese aquaculture is currently made up of 22 sea-farms, 12 hatcheries and 3 broodstock production sites. The 22 sea-farms are located in fjords and bays offering an ideal combination of protection, water quality and access. The hatcheries and brood stock production sites are located on land. Processing plants are located by the coast. 
Figure 3: Location of sea-farms on the Faroe Islands

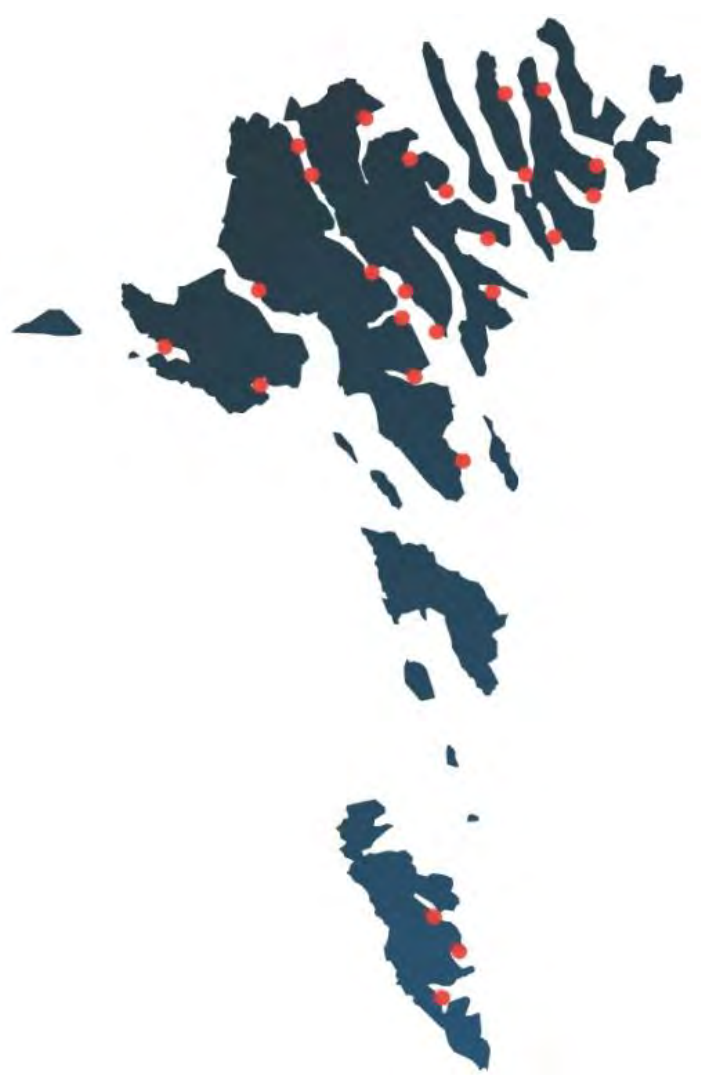

Source: Salmon.fo

\subsubsection{Acts and regulations}

Aquaculture on the Faroe Islands is regulated by these institutions:

- Ministry of Trade and Industry: Overall responsibility

- Food and Veterinary Agency: General administrative responsibility aquaculture licences, environmental and health issues, animal welfare and health, disease control.

- Environment Agency: Monitoring environmental effects of onfarming

- Office of Public Works: Permits to use fjords and inlets

- Ministry of Fisheries: Oversight and zoning of fjords 
Parliamentary Act No. 83 of May 25th 2009 on aquaculture (the Aquaculture Act). The Act is adminstered by the Ministry of Trade and Industry. The purpose of the Act is to establish a framework for sustainable development in the aquaculture industry and ensure competitiveness and profitability of the aquaculture industry. The Act specifies the conditions and requirements for the issue of a licence to conduct aquaculture.

Parliamentary Act No. 16 of February 23th 2001 on veterinary diseases (the Veterinary Disease Act), as amended by Parliamentary Act No. 18 of May 8th 2008. The Act is administered by the Faroese Food and Veterinary Authority and details the veterinary requirements that must be fulfilled if a licence to conduct aquaculture is to be issued in accordance with the Aquaculture Act. Pursuant to the Veterinary Disease Act, Executive Order No. 98 of June 8th 2003 on the transport of aquaculture animals, Executive Order No. 134 of July 16th 2009 on measures to combat certain aquaculture diseases and Executive Order No. 163 of December 21st 2009 on monitoring and prevention of sea lice in aquaculture animals.

Parliamentary Act No. 13 of October 29th 1988 on environmental protection as amended by Parliamentary Act No. 128 of December 22th 2008. The Act is administered by the Faroese Environment Agency. Pursuant to the Act, Executive Order No. 40 of April $9^{\text {th }} 1992$ on disposal of organic waste by the aquaculture industry, as amended by Executive Order No. 90 of September 28 ${ }^{\text {th }} 2007$, has been put into place. The Act and Executive specify the conditions and requirements for the issue of a licence to conduct aquaculture according to the Aquaculture Act. Specifically, Chapter 5 deals with polluting production (e.g. fish farming), which must have permission prior to commencement of activities.

Parliamentary Act No. 58 of May 26 2010 on production of food (the Food Act). The Act is administered by the Faroese Food and Veterinary Authority. Pursuant to the Aquaculture Act, the Food Act detail the conditions and requirements necessary for the granting of an aquaculture licence. Of particular importance is Chapter 8 on processing plants and Executive Order No. 114 of August 15th 2001 on internal control mechanisms, as amended by Executive Order No. 8 of February 5th 2003.

\section{Challenges of sustainability}

The intensive production in protected fiords and bays creates three major challenges.

Land allocation competition: Nearly all suited locations are today in use for production and future increase in production will probably be at open-water locations. 
Spreading of disease: Faroese veterinary regulations are amongst the most stringent in the aquaculture industry as disease outbreaks can quite easily spread as farming fjords are quite close to eachother.

Pollution from fish farms: Pollution is reduced by improved management and in the future relocation into more open areas.

\subsubsection{SWOT}

The SWOT analysis below is performed with assistance from the Faroese Ministry of Fisheries.

\begin{tabular}{|l|l|}
\hline Strengths & Weaknesses \\
\hline $\begin{array}{l}\text { Ideal environmental location for salmon } \\
\begin{array}{l}\text { Good image of products } \\
\text { Production leader Efficient laws and regulations } \\
\text { High level of training and competence } \\
\text { Good fish health and no use of antibiotics }\end{array}\end{array}$ & $\begin{array}{l}\text { Geographic isolation } \\
\text { Spatial constraints Salmon dependant } \\
\text { business }\end{array}$ \\
\hline $\begin{array}{l}\text { Opportunities } \\
\text { Improve utilization of areas and expand to furthest reaches of } \\
\text { fjords }\end{array}$ & $\begin{array}{l}\text { High cost economy } \\
\text { Improve transport and logistics } \\
\text { More value-added products and introduce new species } \\
\text { Utilize discharge for IMTA Expand to production areas at sea }\end{array}$ \\
\hline
\end{tabular}




\subsection{Iceland}

Aquaculture in Iceland involved mainly hatching of salmonids and restocking of rivers until 1950. In 1951 an era of small scale rearing of salmonids to slaughtering size began with rainbow trout. In the nineties, Icelandic scientist and farmers worked on developing aquaculture of species such as Atlantic halibut, turbot, abalone and Atlantic cod. From 2000 onwards, the main increase has occurred in the production of Atlantic salmon, Arctic char and Atlantic cod.

\subsubsection{Species}

Currently there are about 10 species of fish being farmed in Iceland. The production is dominated by Arctic char. Today Iceland is the world's largest producer of Arctic char with about $50 \%$ of total production (Figure 1). Companies owned by Samherji; Islandsbleikja, Islandslax and Silfurstjarnan are the biggest producers of Arctic charr in Iceland. Juvenile production is dominated by salmonid smolts and fry for ongrowing, released into various rivers and lakes, as well as for export. Fjarðalax has been permitted to produce 2,000 tonnes of salmon in Western fjords. The company has been gradually increasing their production and has applied for permits to cultivate more salmon. So have Arnarlax, Dýrfiskur and Hraðfrystihúsið Gunnvör as well.

The production of marine species is primarily Atlantic cod. The production of cod juveniles had been carried out on a research scale since 1994 and was stepped up in the beginning of 21st century. IceCod Ltd. is the only producer of cod juveniles and is expecting an increased production. A selective breeding program for cod farming was started by the company in 2003. First generation cod was selected in 2006 and the third generation is expected to be selected in 2012. Production of Senegal sole is furthermore planned in the coming years (Stolt Seafarm). Today 8 farms are on-growing wild or hatchery produced cod with Hraðfrystihúsið Gunnvör, the largest producer of farmed cod in Iceland (600 tonnes authorized), controlling the juvenile production, on-growing, harvesting, packaging and marketing of products. Capture of wild juveniles has been stopped and the last stocking in sea cages was performed in spring 2009. In addition most of the cod producers are as well ongrowing wild cod.

One Icelandic firm (Fiskey) has been successful in producing halibut juveniles, most of which are exported to Norway. Fiskey has been the largest individual producer of halibut juveniles on a global scale since 
1998 but the company filed for bankruptcy and stopped production in 2011. Several other species are also cultured in Iceland and new warmwater species have been imported in recent years. Tilapia was imported from Canada in 2008 and is now produced by Islensk Matorka ehf. The strategy is clear with focus on sustainable food production for export utilizing natural resources. The production is estimated to be $\sim 200$ tonnes in the year 2012, increasing to $4 \%$ out of at total of 5.000 tonnes produced in Icelandic aquaculture.

\subsubsection{Volumes}

Aquaculture production increased up to a maximum of 10,000 tonnes in 2006 with increased activity in salmon farming in sea cages (Table 1). In 2008 the production was around 5,000 tonnes. Currently there are approximately 10 species of fish being farmed in Iceland and the aquaculture production is around 5.000 tonnes. The production is dominated by Arctic char with Atlantic cod the leading marine species in the total production. Juvenile production in 2010 resulted in 70,000 Cod juveniles, 175,000 Halibut juveniles and 43,000 Turbot juveniles

Table 1. Aquaculture production in Iceland in tonnes of round fish. Currently Arctic charr represent $47 \%$ of the total production, Atlantic cod $35 \%$, Atlantic salmon $14 \%$ and other species (Rainbow trout, turbot, Atlantic halibut) 1-1.5\%. Chief Veterinary Officier

\begin{tabular}{lrrrrrrrrrr}
\hline Species & $\mathbf{2 0 0 2}$ & $\mathbf{2 0 0 3}$ & $\mathbf{2 0 0 4}$ & $\mathbf{2 0 0 5}$ & $\mathbf{2 0 0 6}$ & $\mathbf{2 0 0 7}$ & $\mathbf{2 0 0 8}$ & $\mathbf{2 0 0 9}$ & $\mathbf{2 0 1 0}$ & $\mathbf{2 0 1 1}$ \\
\hline Abalone & 23,6 & 6,5 & 1,5 & 4 & 0,4 & 0,5 & 0 & 0 & 0 & 0 \\
Arctic charr & 1,540 & 1,670 & 1,336 & 977 & 1,426 & 2,851 & 3,124 & 2,405 & 2,427 & 3,021 \\
Blue mussel & 0,5 & 4 & 5 & 5 & 7 & 10 & 10 & 49 & 32 & 46 \\
Cod & 205 & 393 & 595 & 1,050 & 1,412 & 1,467 & 1,502 & 1,805 & 1317 & 851 \\
Haddock & 0 & 65 & 0 & 0 & 23 & 23 & 4,5 & 0 & 0 & 0 \\
Halibut & 120 & 95 & 123 & 129 & 141 & 31 & 39 & 49 & 72 & 33 \\
Rainbow trout & 248 & 180 & 142 & 50 & 10 & 11 & 6 & 75 & 88 & 226 \\
Salmon & 1,471 & 3,710 & 6,020 & 6,094 & 6,894 & 1,158 & 292 & 714 & 1,068 & 1,083 \\
Sea Bass & 40 & 76 & 0 & 0 & 0 & 0 & 0 & 0 & 0 & 0 \\
Tiger shrimp & 0 & 0 & 0 & 0,1 & 0,2 & 0,3 & 0,3 & 0 & 0 & 0 \\
Tilapia & 0 & 0 & 0 & 0 & 0 & 0 & 0 & 0 & 0 & 2,5 \\
Turbot & 9 & 32 & 62 & 115 & 47 & 70 & 51 & 68 & 46 & 20 \\
Total & 3,657 & 6,231 & 8,284 & 8,424 & 9,961 & 5,622 & 5,029 & 5,165 & 5,050 & 5,283 \\
\hline
\end{tabular}

The salmon farming in Iceland is significantly recovering and the Arctic char production is also expected to increase in line with the increasing number of farms. Given the current plans of increasing production of salmon, arctic charr and sole cultivation, it can be assumed that the increase in the aquaculture production could be around 25 thousand tons over the next 5-7 years, valued at 18-20 billion at current market prices. 


\subsubsection{Value}

In 2010 , the 5,000 tonnes produced in aquaculture returned a total value of 4 billion ISK. One Icelandic company, Stofnfiskur, has specialized in selective breeding of salmon and export of eggs to other countries.Arcti $\mathrm{c}$ char is either sold from Iceland as gutted with the head on or as fully trimmed fillets fresh or frozen. Most of the Iceland Arctic charr produced is filleted and exported by air to several countries in Europe and North America. The largest markets for Iceland Arctic charr by volume are the United States and Switzerland.

\subsubsection{Facilities}

There are 68 authorized facilities that have been permitted to cultivate aquatic species in Iceland, thereof 35 sites are not allowed to produce more than 10 tonnes annually. Cultivation is furthermore prohibited in defined areas (Figure 3). A total of 11 facilities have been granted permission to produce 150 tonnes or more, whereof 28 are producing juveniles, primarily salmonid (14) for releases (Figure 2). Total workforce within the aquaculture sector was $\sim 200$ employees in 2008 (see Table 2). Of the 68 authorized facilities for cultivation, 44 facilities are operated in the purpose of production of fish for human consumption. Blue mussel is cultivated by 10 companies, with Skelfélagið located in Hrísey as the largest one with 30 tonnes allowed, followed by Vesturskel with the production of 10 tonnes and the rest are allowed to produce up to 5 tonnes.

In 20095 facilities were responsible for producing $77 \%$ of the annual aquaculture production and the 10 largest producers produced $92 \%$ of the total production. In 2012 there were 11 sea cage farms, thereof seven producing cod, two producing salmon, one producing Rainbow trout and one producing salmon and arctic charr. In early 2012, there are 13 land-based farms producing arctic charr, there of one in combination with rainbow trout production, one farm in combination with tilapia and one farm in combination with salmon, turbot and halibut. One company is authorized to produce sea cucumber and abalone. In addition to the previously mentioned activities, production of Sole Senegalese's is planned to start in year 2013 by one company. 
Table 2. Work force in Icelandic aquaculture in 2008

\begin{tabular}{lrrrrrr}
$\begin{array}{l}\text { Company } \\
\text { activity }\end{array}$ & $\begin{array}{r}\text { No. of } \\
\text { companies }\end{array}$ & $\begin{array}{r}\text { Companies } \\
\text { with <10 } \\
\text { employees }\end{array}$ & $\begin{array}{r}\text { Companies } \\
\text { with 10-49 } \\
\text { employees }\end{array}$ & $\begin{array}{r}\text { Total No. of } \\
\text { employees }\end{array}$ & $\begin{array}{r}\text { No. of employee } \\
\text { with <10 } \\
\text { employees }\end{array}$ & $\begin{array}{r}\text { No. of employee } \\
\text { with 10-49 } \\
\text { employees }\end{array}$ \\
\hline Sea cages & 10 & 9 & 1 & 43 & 32 & 11 \\
Land based & 18 & 14 & 4 & 147 & 48 & 99 \\
Total & 28 & 23 & 5 & 190 & 80 & 110 \\
\hline
\end{tabular}

Figure 2. Geographical distribution of aquaculture units in celand by farm types (2010). Gísli Jónsson. 2010. Miðlun til fiskeldismanna. Ráðstefna og vinnufundur Landssambands fiskeldisstöðva, Hólum í Hjaltadal 13 and 14 October 2010

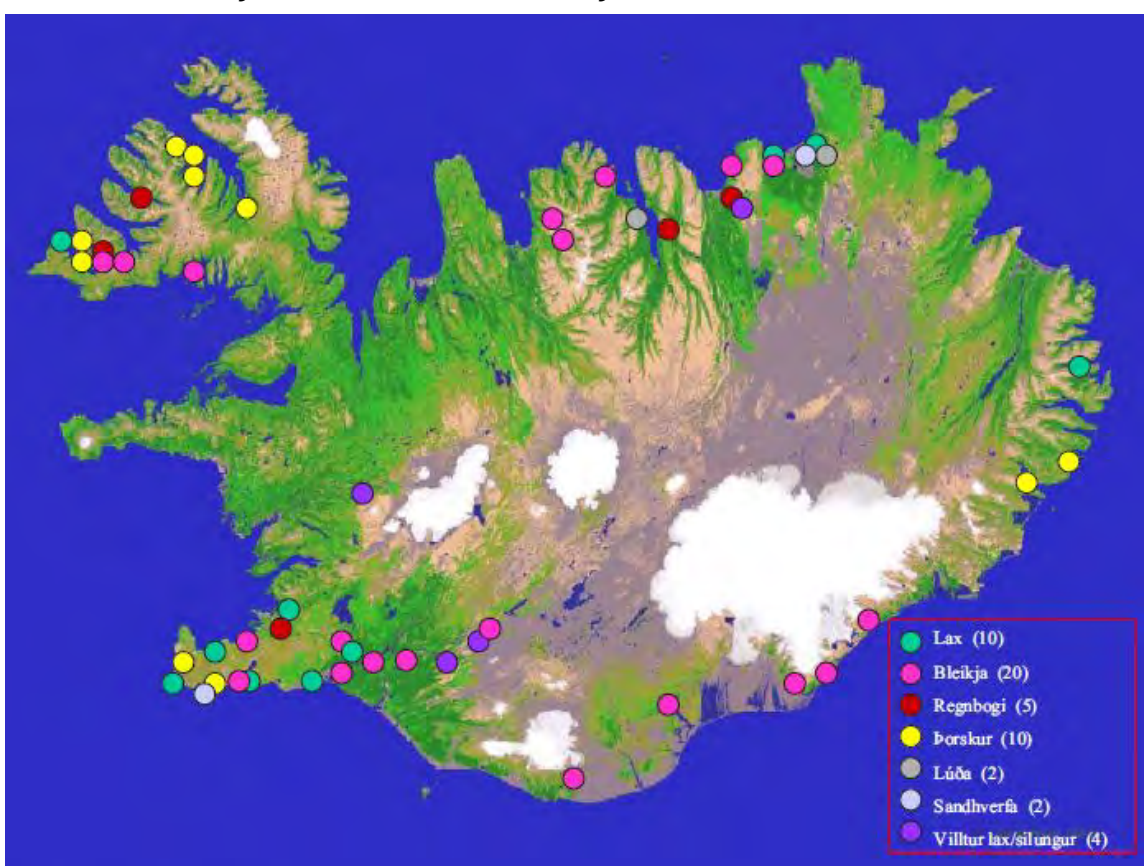


Figure 3. Protected areas where cultivation of fertile salmon is prohibited. Arni Isaksson at NASCO 2004. NASCO CNL(04)32

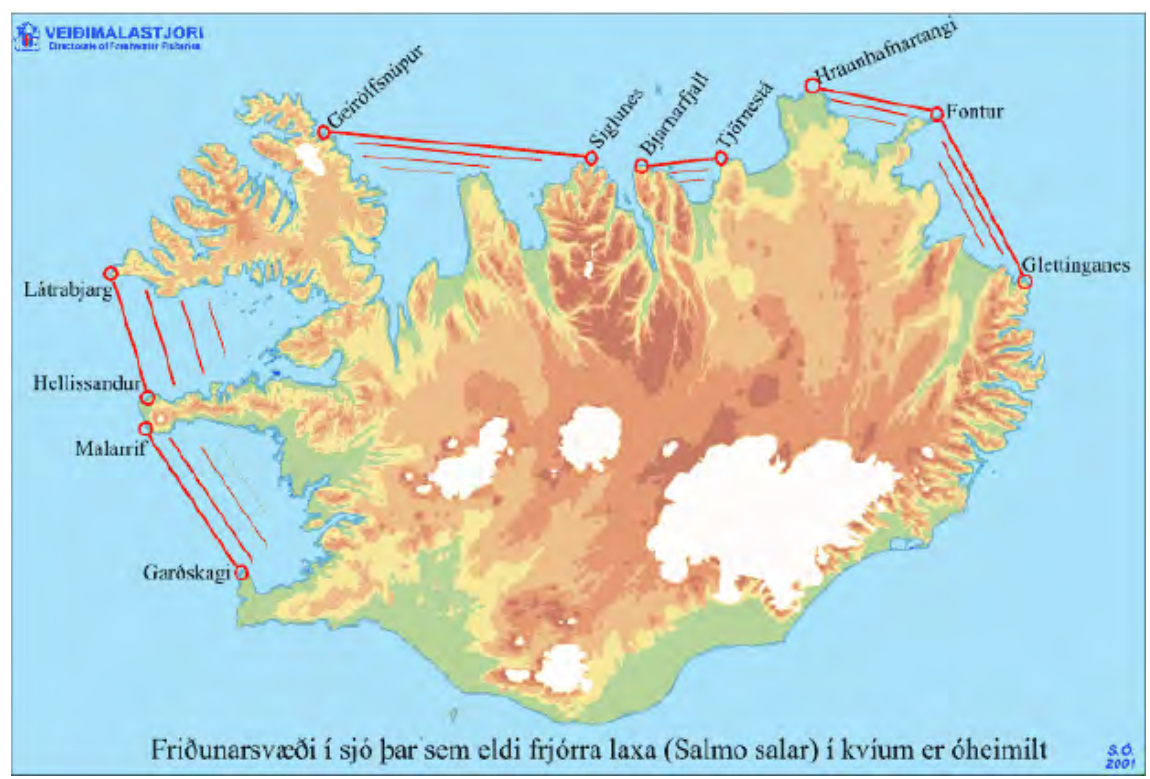

\subsubsection{Acts and regulations}

In order to start up an aquaculture facility, a licence issued by Icelandic Food and Veterinary Authority is required. Currently each facility needs to fulfil requirements set out by the Directorate of Fisheries, the Icelandic Food and Veterinary Authority, the Environmental Agency, the Icelandic National Planning Agency and the local Health Inspection, prior to cultivation of aquatic species. Ten different Acts and 16 regulations deal with aquaculture in Iceland, whereof 10 are based on European regulations.

The Acts address with fish diseases and protection against diseases, animal protection, import of animals, processing of seafood products, catching of salmonids, growing fish and cultivation of aquatic species. The oldest valid Act is Act 50/1986 on research department of fish diseases. More recent are Acts 58/2006, 60/2006 and 71/2008 on growing fish, protection against fish diseases and aquaculture.

Regulation $238 / 2003$ on cultivation of marine species is being reviewed as a new regulation on aquaculture as a whole and is being drafted by the Ministry of Fisheries and Agriculture. The most recent regulation in Icelandic Aquaculture is Regulation 1043/2011 on inspection of the health of cultivated animals and animal products in accordance regulations in the European Economic Area. 


\section{Challenges of sustainability}

\begin{tabular}{|c|c|}
\hline Strength & Opportunities \\
\hline $\begin{array}{l}\text { Warm and cold water resources } \\
\text { Successful breeding plan of Arctic charr and Atlantic } \\
\text { salmon } \\
\text { Good potential for sea farming in the Westfjords } \\
\text { Human resources and knowledge (production and } \\
\text { processing) } \\
\text { Technological expertise } \\
\text { Absence of most of serious diseases }\end{array}$ & $\begin{array}{l}\text { Create jobs in rural areas } \\
\text { Utilization of geothermal energy } \\
\text { Rapid growth in the production of Salmon and Arctic } \\
\text { charr } \\
\text { Possibilities to optimise favourable and stable envi- } \\
\text { ronmental conditions } \\
\text { Emphasis on locally produced foods } \\
\text { Synergetic effects with sports fishing } \\
\text { Exploitation of new technologies } \\
\text { Increased general health awareness } \\
\text { Possibilities to lower the production costs } \\
\text { Utilization of by-products }\end{array}$ \\
\hline Weaknesses & Threats \\
\hline $\begin{array}{l}\text { Simplicity of production } \\
\text { Limited recruitment } \\
\text { Lack of utilization of by products } \\
\text { Lack of effective vaccines } \\
\text { Fluctuating market prices }\end{array}$ & $\begin{array}{l}\text { Competition (mainly from Norway) } \\
\text { Public resistance } \\
\text { Environmental degradation (diseases and spread of } \\
\text { unwanted genes) } \\
\text { Changed consumer behaviour } \\
\text { High production costs } \\
\text { Disease threats } \\
\text { The economic situation }\end{array}$ \\
\hline
\end{tabular}




\section{Perspectives for sustainable development of Nordic aquaculture}

Aquaculture is one of the fastest growing productions and the value of aquaculture is now about to pass the value of capture fisheries. Among the Nordic countries, Norway in particular has been able to create a large aquaculture industry with high growth rates over a number of years. The other Nordic countries have only had limited growth, but have a high unutilised potential. There is a need to identify opportunities and limitations for increased growth with due care for sustainability and environment. This report identifies seven focus areas with special potential for creation of a sustainable, competitive Nordic aquaculture sector. These areas are new feeds, better use and reuse of nutrients (nitrogen, phosphorus and carbon), value adding of by-products, technological and regional development, domestication of new species and reduction of energy consumption. The aquaculture sector with its strengths and weaknesses is described for each of the Nordic countries.

The report is compiled on basis of contributions from a Nordic group of experts. It was presented at a seminar on Green Growth at the annual meeting of the Nordic Ministers of Fisheries in Trondheim, July 2012.

TemaNord 2013:546

ISBN 978-92-893-2571-4

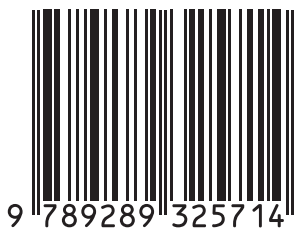

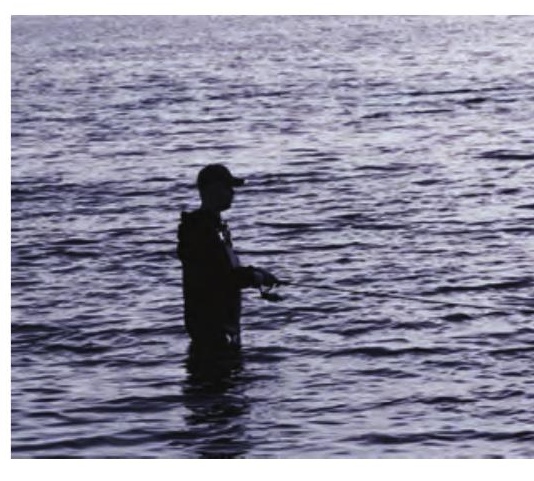

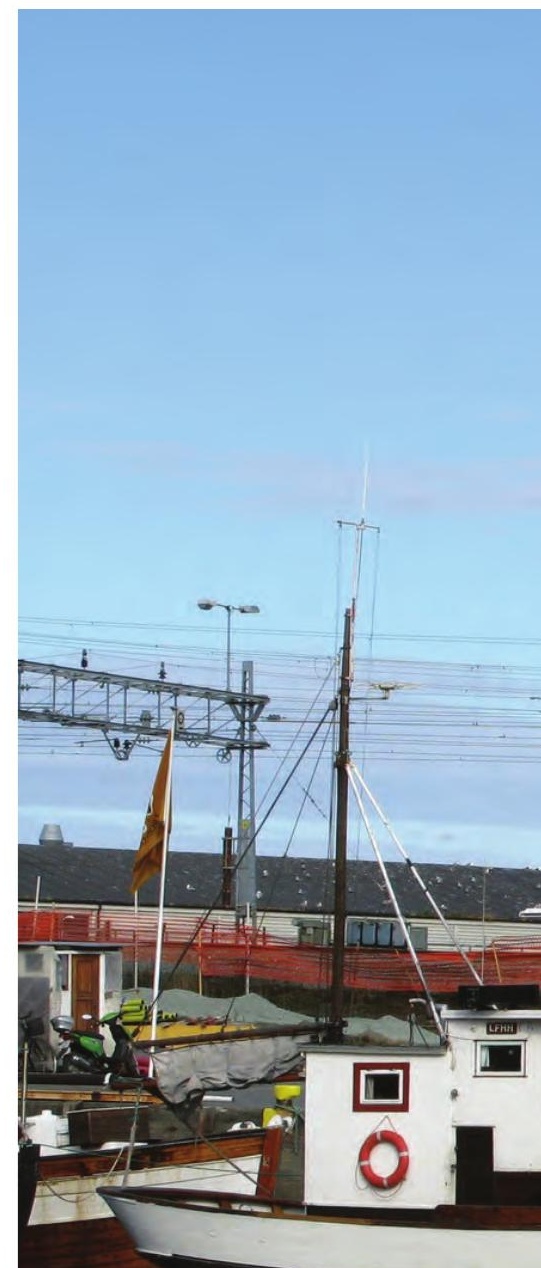

